\title{
OLHARES ENTRECRUZADOS: mulheres em situação de rua na cidade de São Paulo
}

GISELE APARECIDA DIAS FRANCO ARRUNÁTEGUI

Tese apresentada ao Programa de PósGraduação em Saúde Pública para obtenção do título de Doutor em Saúde Pública.

Área de Concentração: Saúde Materno-Infantil Orientadora: Augusta Thereza de Alvarenga

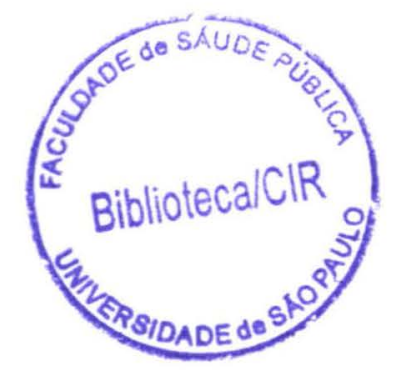

São Paulo

2008 


$$
4979+12008 \text { doe }
$$

É expressamente proibida a comercialização deste documento tanto na sua forma impressa como eletrônica. Sua reprodução total ou parcial é permitida exclusivamente para fins acadêmicos e científicos, desde que na reprodução figure a identificação do autor, título, instituição e ano da tese. 
Dedico este trabalho àqueles que me ensinam a viver e dos quais eu me considero uma eterna devedora:

Aos amados Mestres Ragiv e Jesus Sant'ana que com tanto amor têm se dedicado a abrir nossos olhos...

A Tajra (Cenir Bronetti Sant'ana) de olhos sábios e compassivos nos quais minha alma se encanta e se inspira;

A Mimi e Matilde, cujos olhos misericordiosos eu nunca esquecerei;

A meus pais, Charam (Esmeraldo) e Gandhary (Maryvone), que com olhos amorosos me acolheram em seu ninho;

Ao meu filho Gabriel que traz no azul do olhar a beleza da vida;

Ao Gino, de olhos negros, pelos quais me apaixonei há muito tempo.... 
Agradecimentos

A Fapesp que financiou este trabalho

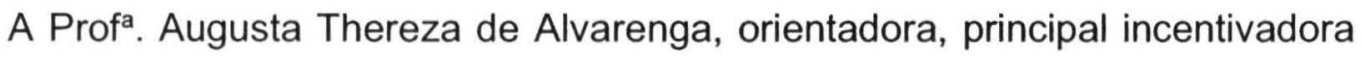
deste trabalho e para a qual eu jamais conseguiria, com o universo limitado das palavras, agradecer o suficiente, expressar meu carinho e minha admiração. Nesses anos de convívio com Augusta, pude presenciar verdadeiras lições de grandeza moral e intelectual, travestidas de humildade.

A Aparecida Magali de Souza Alvarez, pela amizade sincera, pelo companheirismo, sustentação constante, respeito e dedicação com que leu este trabalho.

A Maria Antonieta Vieira que presente desde a qualificação, acompanhou e colaborou ativamente para que este trabalho se concretizasse.

Ao Prof. Rubens do Camargo Adorno, pela disponibilidade, pelas sugestões e pela generosidade sempre presentes no decorrer deste doutorado.

A Prof ${ }^{a}$ Wilza Vieira Villela pela leitura cuidadosa deste texto e sugestões instigantes apresentadas.

Ao Prof. Alberto Olavo Advíncula Reis pelas inúmeras intervenções quando momentos árduos tornaram-se leves.

A lara Macedo e Leandro Cleto pelo carinho e dedicação nas muitas vezes em que estiveram sempre disponíveis para me ajudar na caminhada...

Ao Laércio Fidelis, Luciane Haupp, Beatriz Rudge e equipe da EP Escritório de pesquisa pela realização do trabalho de campo. 
Aos meus "irmãos": Paula Simonetti, Gabriela Simonetti, André Dias e Sandra Renata Dias!!!!

Ao Michel Dias... "óme bão" esse aí !

A Ravanara (Leila Kassab) e Pitry (Jacqueline Paggioro), amigas de fé, irmãs, camaradas...

A Suryananda (Salwa Kassab), Vulcan (Marcelo Ribeiro), Seybi (Valéria Farhat), Aghnys (Silvia Hiraoka), Shiraz (Rubianne Medrano), Kosaly (Maria Aparecida Scali) e todos os amigos do núcleo Prakriti Capão Bonito pelo apoio, carinho e compreensão.

Ao André Lencioni que fala sempre as palavras certas, na medida certa, na hora certa, no tom certo!!!!

A Profa ${ }^{a}$ Rita de Cássia Milani Miranda, uma leitora atenta e interessada, apaixonada pelo mundo das letras e das idéias que carinhosamente revisou este trabalho.

A Enlil (Heloísa Arrunátegui), serrana das "Minas Geraes", com quem eu sempre pude compartilhar os bons e os maus momentos!

A Ruth de Souza que me fez descobrir, nesses 18 anos de amizade incondicional, que a selva de pedra escondia um coração...

Ao Moacir de Souza e Amélia de Souza: do longo verbete que ocupam no meu dicionário espiritual, posso destacar "1. almas nobres, presentes da vida para mim, com quem tenho a certeza de poder contar. 2. amizade, fraternidade e amor sincero..." 
A Ana Flávia Ozi Dias que nos ensinou em seus dois anos vividos o significado de coragem, doçura e fé ...

A Antonia Eleni Araújo, pelo apoio "logístico".

A todas as tias-mães da família Mimi Dias: minha madra Dayalin (Maria Lúcia), Vitharka (Marlene), Shankara (Cléo), Vindhia (Regina), Samarcan (Vera) e Sandra, as quais têm me ensinado a acreditar em deuses, em sonhos e em mim... 
"Quem não compreende um olhar, tampouco compreenderá uma longa explicação"

Mario Quintana 
ARRUNÁTEGUI GADF. OLHARES ENTRECRUZADOS: mulheres em situação de rua na cidade de São Paulo [Tese de Doutorado]. São Paulo: Faculdade de Saúde Pública da USP; 2008.

\begin{abstract}
Resumo
Nos últimos anos tem-se observado contínuo aumento do contingente de pessoas em situação de rua, especialmente em grandes cidades como São Paulo. Na literatura disponível sobre o tema não se ressalta, no entanto, a particularidade do grupo feminino vivendo nas ruas, como um segmento peculiar com necessidades específicas, além das enumeradas pelo discurso médico predominante na área da saúde. O presente trabalho tem como objetivos: compreender a experiência de a mulher morar na rua pelo olhar das mesmas, assim como pelos olhares do Outro Próximo - homens em situação de rua - e do Outro Distante - constituído por um grupo diversificado de não moradores de rua; identificar questões de gênero emergentes nas falas dos entrevistados sobre mulheres em situação de rua cruzando os diferentes olhares sobre as mesmas. A investigação empírica, de natureza qualitativa, apoiou-se em entrevistas em profundidade, a partir de roteiros temáticos específicos para cada um dos três grupos considerados: Grupo 1 Mulheres em situação de rua; Grupo 2 - O Outro Próximo: homens moradores de rua e Grupo 3 - O Outro Distante: homens e mulheres não moradores de rua. AS narrativas foram interpretadas como discursos significativos, à luz de teorias das ciências sociais, contemplada a abordagem de gênero. Ao se cruzar os olhares dos três grupos, tais discursos revelam um modo de vida caracterizado pela diversidade de sujeitos e especificidades em que o "Nós" e os "Outros" ora se contrapõem, ora se aproximam, em uma dinâmica própria. O mundo da rua apresenta-se como um mundo de regras predominantemente masculinas, em que relações de poder se instauram em diferentes niveis nas relações sociais entre homens e mulheres, dentre elas as de gênero, que conservam, de maneira acentuada, resquícios da ordem patriarcal ainda presentes na realidade brasileira.
\end{abstract}

Descritores: população em situação de rua, mulher em situação de rua; exclusão social; gênero; violência de gênero. 
ARRUNATEGUI GADF. INTERTWINED LOOKS: homeless women living in the city of São Paulo [Doctor degree Thesis]. São Paulo city: School of Public Health, University of Săo Paulo, 2008

\begin{abstract}
A growing increase of homeless people has been noticed, during the last few years, especially in big cities such as Sao Paulo. Yet the available scientific literature on the theme does not stress the particularity of the feminine group of homeless, as a peculiar segment with specific needs, beyond the requirements specified by the medical speech, which prevails in the health domain. The purposes of the current work are: to understand the experience of homeless women through their personal look, as well as through the look of the Other Individual Close to Them - homeless men - and the Other Individual Far Away from Them - composed by a diversified group of people that are not homeless; to identify gender issues noticed during the speeches of the interviewee about homeless women and intersect the different views about them. The empirical research, of qualitative nature, was based on depth interviews, according to specific thematic programs for each one of three respective groups: Group 1 - Homeless Women; Group 2 - The Other Individual Close to them: Homeless Men; and Group 3 - The Other Individual Far Away from Them: Men and women who are not homeless. The narratives were interpreted as significant speeches, enlightened by the Social Sciences theories, considering the gender approach. By interlacing the views of the three groups, such speeches reveal a way of life characterized by the subjects and specifications diversity where the "Us" and the "Others" are either opposed, or approached, in a particular dynamics. The street world presents itself as a world full of mannish rules where the power relations are established in different levels of social relationships amid men and women, among them, gender relationships which emphatically preserve traces of the patriarchal order still alive in the brazilian reality.
\end{abstract}

Keywords: homeless population, homeless women, social exclusion; gender; violence of gender. 
ARRUNATEGUI GADF. INTERTWINED LOOKS: homeless women living in the city of São Paulo [Doctor degree Thesis]. São Paulo city: School of Public Health, University of São Paulo, 2008

\begin{abstract}
A growing increase of homeless people has been noticed, during the last few years, especially in big cities such as Sao Paulo. Yet the available scientific literature on the theme does not stress the particularity of the feminine group of homeless, as a peculiar segment with specific needs, beyond the requirements specified by the medical speech, which prevails in the health domain. The purposes of the current work are: to understand the experience of homeless women through their personal look, as well as through the look of the Other Individual Close to Them - homeless men - and the Other Individual Far Away from Them - composed by a diversified group of people that are not homeless; to identify gender issues noticed during the speeches of the interviewee about homeless women and intersect the different views about them. The empirical research, of qualitative nature, was based on depth interviews, according to specific thematic programs for each one of three respective groups: Group 1 - Homeless Women; Group 2 - The Other Individual Close to them: Homeless Men; and Group 3 - The Other Individual Far Away from Them: Men and women who are not homeless. The narratives were interpreted as significant speeches, enlightened by the Social Sciences theories, considering the gender approach. By interlacing the views of the three groups, such speeches reveal a way of life characterized by the subjects and specifications diversity where the "Us" and the "Others" are either opposed, or approached, in a particular dynamics. The street world presents itself as a world full of mannish rules where the power relations are established in different levels of social relationships amid men and women, among them, gender relationships which emphatically preserve traces of the patriarchal order still alive in the brazilian reality.
\end{abstract}

Keywords: homeless population, homeless women, social exclusion; gender; violence of gender. 


\section{ÍNDICE}

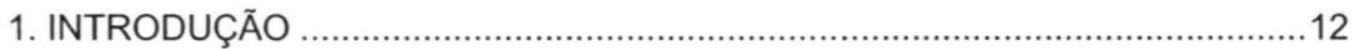

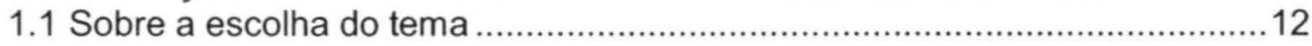

1.2 Faces e interfaces do morar na rua na cidade de São Paulo .........................14

1.2.1 Globalização e exclusão na cidade de São Paulo ..................................14

1.2.2 Caracterização sócio-demográfica da população de rua ......................20

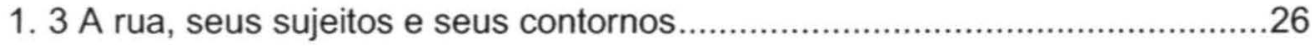

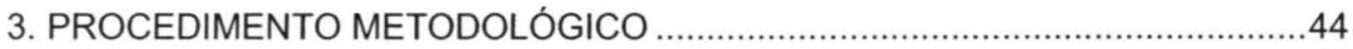

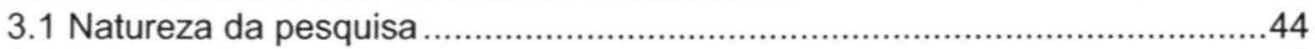

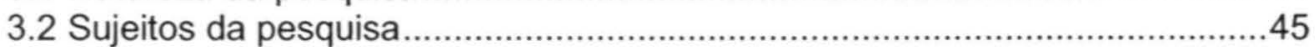

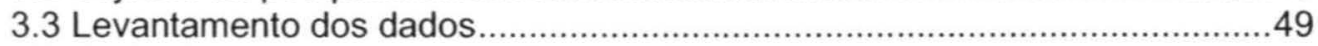

3.4 Tratamento e interpretação das narrativas..................................................52

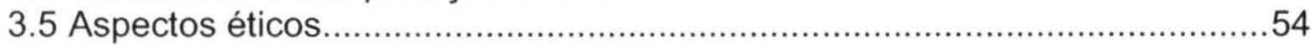

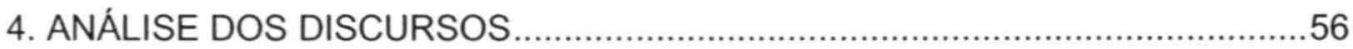

4.1 Retratos de mulheres em situação de rua..................................................56

$4.2 \mathrm{O}$ olhar do Outro Distante sobre mulheres em situação de rua .....................85

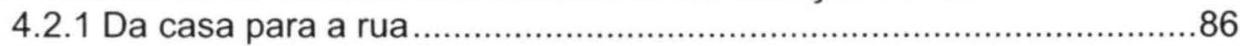

4.2.2 Ser homem e ser mulher em situação de rua ......................................97

4.2.3 Relações de gênero na perspectiva do Outro Distante ........................114

4.2.4 Da rua para a casa: um caminho possível? ....................................120

4.3 O olhar dos homens - o Outro Próximo- sobre mulheres em situação de rua

4.3.1 Da casa para a rua.......................................................................125

4.3.2 Ser mulher e ser homem em situação de rua na perspectiva do Outro Próximo.

4.3.3 Relações sociais no mundo da rua e a transversalidade de gênero. 142

(1) Relações sociais de gênero....................................................................142

(2) Relações conjugais, afetivas e sexuais no mundo da rua..............................151

(3) O lugar da mulher no cenário do mundo da rua ..........................................160

4.3.4 Da rua para a casa: um retorno possível? ......................................... 164

4.4 O olhar das mulheres em situação de rua sobre si mesmas .......................166

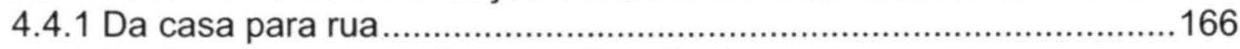

4.4.2 Ser homem e ser mulher em situação de rua ................................... 173

4.4.3 Relações sociais no mundo da rua e a transversalidade de gênero. 188

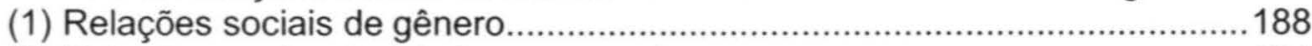

(2) Relações conjugais, afetivas e sexuais ...................................................191

(3) Albergues: entre a rua e a casa ? ..............................................................196

4.4.4 Da rua para casa: um sonho possivel? .............................................204 
5. CRUZANDO OLHARES, ABRINDO QUESTÕES.

6. REFERÊNCIAS

Anexos

1 Roteiros temáticos: Grupo 1, Grupo 2 e Grupo 3

2 Anotações de Campo

3 Termo de consentimento livre e esclarecido 


\section{INTRODUÇÃO}

\subsection{Sobre a escolha do tema}

Por que alguém se dedica a determinado problema de pesquisa e o persegue, às vezes, por toda sua vida? Que motivações animam o pesquisador ao selecionar seu objeto?

Um recuo no tempo torna-se necessário quando eu, nos anos 1990, participava do "grupo da sopa", entidade filantrópica que levava alimento a grupos de moradores de rua, nas regiões centrais da cidade de São Paulo.

Semanalmente, por três horas, mergulhávamos em um mundo paralelo: tão perto geograficamente e tão longe, no que tange a nossa experiência vivida. Eram seres humanos como nós, moradores da mesma cidade, ocupando espaços territoriais contíguos, mas que se afiguravam desumanizados, despidos de cidadania, de condições mínimas para existirem como sujeitos de direito.

Amontoados em postos de gasolina, escondidos em "cavernas" forjadas no concreto de viadutos, caídos no chão, embriagados, enlouquecidos... Assemelhavam-se a náufragos, mas lançados em mar de asfalto. Homens, mulheres sozinhas ou com seus filhos...Cada um com sua trajetória de vida...

Chamava-me atenção, de modo especial, o caso das mulheres. Algumas na calçada nos convidavam a sentar em caixotes improvisados "sofás da sala", como faziam questão de dizer -, outras queriam, nos dias de frio, compartilhar conosco o calor da fogueira improvisada. Ninavam seus 
filhos ao som das sirenes e buzinas... Dormiam em "camas de casal" demarcadas no chão com papelão. Havia ali configurado fenômeno de múltiplas redes, formas de sociabilidade, conflitos, arranjos de sobrevivência.

Desafiava-me, sobremaneira, tal complexidade a ponto, de tempos depois, encontrar-me aqui ainda em busca de respostas. Esse caminho, no entanto, não foi percorrido de maneira linear, muito embora a preocupação com o papel social desempenhado pela mulher, no contexto religioso do Mediterrâneo Antigo, tenha marcado o mestrado, realizado no Museu de Arqueologia da Universidade de São Paulo (MAE/USP) e concluído em 2002.

Assim, depois de um longo período debruçada sobre a Antiguidade Clássica, no ano de 2003, chamada por Aparecida Magali de Souza Alvarez para participar de seu projeto de pós-doutorado - pesquisa-formação-ação com apoio Fapesp - intitulado "Psico-sócio-formação de pessoas envolvidas com a questão do morador de rua”, na Faculdade de Saúde Pública/ USP, eu fui "capturada pelo fenômeno" - como diria a própria Magali - do viver na rua, deixando para trás as mulheres e deusas gregas, como objeto de estudo, e mergulhando no universo de mulheres em situação de rua.

O convite para a reflexão me foi oferecido pelo arcabouço teórico das Ciências Sociais que permitiram a junção de meu ideal humanista com o conhecimento cientifico.

Eis aqui a pesquisa que apresenta a proposta investigativa decorrente do meu encontro com o mundo das mulheres em situação de rua, 
visto agora "de perto e de dentro", numa outra forma de solidariedade: a acadêmica.

\subsection{Faces e interfaces do morar na rua na cidade de São Paulo}

\subsubsection{Globalização e exclusão na cidade de São Paulo}

No final do século $X X$, com o desenvolvimento intensivo e extensivo do capitalismo emerge, no contexto mundial, uma configuração geo-histórica original, dotada de peculiaridades e movimentos próprios, que foi denominada globalização. Trata-se de um processo de diminuição dos constrangimentos geográficos sobre as realidades social, econômica, política e cultural, as quais passam a ser consideradas no âmbito transnacional. Tal fenômeno é apontado por Magnani, principalmente a partir da década de 1980, com a identificação de seu impacto sobre as grandes metrópoles, transformadas em "cidades globais". Essal denominação, segundo Magnani, alude ao papel que algumas cidades ocupam numa economia altamente interdependente: sedes de conglomerados multinacionais, pólos de instituições financeiras, produtoras e/ou distribuidoras de determinados serviços, informações e imagens, elas constituem os nós da ampla rede que também já é conhecida, num mundo globalizado, como "sistema mundial" (Magnani, 2002:12).

O espaço territorial urbano surge, portanto, como palco em que se dá a efervescência de diferentes povos e culturas, língua e dialetos, religiões, etnias e raças, gerando sociabilidades e insuspeitadas formas de 
intolerância (étnicas, raciais, de gênero, religiosa, entre outras), discriminação, opressão ou tirania, na mesma escala em que se desenvolvem as diversidades, a liberdade. Nas palavras de lanni:

\begin{abstract}
"Na cidade estão presentes as condições e produtos da dinâmica das relações sociais, do jogo das forças políticas e econômicas, da trama das produções culturais. Ela pode ser simultaneamente mercado, fábrica, centro de poder político, lugar de decisões econômicas, viveiro de idéias cientificas e filosóficas, laboratório de experimentos artísticos. Nela germinam movimentos, tensões e tendências, possibilidades e fabulações, ideologias e utopia. Na cidade global está todo o mundo, os que estão e os que não, visíveis e invisiveis, reais e presumíveis. Vão e vem pelo mundo, localizando-se longa e episodicamente ali. Criam um modo de ser, agir, pensar, sentir e fabular de cunho cosmopolita, descolado da nação, província ou região. Nesse sentido a cidade é real e imaginária, vivida e sonhada, desconhecida e fabulada" (lanni, 1997:68; 90).
\end{abstract}

A imagem de uma cidade caleidoscópio evocada por lanni sugere que questões sociais adquirem características de questões simultaneamente urbanas, na medida em que indivíduos enfrentam o embate de carências estruturais - planejamento urbano, recursos habitacionais, saúde, educação - ao mesmo tempo em que convivem com o narcotráfico, violência, xenofobias, entre outras questões.

No caso de São Paulo, assim como na maioria das grandes metrópoles quer da periferia do capitalismo ou não, um dos fenômenos mais 
reveladores da natureza das tensões que envolvem o convívio dos atores sociais e ambiente urbano é a exclusão social.

De acordo com Bursztyn (1997), a expressão "exclusão" evoca valor simbólico e chama atenção para uma realidade que, embora presente nas sociedades da Antiguidade - cujo modelo econômico incorporava a mão de obra escrava -, surge como efeito colateral do capitalismo global com a idéia de grupos "desnecessários", cuja manutenção física não seria de interesse geral dos dominadores. Soma-se ao exposto a reflexão de Nascimento, para quem tais segmentos, além de desnecessários economicamente, são "incômodos politicamente e perigosos socialmente" (Nascimento, 2000:81).

Nesse sentido, o ato de excluir refere-se a um processo social de não-reconhecimento do outro ou de pura rejeição. Para Paugan (1993), a noção de exclusão social é "relativa", variando segundo épocas e lugares, operando como um "conceito horizonte", o qual produz reflexões e contribui para a estruturação de numerosas pesquisas.

Autores como Castel (1991; 1996) e Martins (1997) divergem quanto à caracterização do fenômeno da exclusão social no mundo contemporâneo. No entanto, inúmeros são os estudos que consideram globalização e exclusão social como dois conceitos que definem duas realidades interligadas. Pode-se salientar, na maioria das publicações, a relação entre situações de exclusão com o crescimento do desemprego e, por conseqüência, com o aumento da desigualdade social. Para Touraine (1991), se a globalização designou as características atuais do processo de desenvolvimento do capitalismo em nível mundial, a exclusão é vista como 
sua conseqüência mais aparente e imediata, gerando não só um modo de produção, mas também um processo civilizatório. Na abordagem do autor, a exclusão é o sinal de deslocamento do conflito social capital versus trabalho que emerge na sociedade pós-industrial. O excluído seria, em primeiro lugar, alguém que está fora ou foi posto fora do mercado de trabalho com poucas chances de retorno.

No caso brasileiro, como aponta Nascimento (1997), ao comentar análises de Jaguaribe ${ }^{1}$, a crise econômica enfrentada pelo país a partir de período posterior a 1980 - quando o Brasil afasta-se do crescimento econômico típico do periodo entre 1930 e 1980 - agravando os problemas sociais, gerou uma estrutura social heterogênea que tende a criar situações crescentes de exclusão social. Assim, parcelas da população brasileira, antes incorporadas nos circuitos econômicos, têm sido constantemente ejetadas do sistema, valendo-se para sobreviver do apoio fornecido por programas de assistência social mantidos pelo governo e entidades filantrópicas, de cunho não governamental e/ou religioso, além da benemerência ocasional da sociedade civil.

Esses homens e mulheres "desnecessários", para quem a infraestrutura privada, como habitação, vai-se tornando inacessível, transformam o espaço público das calçadas em seu universo de vida e sobrevivência. Não se trata somente de tradicionais mendigos, deficientes físicos ou mentais, dos "vagabundos", hippies, iletrados como noutros tempos.

\footnotetext{
${ }^{1} \mathrm{O}$ autor refere-se aos seguintes trabalhos de Jaguaribe: Jaguaribe, H. e col. Brasil, 2000. Para um novo pacto social. Rio de Janeiro: Paz e Terra, 1986; Jaguaribe, H. Brasil, reforma ou caos. Rio de Janeiro: Paz e Terra, 1989.
} 
De acordo com Pochmann (2003), na atualidade, em grandes cidades, é possível localizar uma nova forma de exclusão social estreitamente ligada ao mundo tecnológico e globalizado: se antes a população excluída geralmente tinha baixa ou nenhuma escolaridade, vinha de familias numerosas, era migrante e tinha ocupação mal remunerada, hoje, na nova exclusão, as pessoas não são analfabetas, têm escolaridade, vêm de famílias pequenas; já são cidadãos urbanos, mas estão desempregados. Em outras palavras, sem vencer a antiga forma de exclusão social, agregou-se às ruas da cidade uma nova leva de pessoas, que embora letradas, não têm acesso aos direitos sociais básicos, principalmente ao emprego regular, moradia e segurança ${ }^{2}$.

Podemos considerar, a partir de Escorel, a exclusão social como um processo complexo, caracterizado não só pela extrema privação material, mas, principalmente, porque essa mesma privação material "desqualifica seu portador, no sentido de que lhe retira a qualidade de cidadão, de brasileiro, de sujeito e de ser humano, de portador de desejos, vontades e interesses legítimos que o identificam e diferenciam" (Escorel, 2006:81).

Vista como produto da exclusão social, a população em situação de rua, observada por Vieira e col. na cidade de São Paulo, apresentou como principais características: "extrema mobilidade", ausência de lugar fixo de

\footnotetext{
${ }^{2}$ Dados mais recentes da Pesquisa Nacional sobre População em situação de rua (Unesco - MDS) para algumas capitais brasileiras - dentre as quais não se inclui São Paulo revelam que a maior parte dos moradores de rua alegam como principal razão para viver nas ruas o desemprego, 30\%, e conflitos familiares, 29\%. (O Estado de São Paulo, $29 / 04 / 2008)$
} 
moradia, falta de "convivência permanente com o grupo familiar" e "trabalho irregular" (Vieira e col., 2004:22).

Ainda que obtenham alguma renda, o fazem de forma assistemática - através de "bicos" -; são considerados perigosos pelos não moradores de rua, na medida em que praticam delitos, ou simplesmente, são estigmatizados como risco à segurança pública. O mundo dessa população restringe-se às ruas e seu trabalho se dá nas ruas. Por esta razão, afirmou Bursztyn, "suas atividades produtivas, muitas vezes, resumem-se à obtenção do estritamente necessário à subsistência imediata" ${ }^{3}$ (Bursztyn, 1997: 20).

Vieira também ressaltou que "a falta de convivência com o grupo familiar e a precariedade de outras referências de apoio afetivo e social fazem com que esses indivíduos se encontrem, de certa maneira, impedidos de estabelecer projetos de vida e até de resgatar uma imagem positiva de si mesmos" (Vieira e col., 2004:155).

O morar na rua pode levar o sujeito a dificuldades de identificação com um lugar social de pertencimento, ao mesmo tempo em que procura encontrar, nesse contexto, maneiras específicas para suprir necessidades vitais, emocionais, simbólicas, entre outras.

A experiência do morar na rua implica, portanto, estabelecimento de vínculos com outros indivíduos em situação de rua, instituições assistenciais

\footnotetext{
${ }^{3}$ Segundo dados da já referida Pesquisa Nacional sobre população de rua, de cada 100 pessoas pesquisadas, $72 \%$ afirmaram trabalhar, sendo o maior percentual, $28 \%$, na coleta de materiais recicláveis e os demais como flanelinhas, carregadores, trabalhadores de construção civil e no setor de limpeza. Destes, somente $16 \%$ disseram pedir esmolas para sobreviver (Fonte: O Estado de São Paulo, 29/04/2008).
} 
e programas governamentais, além de contato com a população urbana, composta por transeuntes, moradores e freqüentadores de áreas contíguas às ocupadas pelo morador de rua que the configuram o espaço social de vida no mundo da rua.

Borin atentou para as relações entre moradores de rua e a sociedade civil ao afirmar o caráter paradoxal que estas assumem, variando entre isolamento e sociabilidade. Na opinião da autora, "muitas vezes são considerados perigosos, vagabundos, sujos ou mesmo ignorados (...); em outras vezes são alvos de assistencialismo e caridade, passando pela omissão, pelo descrédito e chegando à repressão" (Borin, 2003:51).

Nesse sentido, a população em situação de rua composta por homens e mulheres poderia ser pensada, a partir da acepção de lanni (1997), como parte daquela parcela de humanos "invisíveis e presumíveis", vivendo na metrópole paulistana.

\subsubsection{Caracterização sócio-demográfica da população de rua}

Em uma primeira aproximação ao problema sob investigação, entendemos como população vivendo em situação de rua, indivíduos que temporariamente ou, permanentemente, pernoitam em espaços públicos, tais como calçadas, praças, jardins, cemitérios, sob viadutos e sob marquises. Além disso, consideramos aqueles grupos ou indivíduos que, sem residência fixa, recebem assistência de albergues e casas de convivência. 
A maioria dessa população persegue regularmente "um leque de estratégias para a sobrevivência, mobilizando-se espacialmente na cidade dentro de um raio de ação delimitado, previamente conhecido e escolhido por cada um, com os quais possui alguma afinidade, em função de atender suas necessidades básicas" (Borin, 2003:45).

Ainda que passíveis de "caracterização operacional", moradores de rua não se constituem em uma população homogênea. Segundo Borin,

"a multiplicidade de características pessoais que este segmento apresenta, dificulta a utilização de uma definição unidimensional. A variedade de soluções dadas à sobrevivência e formas de abrigo, o tempo de permanência na rua, a trajetória anterior à situação de rua, a herança cultural e social (os valores vividos anteriormente), o tempo e as formas de rompimento dos vínculos familiares/comunitários, os tipos de socialização que se consolidam na rua, a rotina espacial, o uso de substâncias químicas- álcool/drogas- e o seu grau de comprometimento, as condições de auto-estima, sexo, idade, escolaridade e as formas de interação que almejam, são fatores que dificultam uma conceituação que não seja reducionista ou mesmo unifocal e nos conduz à idéia de uma tipologia dentro dos moradores de rua na cidade" (Borin, 2003:44).

Quanto à busca de caracterização da diversidade dessa população, autores como Bursztyn (2000) estabeleceu para a população de rua em Brasília, 12 grupos, configurados a partir de situações variadas que envolvem as relações dos indivíduos com o mundo do trabalho informal e com suas histórias de vida, incluindo opções pessoais, visões de mundo, 
formas de sobrevivência e estabelecimento de vínculos sociais circunstanciais ${ }^{4}$.

Na tipologia de Vieira e col. (2004), o grau maior ou menor de inserção na rua determina categorias para essa população. Assim, a partir de situações diferenciadas, há: o ficar na rua - indivíduos que aí estão circunstancialmente, sem recursos para pensão e sem vagas em albergues-, o estar na rua - outros que chegaram à situação de rua recentemente e começam a estabelecer relações com pessoas há mais tempo na rua - e o ser da rua - aqueles para quem a rua transforma-se em espaço de moradia definitiva, ainda que possa haver uso esporádico de outros locais de alojamento.

Giorgetti (2006), em balanço crítico sobre a produção cientifica acerca da temática em questão observou que dos poucos trabalhos publicados, a maioria prima pela vinculação do morador de rua à imagem de trabalhador, no sentido de desconstruir o preconceito que os designa como mendigos e vagabundos.

No que tange aos dados quantitativos sobre a população de rua na cidade de São Paulo, em 1994 a Secretaria Municipal da Família e de Bem Estar Social localizou 4549 indivíduos "sem teto".

O Censo nacional realizado em 2000 pelo IBGE não incluiu pessoas em situação de rua ao apresentar os dados de toda população brasileira com o argumento de que, por se tratar de indivíduos sem domicílio fixo, a

\footnotetext{
${ }^{4}$ Para Bursztyn (2000: 239-246), a população de rua é composta dos seguintes grupos: flanelinhas, catadores - catadores de lixo seco, catadores nômades, catadores complementares-, andarilhos, pivetes, sem lixo e sem teto - mais ou menos sedentários -, sem lixo e sem teto errantes, hippies, pedintes de Natal e albergados.
} 
presumida mobilidade geográfica por pontos inexatos de uma cidade impossibilitaria a contabilização.

A fim de atualizar o tamanho e perfil de tais grupos, no ano 2000 realizou-se o "Primeiro Censo de moradores de rua da cidade de São Paulo" ${ }^{2}$, no qual um contingente de 8706 individuos - compreendendo faixas etárias entre zero e 56 ou mais anos de idade - aparecem em situação de rua na capital paulista, sendo 5013 encontradas em logradouros e 3693 em abrigos e albergues.

De acordo com os dados de 2000 em relação à distribuição por sexo, idade e local de pernoite, homens entre zero e 56 ou mais anos somavam 7278 indivíduos. O grupo feminino contou com 1281 mulheres, cujo recorte etário situou-se entre zero e mais de 56 anos, sendo classificado de acordo com o local de pernoite, albergues ou logradouros. Foram identificadas 372 mulheres assistidas por albergues e 909 que dormem nas ruas. No intervalo entre 18 e 56 ou mais anos, observou-se a maior concentração de mulheres, sendo identificadas 299 mulheres em albergues e 576 nas ruas.

O Censo de 2000 apresenta, além da distribuição espacial e quantificação da população em situação de rua na capital paulista, uma tentativa de definição desta população que considera questões como: escolaridade, tempo de chegada a São Paulo, motivos pelos quais veio morar em São Paulo, ocupação profissional e renda, formas de satisfação

\footnotetext{
${ }^{5}$ Dados da Secretaria Municipal de Assistência Social da cidade de São Paulo em pesquisa realizada pela FIPE - Fundação Instituto de Pesquisas Econômicas.
} 
das necessidades fisiológicas, alimentação, condições de saúde e acesso a serviços afins.

Em 2003, nova pesquisa sobre a população em situação de rua realizada pela FIPE, para a Prefeitura do Município de São Paulo, permitiu observar um aumento do contingente dessa população de 8088 em 2000 foi para 10394 em 2003. Vale notar que tal aumento se deu para albergados que em 2000 eram 3693 pessoas e em 2003 chegavam a 6186 indivíduos, perfazendo, com isso, um crescimento de $67,5 \%$ em três anos para essa população albergada, o que não ocorreu com a população encontrada na rua que de 4395 em 2000, apresentou um valor de 4208 pessoas em 2003.

Buscando uma comparação entre o Censo de 2000 e a pesquisa de 2003, a FIPE ressalta que a necessidade de se subtrair, dos resultados de 2000, as pessoas que pernoitavam nos distritos não incluídos no levantamento de 2003.

Dados mais recentes, segundo a Secretaria de Assistência e Desenvolvimento Social do Municipio de São Paulo, a partir de pesquisa realizada em 2006 pela FIPE, em que foram ouvidos somente moradores de albergue, é possível estimar que há atualmente um universo de aproximadamente 13.000 indivíduos vivendo em situação de rua na cidade de São Paulo ${ }^{6}$.

Nas pesquisas mencionadas, vale observar que a caracterização dessa população embora já contemple a mulher, esta não tem sido foco de estudos específicos em que o reconhecimento da mesma como um grupo

\footnotetext{
${ }^{6}$ Fonte Jornal O Estado de: São Paulo, 30 de abril de 2008:C5.
} 
representativo vivendo na rua, com demandas específicas de gênero, não se apresenta como objeto de preocupação em pesquisas acadêmicas nacionais ${ }^{7}$.

Tal tipo de preocupação se coloca na produção acadêmica mundial, por muitos autores pesquisados, como Novac e col. (1996), que reconhecem a necessidade premente de abordar o tema em profundidade. Nesse sentido, questões investigativas na busca de respostas sobre como estas mulheres se vêem e como são vistas por homens - vivendo na rua ou não e mulheres - que não vivem na rua - apresentam-se de grande relevância para nortear pesquisas na área.

Tendo em vista a complexidade com que se reveste o fenômeno do morar na rua, o desafio que se coloca para a compreensão do mesmo passa, necessariamente, pela busca de articulação de diferentes níveis a partir dos quais o mesmo se manifesta na realidade urbana como na cidade de São Paulo, onde as dimensões micro e macro sociais se entrecruzam desafiando o investigador que dele se ocupa. Em outras palavras, trata-se de contemplar concepções teóricas como a de Elias (1994) que pressupõem como indissociáveis indivíduo e sociedade.

\footnotetext{
${ }^{7}$ Ressaltamos a publicação pioneira no Brasil, a qual se refere às mulheres em situação de rua na cidade de Campinas, São Paulo: TIENE, I. Mulher moradora de rua: entre vivências e politicas sociais. Campinas, Alinea, 2004.
} 


\section{3 A rua, seus sujeitos e seus contornos}

$\mathrm{Na}$ imagem de uma cidade mosaico constituída pela heterogeneidade, conforme pontuou lanni (1997), chama-nos ainda atenção a possibilidade que a mesma oferece de tecer uma diversidade de histórias de vida encontradas no cotidiano urbano, entrelaçá-las na e pela multiplicidade de modos e práticas sociais vividas e compartilhadas por seus habitantes. Nesse contexto, é na cidade que encontramos, na linguagem de Gilberto Velho a convivência de "universos simbólico-culturais dramaticamente distintos", e onde a "interação intensa e permanente entre atores variados, circulando entre mundos e domínios, num espaço social e geograficamente delimitado... [apresenta-se como] um dos traços essenciais [da vida moderna]"(Velho, 1995: 229-230).

Assim, se a grande cidade incorpora, ainda segundo o mesmo autor, "visões de mundo e estilos de vida díspares", igualmente produz processos de diferenciação, desigualdade e exclusão social (Velho, 1995:235).

Nesse sentido, a rua revela-se como espaço material e social em que se observam diversidades, contradições, desigualdades, exclusão e diferentes percepções da realidade de seres humanos sociais concretos quando narram suas experiências de vida igualmente concretas. De acordo com Magnani,

"é a rua que resgata a experiência da diversidade, possibilitando a presença do forasteiro, o encontro entre desconhecidos, a troca entre diferentes, o reconhecimento dos semelhantes, a multiplicidade de 


\begin{abstract}
usos e olhares - tudo num espaço público e regulado por normas também públicas. Este é o espaço que se opõe, em termos de estrutura, àquele outro, o do domínio privado, da casa, das relações consangüíneas" (Magnani,s/d:3).
\end{abstract}

A rua representa para o grupo social composto por indivíduos destituídos de "casa", entendida como espaço privado, o local em que se constrói a céu aberto, na integralidade, o seu cotidiano e sua experiência de vida. Em outras palavras, é o morador de rua que sintetiza nos logradouros da cidade as suas dimensões de vida pública e privada, o que o faz diferente e transgressor da ordem estabelecida, "impondo" aos outros, não moradores de rua, a sua presença e suas especificidades.

Da Matta, em obra clássica, definiu a casa e a rua como referências para a compreensão da gramática da sociedade brasileira, ao afirmar que rua e casa não são simplesmente
"espaços geográficos ou coisas físicas comensuráveis, mas acima de tudo entidades morais, esferas de ação social, províncias éticas dotadas de possibilidade, domínios culturais institucionalizados e, por causa disso, capazes de despertar emoções, reações, leis, orações, músicas e imagens esteticamente emolduradas e inspiradas" (Da Matta, 1987:15).

Podemos, a partir de Da Matta, pensar que o morador de rua desperta no "outro", que transita pela rua, como espaço público, a ambigüidade da vida social que se traduz no reconhecimento de sua diferença. Do confronto de dois domínios culturais distintos, a casa e a rua, 
constrói-se a polaridade que caracteriza o "nós" e os "outros", na medida em que, de acordo com o autor, a rua não seria o local destinado social e culturalmente para a vivência do mundo privado (dormir, fazer suas necessidades fisiológicas, relacionar-se sexualmente, dentre outros).

Escorel, em alusão a Da Matta, considerou que "atividades realizadas fora de seus espaços normais" configuram um processo de "deslocamento" e, por conseguinte, os moradores de rua seriam, nesse sentido, os seres humanos que estão "fora do lugar". Como integram o mundo da rua, seus moradores apresentar-se-iam ainda como "seres liminares que ocupam um espaço singular que Ihes confere as características do próprio espaço [físico]: sujo e perigoso" (Escorel, 2006:235-236).

Para a autora,

"Rua em oposição à casa, esfera privada em oposição à esfera pública. A definição de cada um dos termos da oposição é dada pelos limites estabelecidos com o outro. Há um muro de convenções que delimita as atividades que devem ser exercidas em cada uma destas esferas. $\mathrm{O}$ que o transeunte considera como 'ações privadas realizadas em público', o transgressor pode considerar como 'satisfação das necessidades vitais'... O ato desviante dos moradores de rua está constituído em morar na rua, transgredindo um pilar da organização social que é a separação entre público e privado (Escorel, 2006:238).

De maneira relacional, se na ótica do não morador de rua, aqueles que vivem nas ruas da cidade são os outros, pelo olhar do morador de rua, 
somos nós o Outro Distante, porque não compartilhamos da mesma experiência, muitas vezes nos recusando a reconhecê-la como parte integrante da "nossa" realidade.

A negação, ou "evitação", conforme reflete Pais (2006), torna o fenômeno do morar na rua invisível para grande parte da sociedade que busca, muitas vezes, ignorá-lo como estratégia de defesa.

Simmel (2005:581), ao refletir sobre a vida nas cidades denominou de "caráter blasé", a negação como proteção psíquica, neste caso, manifestada pelo nosso contato com a diferença, o que revela padrões e valores socialmente sancionados como modos de vida de um dado cidadão. No caráter blasé vale lembrar que as idéias de classe, etnia/raça e gênero permeiam tal concepção.Para Almeida, a atitude blasé poderia ser definida como "um movimento reativo da subjetividade que visa à proteção (autoconservação) contra um estado de coisas fundamentalmente desagradável e desprazeiroso. Mais do que isto, a atitude blasé é uma espécie de travestimento da psique com o intuito de proteção e defesa contra a espiral de apelos e demandas de forças externas da sociedade" (Almeida, 1996:43).

O fenômeno de homens e mulheres vivendo em situação de rua caracteriza-se como um fenômeno complexo, imbricado, que envolve sobretudo, uma gama variada de sentimentos, atitudes, valores. Assim, o morar na rua não se caracteriza simplesmente pela existência de vidas de pessoas aparentemente descoladas de uma realidade social ocupando um espaço público. Constitui-se, sim, na presença de homens e mulheres nessa 
condição, que aí passam a escrever suas histórias de vida, estabelecem relações sociais entre si e com os "outros distantes", caracterizados por não serem moradores de rua.

Se Magnani aponta para a rua como um espaço de construção de sociabilidade, no caso do morador de rua a mesma surge como um espaço para o viver integral e adquire o significado de se constituir em uma experiência com múltiplas facetas, ou seja, de gênero, de classe, de sobrevivência, de sociabilidade e de socialização.

Ortega y Gasset, ao considerar a experiência do ser humano no mundo e trabalhar com a idéia de "circunstância" permite-nos refletir sobre o contexto em que se inscrevem os sujeitos de nossa pesquisa. Para o autor, cada ser humano existe, inexoravelmente, em determinado ponto do tempo e do espaço, num preciso ponto geográfico, histórico, social e cultural que denomina de "circunstância". Trata-se de um "contorno", um "envoltório" no qual o ser humano encontra-se circunscrito. Assim, circum-stancia refere-se à presença em torno que representa algo aparentemente externo, de estranho ao homem, mas não irreal. Esteves, em sua introdução ao livro Em torno a Galileu, de Ortega y Gasset, assim exprime o pensamento do autor quanto a esse conceito: "A vida é essencialmente um diálogo com o contorno; é-o em suas funções mais simples, como em suas funções mais sublimes. Viver é conviver, e o outro que conosco convive é o mundo que nos rodeia" (Esteves in Ortega y Gasset , 1989:12).

Afirmou-nos Ortega y Gasset acerca do Homem no mundo: "Eu sou eu e minha circunstância”, ou seja, cada Homem para existir com e na sua 
circunstância forma "um sistema de conviç̧ões sobre o que é seu contorno", de certa forma dialogando com este (Ortega y Gasset, 1989:72).

Dessa maneira, ao considerarmos a importância do "contorno", do contexto, na experiência cotidiana, podemos situar o indivíduo imerso em meio a conexões e redes de relações que lhe configuram como um dado modo de vida e articulam de maneira estreita dimensões micro e macro sociais nas quais diferentes grupos sociais se inscrevem de maneira característica, conforme atesta Martinez e col., que "em boa medida condicionam hábitos, atividades e percepções" sobre si mesmo e sobre o mundo que o cerca (Martinez e col., 1995:288).

Nesse particular, entendemos que abordar indivíduos em situação de rua a partir desse referencial possibilita reter trajetórias de vida diferenciadas não somente de homens, mas também de mulheres em suas singularidades.

Buscar as especificidades da mulher no mundo da rua vai ao encontro de pesquisas internacionais, que desde a década dos anos de 1980 já sinalizam este tipo de preocupação numa aproximação aos estudos de mulheres e de gênero.

Para Watson e Austerberry, em trabalho clássico, publicado na Inglaterra sobre mulheres em situação de rua, na perspectiva de estudos feministas que articulam o patriarcalismo e o capitalismo, tais especificidades podem ser analisadas quando se toma a família e as relações de classe como imbricadas na realidade social dessas mulheres, na medida em que "o status marital e o parentesco afetariam a participação da 
força de trabalho feminina e esta, por sua vez, influenciaria o nível de autonomia e independência das mulheres dentro e fora do casamento" (Watson e Austerberry apud Novac e col., 1996:2) ${ }^{8}$.

Nessa linha de raciocínio, Novac e col. (1996) consideram que "viver na rua é usualmente visto como um problema econômico, mas para as mulheres é um fato estruturado por relações de poder presentes nas relações de gênero ". Dessa maneira, tais relações implicam na criação de um imaginário em relação aos indivíduos em situação de rua em que "mulheres são vistas como dependentes e homens como desviantes [da ordem social estabelecida]" (Novac e col., 1996:2;6).

A dependência feminina, a qual pauta o imaginário social, segundo Passaro (1999), representaria, no caso de mulheres em situação de rua, a exacerbação da ideologia tradicional que envolve a construção social dos gêneros os quais atribuem à mulher o papel de vulnerável e frágil. $E$ isso, seria, segundo a autora, incorporado pelas próprias mulheres.

Nesse sentido, Bourdieu (2003), pontua que o imaginário feminino foi construído, sob formas inconscientes de percepção e apreciação, segundo estruturas históricas de ordem masculina, reproduzidas e atualizadas pela própria sociedade através de suas instituições.

Pesquisas mais recentes sobre mulheres em situação de rua na Inglaterra como, por exemplo, os trabalhos de Jones (1999), Gorton (2000) e Reeve e col. (2006), indicam que somente a partir da década de 90 se

\footnotetext{
${ }^{8}$ A autora refere-se ao trabalho de Watson, S. and Helen A. (1986) - Housing and Homelessness: A Feminist Perspective. London: Routledge Kegan Paul.
} 
consolida a incorporação de relatos de mulheres em situação de rua e suas experiências, nesse contexto, em trabalhos científicos. Essas pesquisas apresentam dados quantitativos e análises qualitativas que procuram ainda conhecer o cotidiano de mulheres vivendo nas ruas e entender o processo que as conduz da casa para a rua, além de sua permanência nessa condição.

Para tais autoras, embora a vida nas ruas seja compartilhada por homens e mulheres, há especificidades na experiência de mulheres em situação de rua, especialmente relacionadas a aspectos microestruturais, tais como violência doméstica, drogadição e sofrimento mental que surgem nos relatos, quando as mesmas apresentam as razões as quais as levaram a viver nas ruas (Jones, 1999; Gorton, 2000 e Reeve e col., 2006).

Além disso, o cotidiano dessas mulheres é revelador de desafios como as relações de gênero, a maternidade, o cuidar dos filhos e a ausência de um lar, o que se configura de maneira particularizada em relação à maioria da população de rua, composta por homens.

A literatura acima representa uma importante contribuição na temática das mulheres vivendo na rua, em um panorama científico no qual há a predominância de publicações relacionadas a cuidados médicos e assistenciais quanto ao controle de epidemias, doenças ginecológicas ou sexualmente transmissíveis e uso de drogas nesse segmento populacional.

Vale salientar, no entanto, que se este enfoque é presente modestamente na literatura mundial, em contexto brasileiro a produção acadêmica, mesmo no que tange às áreas de saúde e de assistência social, 
aparece bastante restrita. Tal fato aponta para a relevância de investigações sobre mulheres em situação de rua que não somente busquem articular as dimensões micro e macro sociais que caracterizam o mundo da rua, mas igualmente reter relações sociais e de gênero presentes nesse universo em que homens e mulheres partilham sua vida cotidiana na metrópole paulistana. Para tanto, uma pequena incursão na literatura especializada permite-nos apontar a importância de se incorporar em estudos sobre mulheres, referenciais de gênero como afirma e reafirma Saffioti $(2004,2005)$ em muitos de seus trabalhos.

Nas ciências humanas e sociais, a incorporação do conceito de gênero como categoria histórica e analítica aparece precisamente após a década dos anos 1960 com a eclosão dos movimentos feministas. Este fato marcou busca de ruptura com o paradigma tradicional, pautado pelo que Reiter nomeia de "male bias", ou seja, a idéia de que a história da humanidade produziu todo seu conhecimento pela ótica da dominação masculina (Reiter, 1975:13).

Tratava-se, em suma, daquilo que se conhece como uma busca de compreensão, por parte das feministas, da dominação masculina sobre a mulher em suas múltiplas manifestações, procurando "incorporar às dimensões subjetiva e simbólica de poder para além das fronteiras materiais e das conformações biológicas" (Araújo, 2000:68-69).

De acordo com Louro, com a incorporação da categoria gênero abriuse um leque de múltiplas possibilidades e abordagens, as quais consideravam, em geral, a "construção social e cultural do feminino e do 
masculino, atentando para as formas pelas quais os sujeitos se constituíam e eram constituídos, em meio a relações de poder". Para a autora, "também as relações de gênero passaram a ser compreendidas e interpretadas de muitas e distintas formas, ajustando-se (a) ou interpelando [diferentes] referenciais [...]" ( Louro, 2002:15).

Para Scott (1995), que elabora um quadro de referência teórica para o estudo de gênero, o termo gênero faz parte das tentativas levadas a cabo pelas feministas contemporâneas para reivindicar certo campo de definição tendo em vista a suposta inadequação das teorias existentes para explicar as desigualdades persistentes entre mulheres e homens. O debate que se trava e que se refere à critica não somente às ciências humanas e sociais, mas também ao empirismo e ao humanismo que desenvolvem os pensadores pós-estruturalistas, leva feministas a encontrarem uma via teórica a qual consideraram e consideram ainda hoje relevante para suas reflexões. É a partir da grande influência que o pensamento pósestruturalista teve e tem para expressivo número de feministas nas quais se pode observar frequentemente a idéia presente, em muitos trabalhos da área, menção à existência de uma teoria feminista e não de teorias feministas, no plural.

$\mathrm{Na}$ visão pós-estruturalista que adota, Scott (1995) assevera a importância de não se buscar uma causalidade geral e universal da realidade social, mas sim uma "explicação significativa", ou seja, um tratamento do sujeito individual, tanto quanto da organização social, procurando articular a natureza das suas interações por considerar que 
ambos têm importância crucial para se compreender, como funciona o gênero e como ocorrem processos de mudança. Em sua perspectiva, fundamental se torna, no processo de interpretação, substituir a noção de que o poder social é unificado, coerente e centralizado por "alguma coisa" que esteja próxima do conceito foucaultiano de poder, entendido como "constelações dispersas de relações desiguais, discursivamente constituídas em campos de força" (Scott, 1995:10) ${ }^{9}$.

Avançando na reflexão, a autora afirma que "o núcleo essencial [de sua] da definição [de gênero] baseia-se na conexão integral de duas proposições", ou seja, "gênero é um elemento constitutivo das relações sociais, baseado em diferenças percebidas entre os sexos, e o gênero é uma forma primeira de significar relações de poder". Com essa colocação, Scott passa a construir aquilo que podemos, numa linguagem epistemológica ou da filosofia da ciência, considerar como características definidoras do conceito de gênero, o fato do mesmo implicar as idéias de que gênero é histórico, é relacional e envolve poder. Tais características são adotadas e incorporadas não somente nos estudos pós-estruturalistas, mas também por outras vertentes teóricas na análise de gênero. Nesse sentido, vale lembrar que, embora a palavra ou termo 'gênero' seja empregado por vários (as) autores(as) são as diferenças de concepções de poder e de relações de gênero, a princípio entre homens e mulheres que definem os

\footnotetext{
${ }^{9} \mathrm{~A}$ autora, nesta citação, refere-se ao trabalho "A história da sexualidade", vol 1. Versão brasileira dessa obra foi publicada em várias edições pela Editora Graal, Rio de Janeiro, com traduções de Maria Thereza da Costa Albuquerque e J. A. Guilhon Albuquerque.
} 
vários conceitos de gênero empregados por pós-estruturalistas e marxistas, por exemplo.

$\mathrm{Na}$ abordagem de Scott (1995), o gênero é composto por diferentes instâncias, devendo estas se apresentarem de maneira articulada, as quais vão perpassando as relações sociais entre sujeitos, ou seja, elementos de ordem simbólica, conceitos normativos, organizações e instituições sociais, política e identidade subjetiva. No processo de interpretação, apresenta-se como questão central para pesquisa histórica - a que a autora se propõe saber quais são as relações entre os quatros aspectos acima referidos, mais especificamente qual "o efeito de gênero" nas relações sociais e institucionais, na medida em que este estrutura a percepção e a organização concreta da vida social. Assim, "na medida em que essas referências [de gênero] estabelecem distribuições de poder (um controle ou acesso diferencial aos recursos materiais e simbólicos), o gênero encontra-se doravante implicado na concepção e na construção do poder em si" (Scott, 1995: 11-12).

O pressuposto básico na proposta de gênero que Scott elabora é o da importância de se contar com uma desconstrução autêntica dos termos da diferença sexual, tendo em vista a necessidade de se rejeitar o que considera caráter fixo e permanente da oposição binária entre homem e mulher ${ }^{10}$ - presente não somente nas ciências humanas e sociais de então,

\footnotetext{
${ }^{10}$ Vale assinalar que Butler enriquece a discussão sobre gênero ao polemizar a dicotomia existente entre a atribuição de gênero na visão binária homem-mulher, uma vez que busca diferenciar sexo, gênero e desejo. Para a autora, se o gênero apresenta significados culturais assumidos pelo corpo sexuado, "não se pode dizer que ele decorra de um sexo desta ou daquela maneira", ou seja, "a hipótese de um sistema binário dos gêneros encerra implicitamente a crença numa relação
} 
mas também nas primeiras teóricas feministas preocupadas em analisar gênero a partir da concepção de patriarcado.

No Brasil, como sinaliza Saffioti (2004), o conceito de gênero alastrou-se rapidamente na década de 1990, difundido rápida e extensamente pelo artigo de Scott, produzido na década dos anos 1980. A despeito das diferentes perspectivas teóricas adotadas por Scott e Saffioti esta reconhece a importância de seu trabalho por "haver ela [Scott] posto em relevo [não somente] o fenômeno do poder [mas igualmente localizá-lo] no centro da organização social de gênero". Considera assim, que suas “análises são válidas e muito importantes para explicar gênero, neste passado mais recente, em cuja duração foi elaborado e implantado o regime do patriarcado". Além disso, Saffioti destaca ser expressivo e valioso o fato de Scott ter afirmado em seu texto que "a atenção ao gênero é frequentemente não-explícita, mas é, no entanto, uma parte crucial da organização da igualdade e da desigualdade " (Saffioti, 2005:47).

Saffioti lamenta, no entanto, que este período esteja "obscurecido por outros argumentos meio ambíguos [da autora] e que ela [Scott] não ressaltou o fato de que o poder pode ser constelado na direção da igualdade e desigualdade entre as "categorias de sexo", termo este empregado pela maioria das autoras francesas, que considera mais adequado para a

mimética entre gênero e sexo, na qual o gênero reflete o sexo ou é por ele restrito". Daí, a asserção de Butler de que a dicotomia heterossexual apresenta-se falsa e vazia de essência tanto quanto a homossexual, isto porque estas representariam tão somente a imitação de um ideal de masculinidade e feminilidade, muitas vezes inatingivel, na medida em que não possuem correspondência alguma com uma suposta essência ou natureza, algo que supostamente estaria inscrito na nossa mente e no nosso corpo. Com isso, a autora contribui para a fundamentação epistemológica e teórica em relação à concepção ontológica de gênero como não naturalizada, mas social e culturalmente construidas (Butler, 2003:24). 
caracterização do fenômeno. Nesta afirmação, a idéia presente em Saffioti é a de que: "como o gênero é visto ora como capaz de colorir toda a gama de relações sociais, ora como um mero aspecto dessas relações, fica difícil dimensionar sua importância, assim como sua capacidade de articular relações de poder. Isto por Saffioti considerar que um dos pontos críticos relevantes na obra de Scott é o fato de a mesma não fazer nenhuma restrição a Foucault aceitando e adotando o conceito de poder, independentemente do âmbito em que este ocorre ou da profundidade e alcance da análise. Pontua a autora que "é sabido que Foucault, embora reúna vários méritos, nunca elaborou um processo de transformação da sociedade, ponto fundamental para uma perspectiva feminista que conteste a dominação masculina" (Saffioti, 2005:47).

Com essa pequena digressão sobre a proposta de Scott é que podemos melhor localizar o pensamento de Saffioti a respeito da concepção de gênero a qual adota e a relação que o mesmo apresenta com os chamados estudos sobre as mulheres.

Para Saffioti, "gênero não é tão somente uma categoria analítica, mas também uma categoria histórica. [...] Sua dimensão adjetiva exige, sim, uma inflexão do pensamento que pode, perfeitamente, se fazer presente também nos estudos sobre mulher. Na verdade, quando aqui [em seu trabalho] se valorizam esses estudos [de mulheres], pensa-se em animá-los com a perspectiva de gênero. A história das mulheres ganha muito com investigações desse tipo" (Saffioti, 2005:45). 
Em relação à aproximação de estudos de mulheres e de gênero, Saffioti reconhece que "sem dúvida deu-se, com este último, um passo importante para as relações homem-mulher, que nem sempre pareciam preocupar (ou ocupar) cientistas". No entanto, em tais estudos, lembra que se "as mulheres eram, como categoria social, discriminadas, o eram por homens na qualidade também de grupo. Mas, como quase tudo que é óbvio passa despercebido, houve vantagens nessa mudança conceitual". Afirma a autora, "gênero diz respeito às representações do masculino e do feminino, a imagens construídas pela sociedade a propósito do masculino e do feminino, estando estas inter-relacionadas, ou seja, ao pensar o masculino evocamos o feminino e vive-versa (Saffioti, 2005:45;116).

Louro assinala, a partir de leitura do trabalho de Barbara Johnson ${ }^{11}$, que essa autora, como outras feministas pós-estruturalistas, assumem não haver nada de natural no gênero em si mesmo, pelo "fato de a diferença de gênero residir na linguagem invés de residir no referente" (Louro,2002:18), aspecto que diferencia do ponto de vista ontológico as perspectivas pósestruturalistas e marxistas na abordagem de gênero.

Afirma ainda Louro que, "embora seja difícil traçar um eixo comum às teorizações propostas pelas feministas pós-estruturalistas, constituindo-se [este em] um pensamento plural. Todas compartilham da "oposição ao discurso patriarcal, com críticas e proposições que definem esses discursos

\footnotetext{
${ }^{11}$ A autora refere-se ao trabalho de Barbara Johnson, intitulado "Feminist, theory and criticism. Postsctruturalist feminisms".
} 
de diferentes modos e seguem linhas argumentativas originais" (Louro, 2002:18).

Saffioti, a partir de uma perspectiva dialética, contrapõe-se, especialmente a essa negação do emprego de gênero articulado ao conceito de patriarcado. Diferentemente de feministas pós-estruturalistas, a autora toma o patriarcado e gênero como categorias históricas numa abordagem que considera gênero como "muito mais vasto que o patriarcado, na medida em que neste as relações são hierarquizadas entre seres socialmente desiguais, enquanto o gênero compreende também as relações igualitárias". Desta forma o patriarcado, cuja base material não foi destruída, a despeito de grandes transformações sociais, econômicas e políticas, ao lado dos avanços feministas apresenta-se como "um caso específico de relações de gênero" no presente momento histórico, compreendendo que a organização social na atualidade, não mudou em essência, mas tão somente na aparência (Saffioti, 2004:118-119; 2005:51).

"o patriarcado não se resume a um sistema de dominação, modelado pela ideologia machista. Mais do que isto, ele é também um sistema de exploração. Enquanto a dominação pode, para efeitos de análise, ser situada essencialmente nos campos político e ideológico, a exploração diz respeito diretamente ao terreno econômico" (Saffioti, 1987:50).

Nessa perspectiva, em que "dominação-exploração constituem um único fenômeno apresentando duas faces", a ideologia machista que fundamenta o sistema patriarcal, socializa o homem para dominar a mulher e esta para se submeter ao seu poder, dominação essa que engendra uma contradição de interesses, ou seja, a preservação do status quo garante os interesses dos homens, ao passo que as transformações no sentido da 
igualdade social entre homens e mulheres respondem às aspirações femininas" (Saffioti, 2004:106-107).

Assim, além de demonstrar em seus trabalhos (Saffioti, 2004;2005) que articular a abordagem de gênero a de patriarcado, longe de representar uma dicotomia, busca preservar o não essencialismo social, promovido pela visão pós-estruturalista, quando dissocia natureza e cultura ao opor sexo e gênero. Saffioti afirma que sua postura "consiste em considerar sexo e gênero uma unidade, uma vez que não existe uma sexualidade independente do contexto social em que é exercida" (Saffioti, 2004:108-109).

Considerando a importância de estudos sobre mulheres em situação de rua, partimos, no presente trabalho, do pressuposto de que ao compartilharem a experiência do viver na rua, numa cidade global como São Paulo, mulheres não somente partilham relações sociais de diferentes naturezas, dentre as quais as de gênero - seja com homens na mesma condição, seja com não moradores de rua com quem essas mulheres dividem o espaço urbano -, mas também que tais relações adquirem especificidades no mundo da rua.

Para tanto, procuramos, em termos analíticos, articular aspectos relativos às dimensões macro e microssocial presentes na caracterização do problema sob investigação, a partir do referencial das ciências sociais, ao lado de uma busca de aproximação à abordagem de gênero defendida por Heleieth Saffioti, que possibilita estabelecer em estudos sobre mulheres, relações entre gênero e patriarcado. 


\section{OBJETIVOS}

- Compreender a experiência de a mulher morar na rua na perspectiva das mesmas

- Desvelar o olhar do Outro Distante - entendido como um grupo diversificado de não moradores de rua composto por transeuntes, policiais e prestadores de serviço em áreas contíguas aos entrevistados.

- Desvelar o olhar do Outro Próximo - homens em situação de rua -, em relação à mulher em situação de rua.

- Identificar questões de gênero emergentes nas diferentes falas em relação a mulheres em situação de rua.

- Cruzar os diferentes olhares sobre a mulher em situação de rua, tendo em vista relações sociais, dentre elas as de gênero, neles presentes. 


\section{PROCEDIMENTO METODOLÓGICO}

\subsection{Natureza da pesquisa}

Dada a natureza do problema de investigação, a presente pesquisa se circunscreve a uma abordagem qualitativa, uma vez que centramos a investigação empírica na dimensão micro social ao darmos voz a mulheres e homens moradores e não moradores de rua, tendo em vista, através da história oral, reter significados, crenças, valores, aspirações, motivações dos sujeitos sociais contemplados.

Entende-se por sujeitos sociais ou atores, elementos que através do "uso vernacular" da cidade (do espaço, dos equipamentos, das instituições) em esferas do trabalho, religiosidade lazer, cultura, estratégias de sobrevivência, são os responsáveis por sua dinâmica cotidiana" (Magnani, 2002:18).

Em pesquisas antropológicas com grupos urbanos, Magnani situa sua abordagem como "de perto e dentro", ou seja, atentou para as possibilidades de pesquisa com tais grupos em que o pesquisador é "capaz de apreender os padrões de comportamento, não de individuos atomizados, mas dos múltiplos, variados e heterogêneos conjuntos de atores sociais, cuja vida cotidiana transcorre na paisagem da cidade e depende de seus equipamentos" (Magnani, 2002:17).

$\mathrm{Na}$ presente pesquisa, as concepções acima mencionadas estão pressupostas no estudo de mulheres em situação de rua, a partir de seus 
discursos e de Outros - homens e mulheres em situação de rua ou não sobre sua condição de vida em constante diálogo com seu contorno.

Entendemos contorno ou contexto como o espaço urbano escolhido como local de moradia - ruas e albergues - em que mulheres em situação de rua estabelecem interações sociais de diferentes naturezas não somente entre si, com homens em situação de rua, mas também com outros indivíduos não moradores de rua da metrópole paulistana.

\subsection{Sujeitos da pesquisa}

Na medida em que consideramos a mulher como sujeito imerso na rede de relações que caracterizam a experiência social, no presente trabalho buscamos compreender sua experiência de vida na rua não só a partir de suas próprias percepções, mas também incorporando as percepções de sujeitos sociais - em situação de rua ou não - que compõe seu contorno. Nas palavras de Elias:

" a consciência de nossa reconhecibilidade como distintos de outras pessoas está ligada indissociavelmente à consciência que temos de sermos reconheciveis por outras pessoas. Somente por conviverem com outras é que pessoas podem perceber-se como indivíduos diferentes dos demais. E essa percepção de si como pessoa distinta das outras é inseparável da consciência de também se ser percebido pelos outros, não apenas como alguém semelhante a eles, mas, em alguns aspectos, como diferente de todos os demais" (Elias, 1994:160161).

Víctora e col. (1990), em pesquisa empírica sobre Aids e pobreza em Porto Alegre, reconheceram a importância dos Outros na construção das representações e concepções acerca da doença, da mesma maneira que, 
em nossa pesquisa, igualmente observamos, como as autoras acima, que os outros se definiam em função de sua proximidade ou distância espacial e ou simbólica. Nas palavras de Víctora e col., o Outro Distante seria "um outro que pertencia a um mundo completamente diferente daquele no qual as pessoas estavam inseridas" e o Outro Próximo, "alguém que se conhece pessoalmente e com quem se compartilha uma série de espaços, de pessoas e valores, enquanto que o outro distante [...] possui uma existência quase imaginária - existência pensada mediante imagens construídas pela mídia ou por histórias contadas - não pressupondo nenhuma relação direta" (Víctora e col., 1990: 94-95).

Dessa maneira, entendendo os Outros como próximos e distantes, entrevistamos não somente mulheres em situação de rua, quanto a sua condição, mas também membros da sociedade civil - o Outro Distante, porque não partilham do mesmo modo de vida - e homens em situação de rua - o Outro Próximo - com os quais mulheres partilham o viver no mundo da rua.

No caso dos homens em situação de rua, o pressuposto básico é o de que, vivendo nas mesmas condições, estes e as mulheres tecem relações sociais - dentre elas as de gênero -, partilham de estratégias de sobrevivência e processos de adaptação, dentre outros aspectos.

Nesse sentido, os olhares desses Outros, distantes e próximos, sobre mulheres em situação de rua apresentam-se, do ponto de vista teórico e empírico, como de suma importância, quando se considera a assertiva de Elias (1994), antes mencionada. 
Com essa estratégia metodológica buscamos ampliar e aprofundar as possibilidades de estudo sobre a mulher e suas relações no mundo da rua, ao visar, no processo de análise, o cruzamento desses vários olhares sobre a mesma.

Para tal, na presente pesquisa foram classificados três grupos diferenciados de homens e mulheres entre 18 e 60 anos:

a) Grupo 1 - Mulheres em situação de rua.

b) Grupo 2 - O "outro" próximo: homens moradores de rua;

c) Grupo 3 - O "outro" distante: homens e mulheres, não moradores de rua, como policiais, prestadores de serviço e transeuntes (em locais contíguos aos espaços de permanência de mulheres em situação de rua);

O grupo 1 (Anexo 1) contou com 20 mulheres divididas em dois subgrupos, a saber: mulheres atendidas em abrigos/albergues e programas assistenciais da cidade e mulheres as quais vivem nas ruas de São Paulo, que não aderem sistematicamente aos programas assistenciais ou ao atendimento em abrigos/albergues.

Quanto ao grupo 2 (Anexo 1), foram selecionados 10 homens em situação de rua. O grupo 3 (Anexo 1) foi composto por 10 transeuntes e prestadores de serviço, sendo 4 policiais (2 homens e 2 mulheres), 4 
transeuntes (2 homens e 2 mulheres) e 2 prestadores de serviço (1 homem e 1 mulher).

A seleção dos entrevistados foi realizada de diferentes maneiras. Em alguns casos, os entrevistadores envolvidos na pesquisa foram instigados a observar as ruas em que cotidianamente transitavam como, por exemplo, no caminho de casa para seus locais de trabalho, identificando mulheres e homens em situação de rua, em seus respectivos trajetos. Em outros casos, parques, praças e determinadas ruas de regiões da cidade lugares reconhecidos por concentrarem parcela da população em situação de rua - foram visitados pelos pesquisadores que, mediante observação do cenário, identificaram os possiveis entrevistados, abordando-os e convidando-os a participarem desta pesquisa. Assim, no caso de um grupo de pessoas vivendo próximo a um hospital - como realmente aconteceu - o porteiro do hospital, ambulantes, transeuntes e pacientes constituíram o entorno, compondo o grupo do Outro Distante.

Desta forma, somente durante o trabalho de campo, foi possivel definir, caso a caso, com base na observação etnográfica a que categoria profissional pertenceriam os sujeitos do grupo 3 , considerados os diferentes cenários onde homens e mulheres em situação de rua seriam entrevistados.

Nos casos de Albergues e Casas de Convivência, tais instituições foram escolhidas mediante listagem fornecida pela prefeitura e por contato prévio já estabelecido na fase inicial da pesquisa, durante o periodo de préteste dos roteiros temáticos. Vale ressaltar que quando os pesquisadores, devidamente identificados, apresentaram-se nas instituições para realizar as 
entrevistas, os funcionários responsáveis pelos mesmos indicaram os prováveis entrevistados, sem que pudéssemos escolhê-los livremente. Tal fato pode, ao que parece, ter interferido na livre expressão dos mesmos em relação aos temas abordados, muito embora tenhamos observado, na maioria dos relatos, a existência de críticas ao albergue como instituição, organização, sem menção, no entanto, a funcionários.

\subsection{Levantamento dos dados}

Conforme observado, as entrevistas foram realizadas a partir de roteiros temáticos específicos para cada grupo de entrevistados, estes caracterizados pela escolha de temas que permitissem colher informações pertinentes aos objetivos da pesquisa, típicas dos depoimentos.

De acordo com Queiroz: "ao colher um depoimento, [diferentemente da história de vida], o colóquio é dirigido diretamente pelo pesquisador, que pode fazê-lo com maior ou menor sutileza, mas na verdade tem nas mãos o fio condutor da pesquisa. Da 'vida' de seu informante privilegiam-se acontecimentos que venham se inserir diretamente no trabalho, e a escolha é unicamente efetuada por este critério" (Queiroz, 1988:21).

A opção por entrevistas com roteiros do tipo temático (Meihy, 1998) incluiu o critério flexibilidade, ou seja, o entrevistado/informante tem a liberdade de narrar acontecimentos e experiências relacionadas com as questões propostas pelo entrevistador no decorrer das entrevistas. Dessa forma, questões e situações específicas relevantes que emergirem no 
momento da entrevista e mereceram aprofundamento no decorrer da mesma, foram incorporadas pelo pesquisador durante o processo.

Entrevistas dessa natureza oferecem, segundo Bourdieu, a possibilidade de:

"uma situação de comunicação completamente excepcional, livre de constrangimentos, principalmente temporais, que pesam sobre a maior parte das trocas cotidianas e abrindo-lhes alternativas que o incitam ou o autorizam a exprimir mal estares, faltas ou necessidades que ele descobre exprimindo-os, o pesquisador contribui para criar as condições de aparecimento de um discurso extraordinário, que poderia nunca ter tido e que, todavia, já estava lá, esperando suas condições de atualização" (Bourdieu, 2007:704).

Em nossa pesquisa, observamos em algumas entrevistas, notadamente no caso de mulheres em situação de rua, manifestações espontâneas de choro e incômodo - muitas vezes verbalizado - por parte dessas mulheres ao relembrarem histórias dolorosas de suas vidas. Em dois casos de entrevistas realizadas em albergue, as mulheres não quiseram falar com seus filhos por perto e, ao chorar, explicavam-se dizendo ser penoso remexer em tudo o que já passaram na rua.

Tais situações discutidas por Bourdieu são desafios ao pesquisador que, muitas vezes sente-se um invasor da privacidade alheia, indagando-se até que ponto pode-se e deve-se perscrutar a vida do outro - embora atendendo aos "imperativos" da pesquisa - ainda que este aceite ser entrevistado? Fariamos nós a mesma coisa que esses homens e mulheres, caso um estranho - sim, éramos estranhos - chegasse amavelmente e nos fizesse perguntas sobre nossa vida intima, nossos sofrimentos, traições, preocupações, medos? 
Findo o colóquio, esse mesmo estranho agradeceria com amabilidade, iria embora e deixaria o entrevistado submerso no mundo de suas emoções recém reveladas.

Estas são algumas das questões que perpassam diferentes dimensões da relação entrevistador e sujeito entrevistado, especialmente porque envolve o aspecto ético no processo investigativo dessa natureza.

Com tal cuidado, para a realização das entrevistas, além da autora desta tese, contamos com três outros entrevistadores - uma socióloga, uma psicóloga e um antropólogo - e com a estrutura de uma empresa, com experiência em pesquisas de campo. Por meio de reuniões sucessivas pudemos discutir o projeto da pesquisa, trocar experiências quanto às formas de abordagem e seleção dos entrevistados, uma vez que, em muitos casos, tratava-se de "escolher" o entrevistado em meio a grupos de indivíduos em situação de rua ou no movimento de transeuntes, nos contornos. A equipe foi sensibilizada para o cuidado na abordagem dos sujeitos a serem entrevistados, assim como na realização das entrevistas, pelo fato de que se tratava de trazer à tona situações de vida, intimidades, lembranças, por vezes, dolorosas.

A opção por entrevistas pela técnica de depoimentos foi ainda definida em virtude da natureza nômade que caracteriza o modo de vida da população em situação de rua. Assim, a mobilidade de homens e mulheres no espaço da cidade, associada ao grande número de sujeitos envolvidos na 
pesquisa, impossibilitaria a realização de estudos longitudinais, típicos das histórias de vida.

As entrevistas foram gravadas e ocorreram após observação prévia, seguida de abordagem em que o entrevistado é convidado a participar da pesquisa, mediante consentimento livre e esclarecido (Anexo 3) assinado pelo mesmo.

Além da utilização de entrevistas, observações ocasionais apreendidas no cotidiano das mulheres em situação de rua, bem como visitas a albergues e abrigos dirigidos à população feminina de rua e/ou masculina em situação de rua, foram devidamente registradas em “anotações de campo" (ver Anexo 2).

\subsection{Tratamento e interpretação das narrativas}

A partir dos relatos orais obtidos, as entrevistas foram, depois de transcritas, revisadas pelos próprios entrevistadores, logo depois a sua realização, a fim de garantir maior fidelidade à transcrição.

$\mathrm{Na}$ interpretação dos dados consideramos o produto das entrevistas como discursos dotados de conteúdos significativos (Lima, 2003; Rocha e Deusdará, 2005), relacionados aos cenários da cidade em que mulheres em situação de rua constroem suas relações sociais, dentre elas as de gênero.

A análise discursiva é vista como um espaço de articulação entre o mundo da linguagem e o mundo social, na medida em que consideramos que o falado expressa a materialidade da experiência vivida em que 
subjetividade e objetividade se encontram num processo no qual o indivíduo, como sujeito social, interioriza a exterioridade e exterioriza a interioridade, para usarmos a terminologia de Pierre Bourdieu, presente em várias de suas obras, na dinâmica dialética que constitui simultaneamente sujeito e sociedade. A idéia presente é a de que as narrativas, antes de revelarem os sujeitos entrevistados como sujeitos individuais, expressam de fato que "sujeitos são agentes que atuam e que sabem, dotados de um senso prático [...] de um sistema adquirido de preferências, de princípios de visão e de divisão [...], de estruturas cognitivas duradouras [...] e de esquemas de ação que orientam a percepção da situação e a percepção adequada" . Trata-se do habitus, "essa espécie de senso prático do que se deve fazer em dada situação" (Bourdieu, 2005:42).

Do ponto de vista operacional, alguns passos gerais podem ser mencionados como partes do processo de leitura e análise dos conteúdos significativos presentes nos relatos orais dos entrevistados.

a. Realizamos uma primeira leitura de todas entrevistas, a partir da qual pudemos identificar algumas palavras-chave (simples ou composta) ou mesmo expressões que pudessem conter conteúdos significativos para a analise do tema, objeto da pesquisa.

b. Num segundo momento, buscamos estabelecer relações entre as unidades de registro, ou seja, palavras-chave ou frases, tendo em vista definir categorias específicas relevantes para a análise dos discursos. Vale observar que, nesse processo, tais categorias relacionavam-se de maneira estreita com os temas constantes nos roteiros temáticos, os quais representavam aspectos de interesse a serem contemplados na pesquisa. 
c. Finalmente, foram construídas categorias gerais a partir da articulação de categorias específicas capazes de apresentar uma linguagem menos empírica, portanto, mais próxima de conceitos teóricos. A partir de então, pudemos eleger as categorias gerais mais significativas, de acordo com os objetivos da pesquisa, que constituíram o denominado corpus do trabalho e permitiram a construção de uma unidade discursiva, do ponto de vista cientifico ${ }^{12}$.

No processo de interpretação das narrativas, para a proteção e respeito daqueles que nos confiaram suas histórias, suas visões de mundo, seu tempo, escolhemos nomes fictícios de personagens oriundos da mitologia greco-romana, como a moradora de albergue Héstia, a policial Erina e o homem em situação de rua Hérakles.

\subsection{Aspectos éticos}

De acordo com as normas estabelecidas pela Resolução 196/96 do Conselho Nacional de Saúde (Ministério da Saúde 1996), os participantes do presente estudo receberam informações sobre o mesmo, sendo que sua participação foi voluntária. Os sujeitos que, mediante explicação dos objetivos da pesquisa, aceitaram atuar como informantes, tiveram garantidos o sigilo das informações declaradas, mediante gravação identificada por

\footnotetext{
${ }^{12}$ Para uma aproximação à estratégia metodológica empregada no processo de construção das categorias e unidades discursivas, veja-se, por exemplo, Minayo (1992: 209-211).
} 
número e nome fictício, bem como a liberdade de desistência sem prejuízo algum ao entrevistado.

Todos os participantes assinaram Termo escrito de Consentimento Livre e Esclarecido (Anexo 3), no qual estão explícitos os objetivos, as garantias e os direitos do entrevistado. 


\section{ANÁLISE DOS DISCURSOS}

"Me perguntas por que compro arroz e flores? Compro arroz para viver e flores para ter algo pelo que viver."

Confúcio

\subsection{Retratos de mulheres em situação de rua}

\section{Ártemis, 42 anos, vivendo na rua}

Numa tarde, sob o viaduto do Minhocão, Ártemis dormia coberta, em um agrupamento de quatro pessoas que se acomodavam junto às grades do referido viaduto. Os pertences de Ártemis se limitavam ao cobertor e uma sacola de supermercado com roupas sujas.

Após o contato inicial, Ártemis aceitou falar conosco e relatou sua infância e a vida na rua.

Durante a entrevista demonstrou-se arredia, atendo-se a responder o que the era perquirida ao mesmo tempo em que brincava com os transeuntes que passavam.

Segundo a mesma, nasceu no norte do país, mas veio para São Paulo ainda bebê. Da infância revelou ter boas recordações, que diante de sua situação atual, vivendo na rua, fariam parte de seu passado. "Agora está tudo mudado", salientou Ártemis.

Declarou a entrevistada que seus pais haviam morrido e que não há contato freqüente com seus dois irmãos. Ártemis relatou que teve uma filha de 13 anos - com quem diz falar freqüentemente pelo telefone - morando com sua cunhada, na zona sul da cidade. Sempre que tem dinheiro, salientou, vai visitá-la. 
Antes de morar na rua, Ártemis narrou que tinha sua casa na Avenida São João, trabalhava em casa de família, mas quando a patroa morreu, perdeu o emprego e não pôde mais pagar o aluguel. Assim, viu-se desprovida de recursos, sem ajuda - não menciona auxilio da família - e acabou indo para a rua. A opção por albergues é descartada pelo medo de desentendimentos entre os usuários dessas instituições: "tem muita briga [nos albergues]", afirma Ártemis.

Quando da realização dessa pesquisa, a entrevistada relatou que para garantir algum dinheiro, atendia carros e também contava com a ajuda das pessoas que passam. Sobre seu cotidiano, Ártemis nos revelou que, embora esteja na rua, toma banho todos os dias, geralmente no terminal de ônibus A. G., ou então na casa de amigas. É na casa dessas amigas, também, que disse lavar as roupas sujas que guarda na sacola de supermercado.

Quando indagada sobre seu maior sonho, a resposta foi ter uma casa e um emprego para ganhar seu dinheiro, pois, segundo ela, "a rua não é lugar para ninguém viver".

Apesar de morar na rua há oito meses, Ártemis disse, ainda, não ter se acostumado com essa vida, e acredita na melhoria de sua situação quando começar a trabalhar. 


\section{Athena, idade não revelada, morando em albergue.}

$\mathrm{Na}$ sala de televisão de um albergue, na região central de São Paulo, muitas mulheres assistiam a programação vespertina e conversavam, com exceção de uma, que permanecia em silêncio, como que alheia ao contato com as outras pessoas ao seu redor. Assim encontramos Athena, mineira, há um mês e meio no albergue, em companhia de marido e do filho de cinco anos.

Athena relatou estar deprimida desde que chegou ao albergue. Com a expressão facial sempre triste, olheiras marcadas, durante a entrevista falou pouco, sempre num tom muito baixo, carregando o filho no colo. Quando foi indagada sobre sua vida na cidade de São Paulo, chorou dizendo não gostar da cidade. Em muitos momentos, permaneceu em silêncio e chorou, sem responder o que lhe era indagado.

Segundo Athena, em sua terra natal morava com os pais e, logo que casou, veio tentar a vida com o marido em São Paulo. Conseguiram um emprego de caseiros, num sítio em Aldeia da Serra - SP, onde trabalharam por três anos. Quando o sítio foi vendido, os patrões prometeram uma indenização em dinheiro, pelo tempo de serviço, mas até o momento de nossa entrevista Athena e o marido não haviam recebido nada.

Assim que deixaram o sítio, prosseguiu Athena em sua narrativa, ela e o marido seguiram até a rodoviária, mas o dinheiro que tinham não foi suficiente para a compra das passagens de retorno a Minas Gerais. Um policial os encaminhou para o albergue, onde estão até hoje. O marido conseguiu um emprego temporário, o filho está matriculado em uma escola 
nas redondezas e, agora, esperam o resultado do processo que abriram contra os ex-patrões, para poderem voltar a Minas Gerais.

No albergue, Athena relata dormir na ala feminina com o filho, e o marido, na ala masculina. Ela elogia os funcionários do local, mas em relação aos outros usuários, reclama que são muito revoltados, e tendem a descontar os problemas nos companheiros de albergue, com comentários maldosos e críticos.

\section{Calíope, 41 anos, moradora de rua}

Em um dia de competições dos Jogos Pan-americanos, a sala de televisão do Núcleo de Serviços e Convivência S. L. G., na região da Avenida Paulista, estava lotada de pessoas em situação de rua que assistiam a programação esportiva. Uma delas era Calíope, que ao ser abordada, relatou utilizar o núcleo com freqüência para tomar banho, fazer refeições e ver TV; aceitou prontamente participar desta pesquisa.

Durante a entrevista, Calíope riu muito, antes e depois de responder a todas as indagações que lhe eram dadas.

Calíope relata que tem boas lembranças da infância: morou com o pai e a mãe até os 21 anos e, nesse período, nunca passaram fome e nem necessidades. Os pais, que de acordo com Calíope, "não se combinavam", atualmente encontram-se separados.

Segundo a entrevistada, ela foi para a rua, há oito anos atrás, porque queria "ser mais dependente dela mesma", e também pela vontade de morar no bairro de Pinheiros. No começo, tentou morar em albergue, mas 
preferiu deixar a vaga que ocupava para pessoas mais necessitadas que ela. Confessa que, no início, chegou a ficar triste, mas hoje considera estar ótima.

Outros motivos que a fizeram deixar o albergue: a sujeira e o excesso de regras. A única coisa que a faria voltar para lá seria se um namorado the pedisse, pois sente que a rua é a sua casa.

A entrevistada relata que tem namorado na rua, mas afirma que "nunca se sabe o dia de amanhã". Com discurso por vezes contraditório, Calíope menciona perspectivas de futuro - um emprego, um salário e um apartamento - e o desejo de, neste mesmo futuro, estar "solteira".

\section{Eurídice, 39 anos, vivendo na rua}

Encontrada na porta da Estação Júlio Prestes, Eurídice aguardava uma vaga para pernoitar em um albergue, depois de ter feito o cadastro junto à equipe do programa "São Paulo Protege". Num ponto de ônibus próximo, encontrava-se uma sacola com os seus pertences.

Natural do estado do Paraná, Eurídice morou "na roça" até os 14 anos, quando saiu de casa. Da convivência com a família, lembra do pai, alcoólatra, que freqüentemente "batia" em sua mãe - Eurídice menciona o "ódio" que sente pelo pai até hoje.

O relacionamento conturbado também com a mãe levou, segundo a entrevistada, ao abandono da família e, aos 22 anos, veio para São Paulo, morar com uma tia. 
Após certo tempo morando na casa da tia em São Matheus, Eurídice conseguiu trabalho numa pensão. Numa noite, depois de um desentendimento com a dona da pensão, acabou indo para a rua. Essa seria a primeira de várias vezes que ficou em situação de rua. De volta à casa da tia, a entrevistada casou-se e teve dois filhos.

O marido, assim como o pai, também era alcoólatra e, em meio a inúmeras brigas, Eurídice abandonou desta vez sua própria casa. Sua mãe levou seus filhos para o Paraná e ela foi morar com uma colega. Conseguiu trabalho como doméstica e trouxe sua filha para morarem juntas, na casa onde trabalhava, até ser despedida. Mãe e filha, não tendo para onde ir, segundo relata a entrevistada, acabaram em situação de rua.

Desses mais de dois anos na rua, Eurídice narrou passagem por alguns albergues. No primeiro, ainda estava com a filha; mas, depois perdeu sua guarda, por estar morando na rua. A menina, que poderia ter ido para adoção, hoje mora com uma tia, irmã de seu ex-marido.

Quando não consegue vaga para dormir em algum albergue, Eurídice se junta a um grupo de mais seis amigas, para se sentir mais segura. Ela já foi estuprada por cinco homens, o que causou um grande trauma, agora superado com tratamento psicológico.

O maior tempo que passou dormindo na rua, sem albergue, foi um mês, de onde relata frio e solidão.

Dos albergues, a entrevistada relata brigas e "muita gente diferente misturada". 
A entrevista foi marcada pela dor de Eurídice ao narrar a perda da guarda da filha.

Durante a entrevista, Eurídice se emocionou quando contou da perda da filha, mas demonstrou controle quando ao relatar o estupro.

Apesar das dificuldades que encontra vivendo em situação de rua, a entrevistada alimenta o sonho de reaver a menina para, juntas, retornarem ao Paraná, pois, segundo ela, não existe futuro para quem está nas ruas.

\section{Dóris, 20 anos, vivendo em albergue}

Encontrada dormindo durante o dia em um sofá no albergue, Dóris tinha consigo o filho de um mês e meio na ala feminina. Trazia um arranhão no rosto, proveniente de uma briga com outra colega.

Quando abordada, recusou-se a participar desta pesquisa, dizendo sentir dores, com medo de estar grávida e em processo abortivo. Não queria que os funcionários do albergue soubessem da suposta gravidez e recusava-se a buscar ajuda médica.

Após crise de choro inicial, ela mesma se ofereceu para ser entrevistada.

Iniciou seu relato informando-nos que há seis ou sete meses está em situação de rua e, depois de permanecer dormindo na porta de entrada do albergue, foi recolhida.

Da infância, relembra os maus tratos que sofria de sua mãe, como ser chamada de "negra", ouvir que foi encontrada em uma fossa e ser acusada de consumir drogas. Em meio à revolta, pensou em se jogar 
embaixo de um trem que leva passageiros de São Paulo a Santos, mas acabou por entrar no mesmo. Em Santos, morou em uma casa abandonada por meses. De volta a São Paulo, novos conflitos com a mãe e Dóris foi morar com o pai. Lá, conheceu o pai de sua filha, engravidou e o companheiro sugeriu que ela fizesse um aborto. Retornou então à rua e, a partir daí, rememorou todo o sofrimento e sua luta para não perder o bebê.

O relato de Dóris foi entremeado por episódios e narrativas de sentimentos associados a sua vida na rua: o medo de viver constantemente ameaçada pela violência, a insônia, o atropelamento, a tentativa de estupro e problemas de saúde (ela e a filha têm asma).

Dóris chorou várias vezes quando rememorava fatos tristes.

\section{Éris, 50 anos, vivendo na rua}

$\mathrm{Na}$ rua há 15 anos, com passagem por dois albergues, Éris é nascida em São Paulo-SP. Separada, mãe de três filhos adultos e com cinco netos, relatou que fez o papel de "pai e mãe" para educar seus filhos, pois não recebia respaldo do marido. O casamento se sustentou até que um dos filhos foi preso por latrocínio. A partir desse episódio, ela e o marido começaram a beber e, então, separaram-se.

Ela tem o que considera "um bom relacionamento" com os demais filhos, visto que os visita periodicamente, mas prefere viver na rua, onde se sustenta com o que ganha, pedindo dinheiro em faróis da cidade. 
Relatou seu cotidiano na rua, em que para tomar banho vai até a Santa Casa, utilizando o banheiro sem que os funcionários percebam. A roupa é lavada e estendida na rua.

Éris salientou que optou por viver assim, ao invés de nos albergues, devido aos horários pré-estabelecidos das instituições, que a obrigavam a ir para a rua às seis da manhã: "Não é bom ficar na rua, mas é melhor do que ficar no albergue. No albergue tem hora e na rua não tem horário para nada".

No decorrer da entrevista, confidenciou, sem entrar em detalhes, passagem pelo sistema prisional, condenada por crime de estelionato.

\section{Eunice, 36 anos, vivendo em albergues}

$\mathrm{Na}$ sala dos fundos do albergue L. T., Eunice nos concedeu entrevista, relatando passagens anteriores por outros dois albergues, durante os oito anos que está nas ruas.

Morou com a família de criação até os 27 anos, quando, após um desentendimento com a mãe, saiu de casa. Como era adotada, sentia que os pais a tratavam de maneira desigual, preferindo os filhos naturais. A única pessoa na casa que a tratava normalmente era um tio, que faleceu pouco antes de sua ida para a rua. Fazendo um balanço de sua vida, Eunice diz que prefere o jeito de como vive hoje, no albergue, a do que quando vivia com a família.

Teve um companheiro por 12 anos. Durante o tempo em que ficaram juntos, ela engravidou duas vezes, mas perdeu os dois bebês. A primeira 
filha, segundo ela, morreu por culpa das discussões que seu companheiro provocava e, o segundo filho, após apanhar do companheiro, que the deu um chute na barriga. Após mais uma das inúmeras brigas, motivadas, segundo Eunice, pelos excessos do companheiro, alcoólatra, ela decidiu romper definitivamente o relacionamento. Atualmente, o ex-companheiro the paga mensalmente uma pensão de $\mathrm{R} \$ 70,00$.

Para completar a renda, Eunice costuma arrumar trabalhos temporários, entregando panfletos em semáforos. A dificuldade em conseguir um emprego estável, segundo relata, deve-se ao fato de viver em um albergue, pois, quando os empregadores checam seu endereço e descobrem tratar-se de uma instituição para pessoas em situação de rua, não a contratam.

Quando indagada sobre seus sonhos, Eunice sorri e responde: "um emprego fixo, para que possa trabalhar e conseguir uma casa".

Durante a entrevista, Eunice não chorou ao narrar suas experiências, demonstrando distanciamento.

\section{Selene, 55 anos, vivendo em albergue}

Selene, uma senhora de 55 anos, há 11 anos em situação de rua, bem humorada, aceitou prontamente participar desta pesquisa.

Sobre sua infância, passada na cidade de Avaré-SP, mostrou-se nostálgica ao relembrar do passado, dizendo saber que "fez coisas erradas", das quais hoje se arrepende. 
Filha única, relata que apanhava muito da mãe, por ter sido "muito arteira". Na adolescência, foi expulsa de casa pelo pai, após este descobrir que perdera a virgindade e, portanto, tinha "manchado o nome da família". O pai reconsiderou a expulsão mais tarde, porém obrigou-a a casar-se com o namorado.

Vivendo com o então marido, os dois começaram a usar drogas. Primeiro maconha, depois cocaína e assim viveram até a morte do companheiro.

Quando recebeu a notícia da morte do marido, no ano de 1997, Selene narrou ter entrado em estado de choque e ficou dezenove dias hospitalizada em Bauru, onde moravam. Após a alta, descobriu que sua casa, localizada numa favela da cidade, havia sido invadida por "bandidos"; estes, segundo Selene, sequer a deixaram pegar seus documentos. Sem mencionar ajuda da família, Selene foi viver na rua, usando drogas por mais quatro anos.

A partir de 1997, Selene decidiu viajar por todo o Brasil, primeiro vendendo bebidas na rua e, depois, vendendo artesanato, o que aprendeu a fazer em um curso profissionalizante da Prefeitura de São Paulo.

A entrevistada relata que saiu para viver nas ruas, com a roupa do corpo e com um par de chinelos que eram do marido, grandes demais para seus pés.

De carona em carona, seguiu pedindo ajuda e passagens, até chegar em São Paulo-SP. Daí, foi a Salvador, onde conseguiu um emprego como cuidadora de uma senhora de idade. Depois que esta senhora morreu, 
Selene viveu em albergues, vendeu água, refrigerante e cerveja nas ruas de Salvador. De lá, conseguindo passagens com assistentes sociais, começou a viajar de cidade em cidade, dormindo em praças e marquises, e chegou até o Pará, onde relata ter vivido um tempo numa aldeia indígena. Cansada da monotonia da vida dos índios, segundo nos informa, decidiu viajar novamente, retornando a São Paulo em 2003. Na capital paulista, ela nunca dormiu na rua, sempre em albergues. Segundo ela, não dorme nas ruas com medo de que "algum parente a encontre".

Atualmente trabalhando como faxineira numa clínica, Selene não quer mais ficar na rua, pois tem problemas de saúde - já entrou em coma duas vezes: devido ao diabetes e por problemas cardíacos. Mas, diz que, se nada diferente acontecer, pega o dinheiro do trabalho e compra bijuterias para vender em alguma cidade turística, como sempre fez com seus artesanatos.

Selene tem sonhos: uma casa, que também seria seu atelier, moradia e trabalho: "Eu gostaria de ter a minha casa, só que eu não tenho uma casa. Onde eu vou arrumar dinheiro para alugar uma casa?"

Durante a entrevista, Selene relatou com vivacidade suas muitas experiências com drogas, viagens e a perda, para ela irreparável, do companheiro que parece ter transformado sua vida.

\section{Koré, 31 anos, vivendo na rua}

Em um dia de frio intenso na cidade de São Paulo, Koré encontravase sentada nos degraus de uma agência bancária, na Avenida Ipiranga, 
pedindo dinheiro aos transeuntes, com o filho de 11 meses no colo. O bebê era protegido do frio por gorro, luvas e cobertor, que envolvia ambos.

A criança de colo é seu quarto filho, porém o primeiro com o atual companheiro. Os outros três filhos moram em uma casa em Guarulhos com o ex-marido, que a proibiu de vê-los.

Aos cinco anos de idade Koré fugiu de casa. Desde essa época, vive entre a rua, albergues e casas invadidas, tendo, inclusive, passagem pela FEBEM. Atualmente, mora com o companheiro e mais 11 famílias em um casarão invadido, na Rua da Consolação.

Koré relata que, quando precisa de dinheiro para comprar alguma coisa para o filho, vai para a mesma escada e pede esmolas. Seu companheiro trabalha guardando carros, o que também rende algum dinheiro. À noite, os dois se encontram no casarão.

Depois de tanto tempo nas ruas, Koré sabe que "isso não é vida para ninguém", mas também diz que ninguém passa fome, pois sempre foi ajudada pelas pessoas com lanches e dinheiro.

Durante a entrevista Koré falou pouco, atendo-se a responder o que Ihe era perguntado, sem revelar detalhes sobre os assuntos propostos. Sua atenção voltava-se ao filho que carregava no colo e, eventualmente, davaIhe de mamar e também o distraía sempre que ele choramingava ou ameaçava chorar. 


\section{Afrodite, 24 anos, vivendo em albergue}

Com um sorriso cativante, vestida com roupas justas e coloridas, Afrodite, uma potiguar que está em São Paulo-SP há três meses, recebeunos em uma sala reservada, nos fundos do albergue L. T. À vontade durante toda a entrevista, Afrodite aparentava segurança enquanto narrava sua história de vida, inclusive os episódios mais difíceis, num discurso articulado e reflexivo. Chamou nossa atenção seu senso crítico sobre a população em situação de rua, da qual atualmente faz parte.

Sobre sua infância, relatou ser filha adotiva e ter morado com os pais e uma irmã - esta filha legítima, como salienta - até os 16 anos, quando saiu de casa para trabalhar. Do convívio com sua família, percebia que era tratada de maneira diferente em relação à irmã, e este parece ser o ponto central de seus conflitos. Segundo a entrevistada, desde a alimentação, vestuário e escola, sua irmã "ficava sempre com o melhor". Relata-nos ainda chamar seus pais de pai e mãe pelo costume, pois não os considera como tal.

Aos 16 anos conseguiu emprego e foi morar sozinha. Estudou inglês, patologia clínica - trabalhou em um laboratório de análises - e começou faculdade de psicologia. Nesta época, segundo relata, começou a usar cocaína e, quando se deu conta, já estava totalmente dependente da droga, tendo chegado a se prostituir para conseguir comprá-la.

Sentiu-se desesperada pela situação em que se encontrava e decidiu sair de Natal. Seguiu para Salvador, onde ficou devendo a traficantes e teve que fugir para São Paulo. Na capital, ficou alguns dias na casa de 
parentes, mas, por fim, com medo de que soubessem de sua dependência química, foi para a rua.

Durante as duas semanas que ficou na rua, Afrodite costumava dormir em hospitais, na cidade de Osasco. Lá, soube que existiam albergues e saiu em busca de uma vaga.

Para Afrodite, as condições dos albergues que conheceu desde então são satisfatórias. No entanto, critica "o modelo de inclusão social" adotado atualmente, que, segundo ela, é ultrapassado e faz com que os moradores do albergue acabem se acomodando ali. Diz ela: "precisamos de programas eficientes, como reincluir na escola, ter um curso de computação. (...) Então ter um curso técnico e específico para que a pessoa realmente consiga sair do albergue e ter um emprego, que ela realmente consiga se manter sozinha. Só a alimentação, só a acomodação não é o suficiente".

Em processo de reabilitação, Afrodite relata ter "distúrbios emocionais", devido às crises de abstinência. No entanto, conseguiu um emprego de meio período em telemarketing e espera encontrar um segundo trabalho, para então pagar suas dívidas e voltar a ter uma vida digna, "melhor do que a que levava antes das drogas".

\section{Hécate 42 anos, vivendo na rua}

Próximo a um carrinho de cachorro-quente, na zona central da cidade, Hécate tomava café e chamava atenção pela fala agitada e pela voz alta em que criticava os albergues e serviços oferecidos pela prefeitura à população em situação de rua. 
Ao ser abordada para participar desta pesquisa, disse estar em "tratamento psicológico" - relatou uso de medicamentos "controlados" - e não quis falar sobre sua infância. O depoimento de Hécate foi entremeado por devaneios, em que citava o atual presidente do Brasil, a Rede Globo, policiais, juizes, entre outros.

Em outros momentos, pareceu lúcida e relatou ter nascido em Araraquara-SP, tendo ido para a rua há quatro anos porque, segundo ela, perdeu sua casa devido "à corrupção [existente no governo]".

Hécate diz ter passagem por albergues em vários estados, mas prefere viver na rua, embora esta seja "o degrau mais baixo que o ser humano pode ocupar, a queda total". Reclama dos funcionários e das regras que são impostas para ficar nos albergues e conta de um dia em que foi expulsa debaixo de chuva deles no interior do estado. Esse episódio parece ter sido definitivo para que a entrevistada optasse pela vida nas calçadas da cidade de São Paulo.

Ainda assim, sonha com uma casa colorida, com flores nas paredes, bem alegre: "se a parede é branca dá a impressão que a casa está doente. O branco é bom só para hospital."

\section{Hebe, 30 anos, moradora de albergue}

Com o filho de um ano e dois meses no colo, Hebe sente-se à vontade no albergue onde está há dois meses. Segundo ela, é até melhor do que quando morava em uma casa, alugada, onde só cabiam a cama, o 
fogão e a geladeira. Como relata, "a estante ficava do lado de fora, pois não havia espaço no minúsculo quarto" onde moravam Hebe, o marido e o bebê.

Da infância, relembra a vida feliz com os pais e os seis irmãos, na região central de São Paulo. Estudou só até a primeira série, pois “sempre quis mais trabalhar do que estudar". Trabalhou entregando panfletos no farol, guardando carros, como empregada doméstica e também como babá.

Quando conheceu o marido, namoraram por algum tempo e depois foram morar juntos, antes dela engravidar. Quando não tiveram mais condições de pagar o aluguel, tiveram que deixar o imóvel. De lá, seguiram para a casa de um primo do marido, onde ficaram algum tempo. Novamente foram pressionados a sair e acabaram indo para o albergue, onde foram abrigados Hebe, marido e filho. O local é exclusivo para mulheres, mas os assistentes sociais abriram uma exceção, para que o marido pudesse ficar com a criança. Ele trabalha fora, e o filho passa o dia numa creche ali nas redondezas.

Também trabalhando numa frente de trabalho, Hebe pretende juntar algum dinheiro e, dentro de um mês, pretende morar em uma casa.

Numa casa, Hebe acha que seria mais feliz. Os horários préestabelecidos do albergue a incomodam. Sonha com a casa, onde poderá assistir aos programas de TV que gosta, e também seu marido poderá cozinhar as comidas que gostam, na hora que quiserem. 


\section{Hera, 43 anos, vivendo em albergue}

Todos os dias, no final da tarde, quando sai da Frente de Trabalho em que está empregada, na Arquidiocese de São Paulo, capital, Hera volta ao albergue onde está morando para garantir a vaga de mais uma noite. Ela está ali há oito meses, mas não tem vaga fixa. É obrigada a sair às sete e meia da manhã e só pode voltar à tarde para se cadastrar novamente e conseguir dormir ali mais uma noite.

Nascida no bairro do Bom Retiro, Hera teve uma infância tranqüila: estudava, nunca passou necessidades em casa, a família era unida. Relembra das viagens que faziam juntos para o litoral e para Aparecida do Norte, e dos jogos do Corinthians a que foi levada para ver, no estádio. Da adolescência, relata que começou a trabalhar e continuou a estudar, à noite.

Os parentes foram morrendo e, quando tinha 25 anos, ficou sozinha. Trabalhava na indústria têxtil como ploteira, que segundo ela é "um costureiro chefe que faz as peças, corrige todos os defeitos, depois ensina os demais funcionários e coordena toda a produção". Com o salário, conseguia pagar o aluguel e vivia sozinha. Freqüentava o clube nos finais de semana, conversava com os vizinhos, viajava para a praia, tinha uma vida normal. Como a empresa em que trabalhava fechou, não conseguiu mais pagar o aluguel e acabou na rua.

Desde a primeira noite, dormiu numa moradia provisória, na qual ficou um ano, antes de vir para o albergue. Hera prefere a moradia provisória, pois de acordo com ela, é uma casa boa, onde ela podia ficar o dia todo, fazendo suas coisas, limpando a casa ou descansando. Já no 
albergue, ela tem que sair de manhã, e só pode voltar à tarde. Nos finais de semana, quando não trabalha, ela fica sentada num ponto de ônibus lendo jornal, esperando o tempo passar para poder voltar ao albergue.

Esperançosa, pretende voltar a trabalhar para, então, ter uma casa novamente. Gosta do albergue, principalmente dos assistentes sociais, mas não se sente como se estivesse em casa. Durante a entrevista, Hera respondeu rapidamente todas as perguntas, pois não queria que demorasse muito. Ela deixa a sensação de que se considera um pouco diferente das demais mulheres do abrigo, por seguir trabalhando e também por nunca ter morado na rua.

\section{Héstia, 37 anos, vivendo em albergue}

Héstia, grávida de seis meses, recebeu-nos com a filha pequena, ainda nas fraldas, no albergue em que está vivendo atualmente com o marido e o bebê, segundo filho de ambos - o filho mais velho, de quatro anos, mora com uma tia .

Natural do Estado de Minas Gerais, Héstia veio para São Paulo aos onze anos. Da infância em Minas, relembra do pai, alcoólatra, e da mãe, que sustentava a casa. As "coisas" mudaram, segundo relata, quando a família veio para São Paulo. O pai parou de beber, Héstia e as três irmãs começaram a trabalhar para ajudar no orçamento da família. Ela trabalhava de dia e estudava de noite, mas deixou a escola na quinta série.

Esta é a segunda vez que está na rua. Na primeira vez, em 2004, dormiu um dia ao relento e depois foi para um albergue, onde conheceu o 
marido. Começaram a namorar e se mudaram para o interior do estado. No entanto, a vida não prosperou como esperavam e o casal decidiu voltar para São Paulo, onde moravam numa casa alugada.

Com o marido desempregado, sem conseguir pagar o aluguel, tiveram que deixar o imóvel. Como não tinham para onde ir, ou mesmo um local para guardar seus pertences, restou-lhes viver nas ruas. Tudo o que tinham ficou com a proprietária do antigo imóvel.

O filho mais velho ficou aos cuidados da irmã de Héstia, que pretendia tomar conta também da caçula, contra a vontade de seu marido, como ressalta.

Antes de chegar ao albergue, passaram quatro meses na rua, dos quais Héstia relembra com amargura por não ter como tomar banho, lavar roupa e até mesmo de não ter comida. Às vezes, os transeuntes ajudavam, como no dia em que Héstia se sentiu mais feliz na vida: ganhou uma lata de leite, um pacote de fralda, dois cobertores e dez reais de uma senhora que passava.

No albergue, reclama da sujeira que os "12 horas" (pessoas que não têm vaga fixa, só pernoitam no local) deixam, e também de não poder ajudar na limpeza e em pequenos trabalhos na casa. Sempre foi bem tratada por todos os funcionários, e conta que o problema são os próprios moradores, a quem, segundo ela, falta humildade e respeito.

Pretende fazer um curso de manicure ou de crochê, mas, por enquanto, o albergue só oferece cursos de cabeleireiro, padeiro e de costura, coisas que não a interessam. 
Espera o filho nascer para tentar trabalhar e, assim, ajudar o marido a conseguir uma casa para morarem. Num futuro próximo, acha que estará bem melhor do que está hoje, mas salienta que, hoje, vivendo no albergue, já está melhor que há dois meses, quando ainda vivia na rua: "pelo menos aqui eu tenho o meu canto, tenho um chuveiro quente, tenho onde lavar a minha roupa".

\section{Deméter, 23 anos, vivendo em albergue}

Encontramos Deméter em uma sala reservada para nossa entrevista em um albergue feminino na zona oeste da cidade de São Paulo. Esta concedeu-nos uma longa entrevista e, apesar de jovem, impressionou pelas experiências que narrou de sua vida nas ruas.

Deméter nasceu em Guarulhos (SP). Fugiu de casa pela primeira vez quando tinha 14 anos, segundo a mesma, por ter um padrasto alcoólatra que a maltratava muito e por causa da mãe, com quem tinha "muitas brigas". Cansada da vida que levava, preferiu sair de casa.

No começo, buscou hospegadem na casa de parentes, mas sua mãe sempre a descobria e a trazia de volta. Deméter decidiu que não queria ser mais encontrada pela mãe e foi viver na rua. Lá, ainda adolescente, envolveu-se com drogas, passou por vários abrigos e pela FEBEM. Sua mãe a encontrou mesmo assim e a convenceu a voltar para casa.

De volta à casa materna, os conflitos com o padrasto e a própria mãe continuaram e, aos 17 anos, voltou para as ruas. 
Nesta época, conheceu seu ex-companheiro e foram morar juntos em uma casa invadida, na Vila Mariana. Ambos eram usuários de drogas quando Deméter engravidou e decidiu libertar-se da dependência.

O irmão de seu companheiro foi morar na mesma invasão que eles e, como era traficante, a casa começou a ser freqüentada por outros usuários. Após inúmeras brigas com o então companheiro, ela decidiu sair da casa invadida e ter sua filha longe daquele ambiente, e também das drogas. A partir daí, não quis ter mais contato com o pai de sua filha.

Quando deu a luz, voltou para a casa da mãe e lá ficou por seis anos. Mais uma vez, o padrasto a perturbava e Deméter saiu de casa levando a filha. Procurou o albergue, onde foram recebidas "de braços abertos" pelos funcionários e assistentes sociais.

Espera conseguir um emprego para, um dia, realizar o sonho de cursar faculdade de medicina. Tempos atrás conseguiu um emprego, em que ganharia $R \$ 450,00$; mas, não pode ir, porque não tinha com quem deixar a filha [o albergue não permite que crianças permaneçam sem o responsável, o que impede, muitas vezes as mulheres de trabalharem].

Seu objetivo inicial é conseguir um lar para a filha, com uma vida digna. Dos tempos de rua, lembra-se da bagunça e das drogas, mas hoje diz que seu único vício é o cigarro.

Liberdade, segundo ela, é a palavra que define seu passado. O presente é a harmonia, e o futuro, prosperidade. Prefere o presente, onde se esconde dos problemas atrás da risada, não mais atrás das drogas, como fez por muito tempo. 


\section{Diana, 38 anos, vivendo em albergue}

Quando um rato apareceu no albergue feminino L. T., zona oeste de São Paulo, as usuárias do equipamento agitaram-se. Diana, há pelo menos dois anos no L. T., não se abalou e afirmou ser melhor conviver com a possibilidade de um rato despencar na sua cabeça do que viver no albergue misto em que morou anteriormente. "Lá tinha muito homem, muita mulher, muita confusão, muita bebedeira...”.

No L. T. há apenas dois homens: o marido e o filho de uma moradora. O fato de morar apenas com mulheres faz com que, segundo Diana, o ambiente seja mais tranqüilo.

A aparente calma de Diana contrasta com a narrativa que faz de sua vida, conturbada, marcada por violência, sofrimento mental e experiências dolorosas na rua.

Sentindo-se rejeitada pela própria família, que a internava quando "tinha ataques de esquizofrenia", fugiu de casa há quatro anos. Viveu na rua por um mês, até ser achada por um ex-namorado, que a internou. Nesse período, durante o dia tomava banho, lavava roupa e se alimentava em uma Casa de Convivência, na região central da cidade de São Paulo. À noite, dormia na rua.

Certa noite, enquanto dormia embaixo de um viaduto, foi estuprada por três homens: "Até um menino de 11 anos roubou o meu Fundo de Garantia. O menino de 11 anos roubou o meu Fundo de Garantia e ainda me estuprou". 
Diana sente-se segura no albergue: "Aqui é bom porque você pode fumar na hora que quiser. Se eu acordo de madrugada eu posso fumar. Entendeu? Ah, e também tem almoço".

A entrevistada vai regularmente ao Hospital do Capes, onde é acompanhada por médicos. Vai e volta a pé, apesar de ter a carteirinha de acompanhante, o que a isenta da tarifa do transporte público. "Eu ia todo dia. Eu estou com o coração inchado e falei para o médico que ir para o albergue estava me cansando muito, então só ia de segunda e sexta. Agora vou marcar de novo", explica.

Por causa dos seus "surtos", Diana não fez amigos enquanto morou na rua, pois "não queria conversar com ninguém".

Ressalta que faz sempre todos os exames necessários, desde que saiu da rua e não possui nenhuma doença sexualmente transmissivel, o que ela considera uma "graça de Deus".

Apesar dos problemas familiares, Diana mantém contato com a família - mãe, dois irmãos e uma irmã. Sua filha de 10 anos, que mora com uma tia, visitou-a no último dia das mães.

Diana não cogita a possibilidade de voltar a morar com a família: "Agora, fora de casa me dou bem com eles, porque eles vêm aqui, mas conviver com eles não dá".

Seu sonho é se mudar daqui a um ano, um ano e meio para uma pensão: "O problema é que eu não posso morar sozinha. Eu não posso ficar sozinha em casa por causa dos vultos que eu vejo. Eu tenho muito medo", conclui. 


\section{Perséfone, 50 anos, vivendo na rua}

Nascida na roça, no interior de Minas, sem freqüentar a escola, Perséfone, com idade aproximada em torno de 50 anos, foi encontrada sentada em um banco do Parque Trianon, Avenida Paulista, portando três sacolas, uma delas contendo latinhas de aluminio.

Relatou ser a segunda vez que está vivendo na rua, em ambos os casos porque perdeu o emprego. Dorme sozinha, na calçada de uma lanchonete próxima ao Parque, sem contato com outros grupos de pessoas em situação de rua.

Perséfone aceitou falar conosco e relatou seu cotidiano: acorda por volta de 4:30 da manhã, lava o rosto e escova os dentes na rua e de lá segue para Santa Cecília, onde ganha o café da manhã de um conhecido que trabalha em uma lanchonete. No trajeto começa a catar latinhas. Passa parte do dia no Parque (onde é reconhecida por transeuntes e guardas do local), almoça na "Casa de Convivência" que fica nas cercanias e, após as 16 horas, sai novamente pelo bairro a catar latinhas.

Da primeira vez que esteve na rua (em 2003) procurou um albergue, mas desta vez recusou-se por não gostar de "bagunça e sujeira". Ainda tem mãe e irmãos vivos em Minas, mas só os visita quando está "numa boa", ou seja, quando tem condições de levar presentes.

\section{Ariadne, 25 anos, vivendo em albergue}

Ariadne, 25 anos, recebeu-nos na mesa da sala de refeições do albergue L. T., zona oeste de São Paulo, para a entrevista. 
Da infância e adolescência relata as dificuldades de relacionamento com o padrasto - alcoólatra - e com um irmão: "Ele [o padrasto] agredia minha mãe, agredia nós...Colocava a gente na rua até em época de chuva e com isso eu fui me cansando..."

Aos oito anos, indo para a rua e recém chegada à "Cracolândia", começou a cheirar cola e fumar maconha, mas, segundo afirma, de tempos em tempos, retornava à casa, onde as brigas continuavam até nova fuga de Ariadne para a rua. Aos 17 anos cheirava cocaína e vivia na rua. Desse tempo, relembra que pedia dinheiro em faróis para custear o consumo de drogas e era, constantemente, assediada por homens, em situação de rua ou não.

Ariadne relata ter uma filha de cinco anos, fruto de um namorado que conheceu na rua e de quem está separada, desde que o mesmo foi preso por roubo. Atualmente tem um novo namorado fora do albergue, que a leva uma vez por mês a um hotel para terem relações sexuais mediante uma estratégia envolvendo um outro casal do albergado: "Como somos dois casais, a gente monta um plantão. Eu fico com a menina dela [da amiga] e tem uma horinha que a gente reveza e ela fica com a minha menina".

O apoio dado pelo Conselho Tutelar e pelo albergue, com a ajuda das educadoras e assistentes sociais, foram fundamentais para que Ariadne saísse das ruas e deixasse as drogas. Considera-se em processo de reabilitação para a vida.

Apesar de jovem, a entrevistada relatou problemas de saúde, como pressão alta, bronquite asmática e labirintite. 


\section{Berenice, vivendo na rua, idade não revelada}

Encontramos Berenice varrendo a calçada na Avenida Pompéia, zona oeste da cidade de São Paulo. Ao seu lado, um homem em situação de rua, aparentando aproximadamente 50 anos, permaneceu calado durante toda a entrevista.

Berenice aceitou falar conosco sem rodeios e iniciou o relato de sua história de vida dizendo-se filha adotiva de um casal de psiquiatras cariocas, atualmente separados. Cresceu em meio a brigas dos pais que nunca se entenderam.

Quando jovem, a entrevistada afirma que saía freqüentemente nas "baladas", passando noites fora de casa, dançando e "vivendo a vida". Define-se como dona de um espírito aventureiro, não compreendido pelos pais, que não entendiam seu comportamento. Começou a usar drogas e, depois de uma discussão com a mãe, saiu de casa, morando em hotéis e até mesmo em seu carro durante algum tempo. Viajou pelo Brasil e acabou por chegar em São Paulo. Na cidade, ela diz que passa o tempo andando de canto em canto, para evitar as maldades das pessoas.

Berenice exaltava-se ao relembrar episódios de sua vida e mudava a temática da conversa, sem que respondesse ao que lhe era indagado. Exceção ao fato de relatar um estupro e uma surra que levou de um homem - não conseguiu informar se este era namorado ou desconhecido. A partir desse episódio, declara ter perdido a confiança nos homens em geral. 
O depoimento de Berenice, bastante contraditório, foi fortemente marcado pelas impressões advindas da violência sofrida por ela e pelo uso de cocaína.

\section{Aglaia, idade não revelada, vivendo em albergue}

Nosso encontro com Aglaia deu-se em um abrigo que recebe mulheres em situação de rua e/ou vítimas de violência, na zona leste da cidade. A casa, sem identificação visível, busca recriar um ambiente doméstico em que convivem mães e seus filhos. Como de praxe, a assistente social levou-nos até um dos muitos quartos do abrigo, onde Aglaia, deitada em seu beliche, ouvia música. Jovem, mãe de dois filhos, ela nos recebeu amavelmente e aceitou participar da presente pesquisa. No entanto, ao relembrar os episódios passados na rua, a entrevistada chorou e, sempre que suas filhas entravam no quarto - o que ocorreu algumas vezes - ela dizia que não gostava de falar sobre seu passado perto das crianças.

Nos momentos em que conseguíamos prosseguir com a entrevista, Aglaia relatou conflitos domésticos e constantes fugas para a rua desde o inicio da puberdade. Salientando a incompatibilidade de seu modo de viver com o de sua mãe, que segundo narra, não aceitava seus namoros e sua maneira livre de viver. Na rua, envolveu-se com drogas.

Conforme depreendemos da narrativa de Aglaia, numa das vezes em que estava vivendo na rua, foi abordada por um senhor idoso que a recolheu 
junto com outras meninas de seu grupo, dando-lhes abrigo e comida por um tempo.

Nova fuga e mais uma vez na rua, acaba por iniciar relacionamento com um homem mais velho, pai de suas filhas. Segundo relata, o amor de seu companheiro foi fundamental para que Aglaia deixasse de usar drogas.

Sua vida, no entanto, sofreu o revés da morte do marido. Depois disso, a entrevistada viu-se sozinha, com filhos e sem apoio dos familiares, com quem tinha rompido laços de convivência.

Espera conseguir emprego dentro do prazo de seis meses, estipulado pela instituição para que as acolhidas reorganizem sua vida. 


\subsection{O olhar do Outro Distante sobre mulheres em situação de rua}

A pobreza se define, na acepção de Simmel (1971), "pela atitude coletiva adotada pelo conjunto da sociedade" para com os pobres, na medida em que estes passam a compartilhar de uma situação específica: o direito à assistência, seja ela real ou potencial. Assim são "as reações sociais provocadas por circunstâncias especificas" - estas últimas entendidas como carências e privações de indivíduos - que dão sentido e existência à pobreza (Simmel, 1971:150).

Com as idéias de Simmel, é possível pensar na miséria que caracteriza a população vivendo na rua, a partir das reações sociais em um sentido mais amplo, ou seja, não só em termos das mobilizações da sociedade - e por extensão, das iniciativas governamentais - no reconhecimento da necessidade de assistência aos indivíduos em situação de rua, mas também devemos observar as crenças e atitudes dessa mesma sociedade nos termos dos sujeitos que a compõem. Em outras palavras, é possível delinear um mapa que permita fornecer indícios de como essa sociedade urbana pensa a questão do morar na rua, especialmente no que tange ao olhar que tem sobre a mulher em situação de rua.

Na busca de explicações que dêem conta da complexidade do fenômeno - "o morar na rua" - alguns autores, como Giorgetti (2006), procuram olhar não somente para o universo de pessoas em situação de 
rua, mas ainda levam em conta a importância do discurso de habitantes da cidade na configuração do problema ${ }^{13}$.

Nessa linha de preocupação, interessa-nos conhecer o que pensa o grupo por nós denominado de Outro Distante, composto por prestadores de serviço - que realizam atividades em áreas próximas a agrupamentos de pessoas em situação de rua, como comerciantes e policiais - e transeuntes que passam, muitas vezes apressados, pelas ruas da cidade, e dos quais também fazemos parte. Por conseguinte, pelos relatos de membros da população urbana, poderemos ainda observar em que medida a mulher em situação de rua é reconhecida e identificada, tornando-se invisivel ou não para esta mesma sociedade.

\subsubsection{Da casa para a rua}

Uma preocupação constante em muitos trabalhos científicos nacionais e internacionais é compreender os motivos pelos quais homens e mulheres - estas especialmente pesquisadas na literatura americana e canadense -, em um determinado momento de suas vidas, deixam o ambiente familiar e passam a viver na rua. Dessa maneira, quando indagados sobre os motivos que levariam homens e mulheres a viverem na rua, a maioria dos entrevistados, caracterizados como o Outro Distante, considerou que a instabilidade das relações familiares e afetivas seria a principal causa que leva "pessoas" à rua. A seguir, foram mencionados

${ }^{13}$ Destaca-se na produção nacional, o trabalho de Giorgetti (2006), em que a autora compara as representações sociais sobre pessoas em situação de rua nas cidades de São Paulo e Paris, a partir de um universo de sujeitos composto por médicos, funcionários de instituições ligadas ao "morador de rua" e policiais. 
problemas relacionados à saúde, como sofrimento psíquico, alcoolismo, drogadição, e, finalmente, viver na rua é visto como uma opção pessoal, na busca, sobretudo de liberdade. Poucas são as referências à questão da perda ou ausência de emprego, especialmente no caso das mulheres, conforme ilustram os discursos a seguir:

"Alguns são por opção. Alguns abandonam a mulher. Teve uma colega nossa que trabalhava com a gente e foi trabalhar em um determinado local. Ela viu lá um grupo de homens de rua e quando ela pensou que não, ela deu de cara com o próprio pai dela no meio deles. Ela veio trabalhar e deu de cara com pai dela no meio dos mendigos. Imagina o choque que ela teve. Há alguns casos de doença que a gente sabe que as pessoas adquirem. E têm muitas destas pessoas que moram na rua que têm faculdade, e tem uns que chegam a ter mais de uma faculdade. De repente a pessoa teve um acesso de loucura, a familia tentou cuidar e a pessoa nada de melhorar - então se quer viver na rua, tchau!" (Jasão, guarda municipal, 47 anos).

"São pessoas que têm familia, que brigaram com as suas familias e que preferem ficar na rua. Eles vivem pedindo e preferem viver pedindo. Eles preferem pedir esmola a ficar na sua própria casa sendo ajudados por sua própria familia. Acho que é um pouco particular, mas se tentar generalizar, eu acredito, que seja que é porque eles encontram mais liberdade na rua, às vezes por falta de opção também. Mas acho que a liberdade é um ponto bem forte. Porque existem albergues que oferecem a oportunidades para eles ficarem, mas como tem algumas regras que eles acham muito chatas, eles não gostam; é 
isso que eu ouvi por alguns que eu já tive contato"(Lavínia, psicóloga, 26 anos).

"O que leva é falta de informação e a base que é a familia, as pessoas hoje que têm poder aquisitivo menor, falta de instrução e colocando bastante filhos na rua e sem condições de criá-los e a pobreza está imperando mesmo. E também tem o que eu falei, drogas, violência e isto tudo está levando, e é uma coisa que a solução é de longo prazo" (Olímpia, policial militar, 40 anos).

"Eu tive muito contato com pessoas que trabalham na rua, porque eu trabalho com comércio na rua, algumas falam que não conseguem se relacionar com a família, outros falam que o problema é financeiro" (Maia, comerciante, 47 anos).

"Eu acredito até mesmo pelo fato das pessoas que eu conheci, que o que levam elas a morarem na rua são diversos pontos: conflitos em casa. Ela não tem um bom relacionamento com os pais, com os irmãos, parentes dignos dentro de casa, então ela vai embora. Ou o pai espanca a mãe e ela entra em um nível psicótico. Eu acredito dessa forma. Ela vai embora e ela não quer voltar mais para casa. É melhor ela estar na rua à mercê dos homens e a mercê da violência das ruas do que ela estar dentro da casa dela vendo os familiares dela se matando, então esse é um fato. Outro ponto é o problema sentimental. Muitas mulheres vão embora, porque ela brigou com o namorado, acabou o seu casamento, de uma forma ou de outra tiveram o seu casamento destruído. Então elas entram em surto e vão para a rua. Elas não têm vontade de voltar para casa. Morar na rua para algumas mulheres é viver em um 
mundo de fantasias, porque na sua realidade é muito dura, então é mais fácil ela estar lá fora. Em alguns homens que a gente conheceu, eu acredito que eles vão para a rua, alguns pelo mesmo motivo, sentimental, por ter perdido a mulher, outros por ter perdido a mulher e os filhos, outros porque não conseguiram mais emprego e a sua sociedade, a sua familia acabou repudiando eles de tal forma que a única opção é estar fora de casa e não querem voltar para casa. Outros por distúrbio mesmo. A sociedade de uma certa forma os cobra com tal violência que eles preferem deixar de viver dentro de uma realidade, dentro de um grupo social que acorda todos os dias, vai trabalhar, estuda e volta para casa. Então eles preferem estar na rua" (Heitor, importador,37 anos ).

"Briga com os familiares leva, às vezes, a mulher para rua. A desestrutura na morte de alguém muito próximo, casamento desfeito de uma mulher que depende muito do marido ou um mesmo pai, alguém da família que é alcoólatra. Tem também as mulheres que são viciadas, que são alcoólatras e que também vão para rua. Homem, eu acho, que a maioria vai pelo alcoolismo por uma conseqüência de uma desestrutura familiar. Também por desemprego. O homem é mais forte ir para rua por problemas profissionais. O homem que não consegue mais ter o controle da família por falta do emprego é mais fácil ir morar na rua, já com a mulher não acontece. Eu penso que se acontece é muito difícil. A mulher se perder o emprego elas não vão ficar desesperadas e vão para as ruas" (Electra, transeunte, 41 anos). 
Conforme podemos observar, a categoria familia ganha expressão nos discursos do Outro Distante, ao que parece devido à importância atribuída pela sociedade à família como principal núcleo de socialização e como unidade básica de organização social em sentido mais amplo, a despeito das transformações vividas em relação a sua forma na modernidade. Nas palavras de Bourdieu, a família pode ser entendida como um "princípio comum de visão e de divisão, um nomos, que todos temos no espírito, porque ele nos foi inculcado por meio de um trabalho de socialização concretizado em um universo que era ele próprio realmente organizado de acordo com a família" (Bourdieu, 2005:127).

Ainda, de acordo com o autor,

$$
\begin{aligned}
& \text { "Esse principio de construção é um dos elementos } \\
& \text { constitutivo de nosso habitus, uma estrutura mental que, } \\
& \text { tendo sido inculcada em todas as mentes socializadas de } \\
& \text { uma certa maneira, é ao mesmo tempo individual e } \\
& \text { coletiva; uma lei tácita de percepção e da prática que } \\
& \text { fundamenta o consenso sobre o sentido do mundo social } \\
& \text { [e da palavra família, em particular], fundamenta o senso } \\
& \text { comum" (Bourdieu, 2005:127). }
\end{aligned}
$$

Na mesma lógica de Bourdieu, podemos considerar que é no espaço da família que se dá "todo o trabalho simbólico e prático" de recriação constante da "disposição amorosa" e "do espírito de família, este gerador de devotamentos, generosidades, de solidariedades [...], de ajuda, de visitas, de atenções, de gentilezas..." (Bourdieu, 2005:130). 
Vale lembrar que está implícito na idéia de família, além da "disposição amorosa", colocada por Bourdieu, igualmente as dimensões material e simbólica ou cultural, ou seja, de um lado, aspectos como comida e habitação, e do outro, valores e costumes. Relacionamos à concepção de familia apresentada por Bourdieu aquela de Velho, que busca entender a família na sociedade moderna, inspirado por Firth ${ }^{14}$, a partir da importância das redes de relações estabelecidas com a parentela extensa e que transcendem a idéia de família nuclear, composta por marido, mulher e filhos. Nessa linha de raciocínio, Velho afirma que, especialmente no caso brasileiro, o "universo de parentesco" é fundamental para "a elaboração da identidade dos indivíduos inseridos nesse universo" (Velho, 1987b:84).

O papel fundamental desempenhado pela família para a construção da identidade do indivíduo é visto, no caso brasileiro, também por Da Matta, quando o autor salienta a importância de se pertencer a uma família como um sinal distintivo de localização social. Afirma Da Matta:

“...tomamos a 'família' para exprimir um dado empírico e um modo de ser, bem como um valor e até mesmo uma condição de existência. Quem não tem família já desperta pena antes de começar o entrecho dramático; e quem renega sua familia tem, de saída, a nossa mais franca antipatia" (Da Matta, 1987:126).

$\mathrm{Na}$ medida em que identificamos, na fala do Outro Distante, a importância atribuída ao desligamento ou rompimento dos laços familiares

\footnotetext{
${ }^{14}$ Velho refere-se ao seguinte trabalho de Firth: FIRTH, R. e col. (1970) - Families and their relatives: Kinship in a middle class sector of London. Nova lorque, Humanities Press.
} 
como possivel causa que leva pessoas - especialmente mulheres - à rua, podemos considerar que, ao deixar a casa, homens e mulheres promoveriam, na linguagem de Bourdieu, uma quebra no círculo de reprodução social e, portanto, perderiam o referencial básico identitário, este, dado justamente pelo "ato" de pertencer a uma família. Ou, como coloca Itaboraí (2005), a ligação estreita entre valores e costumes e a manutenção do vínculo familiar aparecem ao indivíduo como uma condição objetiva de atribuição de pertencimento no mundo.

Nesse contexto, é possível situar que, no processo histórico-social brasileiro, a mulher, na família patriarcal ${ }^{15}$, ocupou o lugar de destaque como sustentáculo das relações familiares. Segundo Quintas, "o confronto do privado com o público deixa reluzir especificidades que fazem do doméstico um palco soberbamente feminino", em que "pertence à mulher a preservação, enquanto mãe e esposa, do 'ninho afetivo'”, este entendido pela esposa, marido e filhos (Quintas, 2005:53).

Cabe salientar que entre as atribuições femininas sancionadas socialmente encontra-se a expectativa de uma atuação estratégica da mulher como mediadora na convivência entre seu núcleo estrito e sua família extensa.

\footnotetext{
${ }^{15}$ Entendemos por família patriarcal, aquela que é organizada em torno da divisão sexual do trabalho, em que o homem atua como provedor e detentor de autoridade, ligado ao mundo do trabalho, e à mulher cabe a organização e unidade da vida doméstica, o cuidado com filhos e, em muitos casos, como afirma Bourdieu (2005), representa papel estratégico na tecedura das relações familiares, dos laços de sociabilidades que envolvem a família extensa, composta por irmãos, tios, primos e agregados.
} 
Apesar da família - organizada em torno do poder e autoridade patriarcal - abre espaço para a família contemporânea ${ }^{16}$, pós década de 1960, com a crescente autonomia das mulheres - decorrente, principalmente da profissionalização feminina e da conquista de novos papéis na sociedade ${ }^{17}$-, na fala de alguns entrevistados a mulher ainda aparece fortemente identificada à imagem de mantenedora da unidade familiar, responsável pela afetividade e quem, acima de quaisquer dificuldades, estaria disposta a se sacrificar pela integridade familiar, como nos relata Perseu:

“Em relação à desilusão amorosa, das pessoas que vi, a mulher parece ser mais resistente. Ela tem um laço afetivo, isso na minha opinião, muito mais forte do que homem. Porque o homem, ele tem uma, duas, três parceiras e aí vai... Já a mulher é criada para ter vínculo estável de afetividade. E quando isso não dá certo, ela resiste ao máximo. Porque vemos muitos casos de sofrimento, é a mulher apanhando e se submetendo à situação de um casamento ruim, mas ela quer manter aquele vínculo. Então, quando eu falo em desilusão amorosa e levar isso ao abandono, eu vejo isso muito mais claro com os homens. Porque a mulher vai tentar permanecer com aquele casamento, com aquela relação afetiva falida e, em outro momento, quando ela não mais conseguir, eu acho que é até natural, ela parte para um outro companheiro. Do lado profissional também vejo

\footnotetext{
${ }^{16}$ A idéia de família contemporânea, ou "familia da segunda modernidade", designa a família que se configura após década de 1960 e se caracteriza "pela crítica ao modelo da 'mulher dona-de-casa', sob a pressão do movimento social das mulheres e do feminismo; pela desestabilização do casamento, com a instauração do divórcio por consentimento mútuo e pelo crescimento da coabitação fora do casamento" (Singly, 2007:130).

${ }^{17}$ Ver, a propósito, Jelin, 1994 e Oliveira, 1996, entre outros.
} 
uma certa mudança, essa satisfação profissional, eu vejo isso muito mais do lado masculino. Pode ser meio machista, mas a impressão que eu tenho é que para mulher - não é que ela não se satisfaça com a profissão o que está em primeiro lugar para ela é uma estabilidade amorosa, familiar, social. O profissional me parece que não está em primeiro lugar. Se pudéssemos construir uma pirâmide, eu acredito, que a satisfação profissional da mulher estaria abaixo do cume. Então, eu não saberia dizer ao certo o que levaria a mulher a este estado [viver na rua]. O homem é aquilo que eu falei: é a desilusão amorosa, profissional, a falta de perspectiva, isso também incide nas mulheres, mas com a minha experiência profissional, como Policial, é difícil apontar outras causas para essa situação" (Perseu, policial militar, 35 anos).

A fala de Perseu permite revelar de que lugar ele fala, ou seja, como um não morador de rua, homem, policial. Podemos entender sua posição, a partir das afirmações de Saffioti (2004) para quem todos, homens e mulheres, são socializados dentro da ordem patriarcal de gênero, que qualifica, sanciona e opera, via cultura, expectativas de comportamento diferenciadas e distribui lugares sociais destinados a homens e mulheres no jogo de relações de poder.

Na mesma lógica, Erina, policial feminina, coloca o dilema da mulher que deseja se libertar dos condicionamentos da ordem patriarcal, mas ao fazê-lo enfrenta os limites de sua autonomia não somente por ser mulher, mas igualmente pela sua condição de classe: 


\begin{abstract}
"A mulher, ela está até deixando de lado a questão do sentimento, família e se ela está a fim de sair fora de um relacionamento e ela não tem coragem, então ela vai procurar o quê? Ela vai procurar se entregar... e uma porque às vezes o marido ameaça e acaba caindo também. Muitas delas estão aí porque não conseguiram sair fora de um relacionamento, saiu fugindo e vai morar aonde? Casou e ainda tem uns lances assim... e vai morar aonde? Na rua. Tem que saber se virar... Muitos moram na zona leste, na zona sul, na periferia e uns falam que o pai bateu, outros que o padrasto bate e por isso eles ficam na rua. Outros ficam na rua porque os pais mandam sair para pedir, o que eu não acredito - a maioria não é isto, eles vão atrás da droga mesmo e daí o que acontece?... Os mais velhos não são nem tanto a droga, mas o álcool' (Erina, policial militar, 28 anos).
\end{abstract}

Na opinião da policial, muitas mulheres vão para a rua como uma opção para fugir de relacionamentos opressivos e violentos, pois, segundo podemos depreender do relato de Erina, elas assim o fazem porque estariam "deixando de lado a questão do sentimento e da família", ou seja, rompem com o papel designado socialmente às mulheres em uma concepção patriarcal que naturaliza a condição da mesma. Nesse sentido, o pensamento de Erina nos revela ainda a aceitação e o reconhecimento do lugar ideal a ser ocupado pela mulher, como um sujeito atrelado ao universo dos sentimentos e à família, posição compartilhada por Perseu. Em contrapartida, podemos supor ainda, na fala da policial, que o abandono desse papel tradicional pela mulher e a busca da liberdade não tem uma conotação positiva, na medida em que significa a quebra da ordem 
estabelecida e, portanto, a passagem do mundo da casa - domínio do feminino - para o mundo da rua, espaço de atuação masculina. Ao buscar a rua, viver no espaço da contra-ordem, as mulheres tornar-se-iam duplamente "fora de lugar": de um lado, deslocadas da ordem por habitar o espaço da rua tanto quanto o fazem os homens - para recuperar a expressão de Escorel ${ }^{18}$ que situou os "moradores de rua" como "seres humanos fora do lugar" - e, de outro, deslocadas do espaço que Ihes foi socialmente destinado: a casa.

A questão da busca de liberdade, por oposição à opressão vivida nos conflitos familiares e na própria sociedade, aparecem de maneira enfática em mais uma fala do Outro Distante:

"Eu conversei com vários aqui. Então como não dá para viver com a familia, eles preferem se defender. Aqui, eles não têm que ficar dando satisfação e moram como quiserem. Eu acho que o morador de rua foge um pouco da sociedade também. Eles não querem viver em sociedade, porque a sociedade em si é muito cobradora, então ele não quer cobrança. E em tudo infelizmente você é cobrado. Você tem que andar de calça, a mulher tem que andar de saia e se ele quer andar de saia ou alguma coisa assim, então ele foge disso, ele não quer ser cobrado. A nossa sociedade é muito cobradora, então ele quer mais liberdade" (Orestes, porteiro,36 anos).

Em função das circunstâncias de vida, sobretudo relacionadas à dinâmica familiar, a saída de casa para a rua, segundo Orestes, surge por

\footnotetext{
${ }^{18}$ Escorel, 2006:235-236.
} 
um lado como opção de fuga de padrões sociais e, por outro, aparece como uma busca de autonomia. Em outras palavras, as mulheres, como sujeitos nesse contexto, "escolheria" viver no espaço público porque este se apresentaria como a saída possível, dadas as suas condições objetivas de existência. Além disso, é possível observar que a mulher aparece em muitos discursos como dependente da figura masculina - marido, pai, padrasto - e sua suposta liberdade na rua se limita a outras formas de dependência, como veremos no item 4.4. Observamos ainda no discurso do Outro Distante, a idéia de uma autonomia relativa da mulher que "escolhe" ir para a rua, mas não, por exemplo, a busca de um trabalho como alternativa de vida. Descola-se o campo de dependência: das circunstâncias de vida da casa - que Ihe são naturais - para novas circunstâncias de vida que the reservam o mundo da rua.

\subsubsection{Ser homem e ser mulher em situação de rua}

Nos relatos do Outro Distante identificamos a princípio, uma característica encontrada no decorrer de todo trabalho de campo com este grupo: na fala dos entrevistados, o reconhecimento da existência da mulher em situação de rua não ocorreu a priori. Ou seja, para que as mulheres fossem ao menos mencionadas, tornou-se necessário uma questão que marcasse sua existência de vida na rua: "O que você acha que significa ser homem em situação de rua? O que você acha que significa ser uma mulher em situação de rua?”. A resposta à segunda questão era construída, por vezes, em um discurso permeado por generalizações, deixando entrever que 
a mulher vivendo na rua não era uma personagem reconhecida em um primeiro olhar, como veremos no decorrer desse item:

"Os moradores de rua são grupos excluídos da sociedade auto intitulada por nós normais [...] Na nossa sociedade, nós somos criados para que maltrate o homem de rua que não é um homem bom. Até mesmo quando nós temos os nossos filhos você fala se ele se afastar, for para longe, o "homem do saco" (ou seja, o morador de rua) vai te pegar. Então isso já é imputado dentro de você, "não se aproxime do homem de rua" e o próprio homem de rua sabe que ele não pode se aproximar de uma pessoa que faz parte da sociedade, auto titulada de normais como nós. Porque essa pessoa vai te agredir, vai brigar, vai te bater..." (Heitor, exportador, 37 anos).

"[As pessoas em situação de rua] São pessoas que perderam a identidade, o lado social. A maioria não tem família ou uma familia pouco estruturada. Alguns perderam mulher, filhos, pai, mãe. Eu vejo o morador de rua como alguém perdido [...]. Eu também já conversei com uma mulher da prefeitura na questão do patrimônio da cidade no Centro, e uma das funções dela era tirar os mendigos do centro e levar para os albergues. Ela estava contando que a maioria das pessoas que trabalhavam com ela, os levavam arrastados, não era uma forma amigável. Ela disse que era comum eles bateram, empurrarem levarem a força... Que horrivel, não, é? Eu acho que as pessoas também tratam mal, porque ninguém quer tomar consciência disso. É tipo de pessoa que todo mundo no fundo gostaria que não existisse. Porque eles falam da gente mesmo, fala das nossas falhas enquanto ser humano. Eu acho que é um personagem público que incomoda pela questão dele ser 
tão marginal. É o personagem mais miserável que pode existir, então ele não pode existir e ninguém pode ver ele com bons olhos. Então o pessoal quer tratar mal, expulsar, bater. É uma tentativa de "como seria bom se você não existisse, o mundo seria melhor" (Electra, corretora, 26 anos).

Nos discursos acima, os "moradores de rua" são apresentados como excluídos, discriminados, desprovidos de identidades. Tais características remetem à obra de Goffman e ao conceito de estigma desenvolvido por este autor. Para Goffman (1988), o estigma pressupõe uma situação em que o indivíduo é considerado "inabilitado para a aceitação social plena". Segundo o autor, no mundo social, quando um estranho nos é apresentado (ou nos deparamos com ele), é possível prever uma categoria de pertencimento, de acordo com o que é estabelecido socialmente como aceitável ou não. Dessa forma, o estranho passa a ter uma "identidade social" que se desdobra em identidade social virtual - quando o estranho é preconcebido de acordo com nossas imputações - e identidade social real - quando se refere aos atributos que o estranho possui (Goffman, 1988:12).

Nesse sentido, o fato de o estranho apresentar evidência de que possui um "atributo" que o torne diferente de outros que pertencem a alguma categoria de incluídos, faz com que "deixemos de considerá-lo criatura comum e total, reduzindo-o a uma pessoa estragada e diminuída". Concluiu Goffman que "tal característica é um estigma, especialmente quando o seu efeito de descrédito é muito grande - algumas vezes ele também é 
considerado um defeito, uma fraqueza, uma desvantagem- e constitui uma discrepância entre a identidade social real e virtual" (Goffman, 1988:12).

Assim, o estigma envolve percepções e reações negativas extremas e rejeição social de um indivíduo ou grupo, como pudemos observar especialmente nas falas de Heitor e Electra, que destacamos dos relatos anteriores:

"Até mesmo quando nós temos os nossos filhos você fala se ele se afastar, for para longe, o 'homem do saco' (ou seja, o morador de rua) vai te pegar. Então isso já é imputado dentro de você, 'não se aproxime do homem de rua' e o próprio homem de rua sabe que ele não pode se aproximar de uma pessoa que faz parte da sociedade" (Heitor).

"É o tipo de pessoa que todo mundo no fundo gostaria que não existisse. Porque eles falam da gente mesmo, fala das nossas falhas enquanto ser humano. Eu acho que é um personagem público que incomoda pela questão dele ser tão marginal. É o personagem mais miserável que pode existir, então ele não pode existir e ninguém pode ver ele com bons olhos. Então o pessoal quer tratar mal, expulsar, bater. É uma tentativa de "como seria bom se você não existisse, o mundo seria melhor" (Electra).

Para Phelan e col. (1997), se a pobreza tem sido no geral, historicamente estigmatizada e, dessa forma, os pobres culpados e discriminados socialmente por sua condição, no que se refere às pessoas em situação de rua - e a miséria que os caracteriza -, a questão torna-se mais complexa, na medida em que o fenômeno - "o morar na rua" - oferece 
elementos inerentes a este tipo de experiência que induzem a atitudes de estigmatização. Phelan e col. (1997) consideram ainda que indivíduos ou grupos em situação de rua fornecem aos demais habitantes da cidade a visibilidade de seu cotidiano nos espaços públicos, a dificuldade em manter uma higiene satisfatória (o que implica uma aparência esteticamente desagradável) e, ainda, aparecem para grande parte da opinião pública, de acordo com os autores, como doentes mentais e drogados. Como concluem os autores, tais percepções são generalizadas para a população em situação de rua como um todo e, por isso, consideram-nos perigosos e, de acordo com o observado nesta pesquisa, "sujos" e "doentes" (Phelan e col., 1997:325).

“...eu tenho que usar luvas (para homens e mulheres) eu tenho familia, eu tenho uma filha que quando eu chego em casa ela meio que falta me agarrar os cabelos. Então eu tenho que pensar na saúde dela, eu tenho que pensar na minha saúde. Aquela pessoa, ela tem vários tipos de doenças, e conforme você for ao albergue, você pode verificar. Tem doenças aqui que nem se sabe o que é aquilo. Ele tem coceira, ele tem sarna, ele tem percevejo porque aqui tem vários. Então você tem que fazer uma abordagem e você tem que tirar o cachimbo, você tem que tirar a droga. Às vezes, em uma mulher, você tem que chamar uma policial feminina, e aquela mulher está menstruada, ela tem um problema de corrimento; e se ela tiver Aids?" (Jasão, guarda civil, 45 anos)

"E eles cheiram muito mal e eu não sei como eles conseguem consumir tanta droga e não se alimentar 
nada. Às vezes eles recebem comida Marmitex e eles não têm fome, eles vendem, e querem a droga, principalmente a pedra (Erina, policial feminina,28 anos).

"Ele mesmo (o morador de rua) consegue dormir com o seu próprio odor. É meio difícil, não, é? (Orestes, porteiro, 36 anos)

De acordo com Phelan e col. (1997) existe um processo de redução do entendimento do que seja de fato essa população, uma vez que a mesma passa a ser caracterizada por uns poucos "atributos" que a apresentam como uma população perigosa para a sociedade. Este fato pode ser observado na identidade construída e atribuida a homens ou mulheres em situação de rua pelo Outro Distante, em que a aparência emerge como um dado significativo ao lado de problemas relativos a enfermidades e uso de drogas.

De acordo com Sampaio e Rossi, no espaço público a questão da aparência se coloca de maneira mais pronunciada, "visto que o cidadão médio se porta diante dos outros como se fosse uma vitrina", o que pressupõe que, quando ocorre um lapso da projeção dessa imagem, as conseqüências da violação implicam nos "olhares inquisitórios dos outros". (Sampaio e Rossi, 1999: 52).

Assim, não tomar banho, não se vestir adequadamente, não cuidar das unhas, dos cabelos, dos dentes, aparece nos relatos do Outro Distante como um comportamento fora da ordem estabelecida e provoca mal estar nas pessoas que entram em contato com aquele que não pratica hábitos de 
higiene sancionados histórico-culturalmente como aceitáveis. Nesse contexto, as doenças citadas por Jasão aparecem como decorrentes das condições de vida na rua e a fala do policial indica o despreparo do mesmo para interagir com a população em situação de rua, na medida em que se identifica em sua colocação uma concepção de que se trata de uma população de risco para o mesmo, como profissional.

Para Douglas, "o reconhecimento de qualquer coisa fora do lugar na modernidade constitui-se em ameaça, e assim as consideramos desagradáveis e as varremos vigorosamente, pois são perigos em potência. Neste processo de limpeza, os perigos abrem espaço para a inclusão de uns e para a exclusão de outros" (Douglas, 1976:18).

Dessa forma, no sistema simbólico de uma dada sociedade, o papel de restaurador da ordem, que passa pela ação de (re)estabelecer padrões "normais" de comportamento, é ocupado por instituições, no caso, a Polícia. Daí encontrarmos no relato de policiais que trabalham junto às mulheres "moradoras de rua" uma expressão do olhar institucional para o que se considera na percepção dos mesmos, uma ação pedagógica em relação às mulheres vivendo em situação de rua.

"Eu falo que ela está na condição que ela está porque ela merece, ela é um lixo, e porque a melhor forma de você derrubar alguém é ferir a moral de uma pessoa. Então o que a gente usa? Eu principalmente eu falo "você é um lixo, você é nóia, você fede!" Depois eu começo a levantar a auto-estima.

"Você tem tudo para sair desta e só não sai se não quiser. Se você quiser ajuda eu tenho como te ajudar, e 
você pode ser uma pessoa limpa, ter honra, dignidade, trabalho, mas tem que sair de você". Mas antes disto eu destruo ela moralmente. Isto resolve e mexe com a moral.

Sim, porque é duro alguém chegar em você e falar que você fede mesmo! Porque até então ela está acostumada com o cheiro e a viver naquela sujeira, e é natural, e é natural porque os outros que compartilham com ela o mesmo local é igual! Agora uma pessoa de fora que não compartilha com ela o mesmo local, que não fede como ela, porque eles fedem demais e não tomam banho de jeito nenhum. Então quando você fala, fere a moral - "você é um lixo! Você tem filho? Seu filho vai ser um lixo como você! Você usa pedra? Futuro nóia!"

Elas se invocam e falam - "você fala assim porque você tem um trabalho, porque você é polícia" e então eu falo assim, que independente de eu ser polícia e de ter um trabalho, eu me amo e não quero viver do jeito que você vive jamais! Eu preferiria catar lata na rua e não justifica porquê você não tem emprego. Então emprego você catando uma lata na rua, você já tem um emprego e você não precisa estar usando droga e nem pedindo. Você não tem um lugar para morar? Para tomar um banho? Tem os albergues e você vai se levantando aos poucos.

Não, os que eu vejo são os que puxam carroça e eles puxam juntos, e geralmente não moram na rua e moram em barracos, mas as mulheres elas dormem todas juntas e enfileiradas. Nas calçadas e tudo ali fedido, usando o mesmo cachimbo, a mesma droga. É um outro mundo. Eu costumo dizer que parece que jogaram uma bomba e morreu muita gente e ficou aquele resto e dai um está querendo comer o outro vivo! Dá a impressão que você 
está em outro mundo. Tem pessoas que pensam que dá vontade de pegar uma bomba e exterminar aquele lugar lá e acabar com todos. Eu já pensei, e se eu falar que não eu estaria mentindo. Não, de vou acabar com estes nóias, vou acabar com estas drogas! Mas isto é só pensamento, e se você vai fazer isto, vai vir mais e eles vêm de tudo quanto é lado, e até no interior de São Paulo já está tendo em vários lugares e não é só aqui. Aqui tem a maior concentração porque é o centro de São Paulo. Tomou conta" (Erina, policial militar, 28 anos).

No entanto, na interpretação de Bourdieu e Passeron (1975), esse tipo de ação, que pode ser considerada "pedagógica" constituir-se-ia, pelo conteúdo que encerra, em uma típica modalidade de violência simbólica mantida pela reiteração de uma dada fala institucional que representa, no caso, a busca da ordem sobre corpos "sujos" e sujeitos "fora de ordem". A denominada "ação pedagógica", que na interpretação dos autores perpetua a violência simbólica, o faz de maneira arbitrária, em que o conteúdo da fala proferida pela policial passa a significar o poder que se instaura na relação pedagógica exercida pela autoridade socialmente legitimada, como nos apontam Bourdieu e Passeron ao afirmarem que "toda ação pedagógica é objetivamente uma violência simbólica enquanto imposição, por um poder arbitrário, de um arbitrário cultural". Nessa linha de reflexão, os autores consideram que

\footnotetext{
"as relações de força entre os grupos ou as classes constitutivas de uma formação social estão na base do poder arbitrário que é a condição da instauração de uma relação de comunicação pedagógica, isto é, da
} 
imposição e da inculcação de um arbitrário cultural segundo um modo arbitrário de imposição e inculcação [...] na medida em que a delimitação objetivamente implicada no fato de impor e de inculcar certas significações, convencionadas pela seleção e a exclusão que the é correlativa, como dignas de serem reproduzidas por uma ação pedagógica, re-produz -no duplo sentido do termo- a seleção arbitrária que um grupo ou uma classe opera objetivamente em e por seu arbitrário cultural"(Bourdieu e Passeron, 1975:20;22).

Vale lembrar que na relação estabelecida entre a voz oficial e o sujeito "fora da ordem", a mulher em situação de rua não se opõe diretamente ao seu interlocutor, numa aparente subjugação. O diálogo que se trava nessa narrativa, quando a moradora de rua responde à policial, parece demonstrar a eficácia da ideologia veiculada no discurso oficial.

"você fala assim porque você tem um trabalho, porque você é policia”.

E é imediatamente retrucada pela policial:

“... e então eu falo assim, que independente de eu ser polícia e de ter um trabalho, eu me amo e não quero viver do jeito que você vive jamais! Eu preferiria catar lata na rua e não justifica porquê você não tem emprego. Então emprego você catando uma lata na rua, você já tem um emprego e você não precisa estar usando droga e nem pedindo. Você não tem um lugar para morar? Para tomar um banho? Tem os albergues e você vai se levantando aos poucos". 
Esse diálogo passa a representar, por um lado, um processo de busca no sentido de individualizar a responsabilidade (ou "culpa") da mulher em situação de rua pela sua condição de vida ${ }^{19}$, ao mesmo tempo em que permite desvelar diferentes níveis de percepção de alteridade, ou seja, enquanto para a moradora de rua sua condição decorre de uma questão estrutural - a falta de um emprego - na qual ela assume o papel de vitimizada, para a policial o argumento é, sobretudo moral, individual, pessoal, na medida em que ignora as múltilplas determinações que o fenômeno de morar na rua encerra.

As falas da policial e de sua interlocutora revelam a discrepância existente entre a identidade social real e a identidade social virtual, na linguagem de Goffman (1988), e, no caso da mulher em situação de rua, configura uma "interação angustiada" das partes, no seguinte sentido: a mulher em situação de rua deixa de ser vista pela policial na sua totalidade e adquire o status de um ser desviante, em desvantagem em relação a ela, considerada "normal".

Numa aproximação à interpretação de Goffman em relação aos "desviantes" da ordem social estabelecida, a questão que aí se coloca é a da possível violência simbólica constante de desqualificação exercida, no caso, por Erina em relação ao que julga como incapacidade da mulher em

${ }^{19}$ Giorgetti, ao analisar como a sociedade paulistana vê e trata seus "moradores de rua", observou a "tendência dos brasileiros em transferir a responsabilidade do morador de rua ao próprio morador de rua”, especialmente observada no caso de depoimentos de policiais e médicos. Para Giorgetti, "paira no imaginário social de São Paulo a idéia de que o alcoolismo é uma escolha individual e principal fator que leva uma pessoa a morar nas ruas; logo tal fenômeno também é conseqüência de uma escolha pessoal" (Giorgetti, 2006:128). 
situação de rua para "usar as oportunidades disponiveis para o progresso nos vários caminhos aprovados pela sociedade" (Goffman, 1988:155).

\begin{abstract}
"Elas engravidam, todas; a maioria acaba engravidando, e tem hepatite, tem tuberculose, tem pessoas aqui que eu conheço há pouco mais de nove anos e tem HIV e estão só pele e osso e continuam usando droga, continuam na mesma situação" (Erina, policial militar, 28 anos)
\end{abstract}

Ainda é possível considerar que falas de desqualificação das mulheres em situação de rua não se circunscrevem aos discursos de homens - mulheres, mas igualmente, como pudemos observar, de mulheres-mulheres. Tal fato encontra explicação nas palavras de Bourdieu, quando o autor afirma:

"a força da ordem masculina se evidencia no fato de que ela dispensa justificação: a visão androcêntrica impõe-se como neutra e não tem necessidade de se enunciar em discursos que visem legitimá-la. A ordem social funciona como uma imensa máquina simbólica que tende a ratificar a dominação masculina sobre a qual se alicerça [...] é a estrutura do espaço, opondo seu local, seu momento, seus instrumentos; é a estrutura do espaço, opondo o lugar da assembléia ou de mercado, reservados aos homens, e a casa, reservada às mulheres [...] (Bourdieu, 2005:18).

Conclui Bourdieu que:

"a primazia universalmente concedida aos homens se afirma na objetividade de estruturas sociais e de 
atividades produtivas e reprodutivas, baseadas em uma divisão sexual do trabalho de produção e reprodução biológica e social, que confere aos homens a melhor parte, bem como esquemas imanentes a todos os habitus: moldados por tais condições, portanto objetivamente concordes, eles funcionam como matrizes de percepções, pensamentos e das ações de todos os membros da sociedade, como transcendentais históricos que, sendo universalmente partilhados, impõem-se a cada agente como transcendente [...] E as próprias mulheres aplicam a toda realidade e, particularmente, às relações de poder em que se vêem envolvidas, esquemas de pensamento que são produto da incorporação dessas relações de poder e que se expressam nas oposições fundantes da ordem simbólica". (Bourdieu, 2005:45)

Assim, o discurso da policial, como caso exemplar, representa a introdução de uma concepção tipicamente patriarcal incorporada via socialização - de gênero e institucional -, que de maneira tradicional acaba por discriminar a miséria - como nos demonstraram Phelan e col. (1997) - e a condição de mulher.

Outro tipo de atitude que o Outro Distante parece adotar em relação a homens e mulheres em situação de rua, pode ser identificada na narrativa de Electra:

"Geralmente não faço nada. Vira meio paisagem da rua, principalmente em São Paulo que é comum. Você olha, dá a sensação de compaixão e ao mesmo tempo de impotência. Eu fico com dó e ao mesmo tempo: O que eu posso fazer por eles? Nada! Fica uma coisa meio apática. O sentimento que você tem em relação àquela 
situação também é passageiro e passa. Sinto muito dó e uma sensação de impotência minha de não poder fazer nada por eles. Eu me sinto um pouco culpada. Eu tenho um pouco de culpa da situação deles. Como seria se eu estivesse ali? Eu penso: por que é ele que está lá e não eu? Acho que a culpa é política e econômica também. É uma falha do nosso sistema. É a coisa mais visivel e mais dolorosa de um sistema como nosso econômico e político. E isso que eu acho. O sentimento é: Olha como nós erramos. Eles provam a nossa incompetência, a nossa dificuldade em administrar um país, uma nação" (Electra, corretora de imóveis, 25 anos).

No discurso acima, o reconhecimento da existência de pessoas homens e mulheres - vivendo em situação de rua é uma questão que se apresenta, sobretudo, no âmbito politico-social. Isto porque, longe de se configurar como uma problemática individual, de responsabilidade pessoal, esta se traduz pela sua natureza e complexidade, numa responsabilidade de Estado, na medida em que se constitui numa questão estrutural a requerer políticas sociais específicas tanto de natureza econômica - como é o caso da geração de empregos -, como propriamente social.

Para utilizar o consagrado conceito de Simmel, observamos ainda no discurso de Electra o caráter blasé, que se traduz pela sua afirmação quando diz:

“Geralmente não faço nada. Vira meio paisagem da rua, principalmente em São Paulo que é comum. Você olha, dá a sensação de compaixão e ao mesmo tempo de impotência. Eu fico com dó e ao mesmo tempo: O que eu posso fazer por eles? Nada! Fica uma coisa meio 
apática. O sentimento que você tem em relação àquela situação também é passageiro e passa".

Afirma Simmel, ao tratar de características de tal atitude:

"o fundamento psicológico sobre o qual se eleva o tipo das individualidades da cidade grande é a intensificação da vida nervosa, que resulta da mudança rápida e ininterrupta de impressões interiores e exteriores. O homem é um ser que faz distinções, isto é, sua consciência é estimulada mediante a distinção da impressão atual frente a que lhe precede. As impressões persistentes, a insignificância de suas diferenças, a regularidade habitual de seu transcurso e de suas oposições exigem por assim dizer menos consciência do que a rápida concentração de imagens em mudança, o intervalo ríspido no interior daquilo que se compreende com um olhar, o caráter inesperado das impressões que se impõem (Simmel, 2005:578).

Continua ainda o autor:

"A essência do caráter blasé é o embotamento frente à distinção das coisas; não no sentido de que elas não sejam percebidas, como no caso dos parvos, mas sim de tal modo que o significado e o valor da distinção das coisas e com isso das próprias coisas são sentidos como nulos. Elas aparecem ao blasé em uma tonalidade acinzentada e baça, e não vale a pena preferir umas em relação às outras (Simmel, 2005:581).

Conclui Simmel:

"Assim, o tipo do habitante da cidade grande - que naturalmente é envolto em milhares de modificações 


\begin{abstract}
individuais - cria um órgão protetor contra 0 desenraizamento com $o$ qual as correntes $e$ discrepâncias de seu meio exterior o ameaçam: ele reage não com o ânimo, mas sobretudo com o entendimento, para o que a intensificação da consciência, criada pela mesma causa, propicia a prerrogativa anímica. Com isso, a reação àqueles fenômenos é deslocada para o órgão psíquico menos sensível, que está o mais distante possível das profundezas da personalidade. Essa atuação do entendimento, reconhecida portanto como um preservativo da vida subjetiva frente às coações da cidade grande, ramifica-se em e com múltiplos fenômenos singulares" (Simmel, 2005: 578).
\end{abstract}

Assim, a atitude blasé do Outro Distante se nos apresenta, ao que parece, como uma típica representação da naturalização de uma realidade social de exclusão vivida pelo "morador de rua". Na interpretação de Simmel, esta se colocaria como forma de defesa dos problemas sociais na percepção das diferentes camadas sociais frente ao fenômeno da exclusão e da miséria a que muitos "cidadãos" estão submetidos no mundo contemporâneo. É nesse sentido que podemos pensar na invisibilidade da mulher e do homem vivendo em situação de rua.

A fala de Cassandra exemplifica tal constatação:

"A gente acaba acostumando com essa situação. Acaba sendo natural. Eu passo reto e tudo bem, infelizmente" (Cassandra, psicóloga, 26 anos). 
Se por um lado em discursos do Outro Distante, como o de Cassandra, revela-se a existência de estigma e naturalização, a percepção do mesmo não se reduz a esse tipo de olhar:

\begin{abstract}
No passado, até por não tê-las conhecido, eu atravessaria a rua por medo, total desconhecimento. Hoje eu passo, não mudo de calçada, e se houver a possibilidade, haver a abertura dela no simples passar na rua, cruzar com elas na rua, eu tento conversar, se eu estiver comendo eu ofereço comida, se eu tiver roupa no momento, oferecer uma roupa e dou uma palavra amiga" (Heitor, importador, 37 anos)

"São seres humanos iguais a nós. Pessoas iguais à gente que deve ter acontecido alguma coisa na vida, para que eles fiquem assim na rua...Elas não vivem bem porque elas vivem sem higiene, são pessoas sujas, humilhadas. Eu já vi a prefeitura vir e tirar eles da calçada. Pessoas que estavam dormindo de madrugada, jogam até água no lugar que eles dormem. Então, eu acho que isso é muita humilhação"(Maia, comerciante, 47 anos).
\end{abstract}

Em situações em que o olhar blasé dá lugar a um reconhecimento de um drama social vivido por pessoas em situação de rua, a sensibilização observada nos relatos dos transeuntes, Heitor e Maia, incorpora os sentimentos de igualdade na diferença e solidariedade que, na linguagem de autores como Touraine (1997) e Milovic e col.(2005), deveria se constituir, ao lado da democracia, como traço característico do Estado democrático. 


\subsubsection{Relações de gênero na perspectiva do Outro Distante}

O cenário da rua impõe desafios de toda ordem, especialmente aqueles que dizem respeito às experiências de vida tipicamente relacionadas à dimensão da intimidade e, portanto, da vida privada, como o caso das relações afetivas e conjugais entre homens e mulheres. Nesse sentido, a questão básica a ser compreendida consiste em saber como o Outro Distante pensa essas relações quando vividas no mundo da rua:

"Você vê mais o grupo maior de homens, e geralmente você vê uma ou duas mulheres no meio deles, e quando você vê uma ou duas mulheres você vê que estão em uma situação deplorável. Deplorável é ela usar, ela se embebeda de cá, usa droga de lá, e é sexo, droga e tudo aquilo misturado... As mulheres, dependendo da situação, elas até se prostituem com os próprios albergados e é uma maneira de ter dinheiro para suprir a necessidade da pinga, do cigarro e às vezes até das drogas. Algumas têm filhos e deixam os filhos com a mãe e o pai em outro estado e vêm aqui tentar a sorte, e se não conseguem, vão viver até adquirir uma doença. $E$ elas apanham dos homens na rua, apanham de outras mulheres. Então isso vira um círculo vicioso e depois elas não conseguem mais sair e até ir à decadência e até morrer" (Jasão, policial militar, 47 anos).

"Que pergunta difícil! Eu acho que é mais difícil para a mulher do que para o homem, porque elas sofrem mais violência. Eu acho que a maioria delas têm filhos precocemente, isso até pela solidão. Tem filhos com os caras que conhece nas ruas. Geralmente os relacionamentos duram pouco e além de ficarem 
desamparadas elas ainda tem os filhos... (Electra, corretora de imóveis, 25 anos).

"Eu acho que para a mulher é mais delicado viver na rua, porque tem a questão da violência que acaba afetando, o homem querendo ou não ele acaba se defendendo melhor do que a mulher. A mulher fica lá, na minha cabeça, sei lá, mas que ela pode sofrer algum abuso, alguma coisa assim. Tem as delicadezas femininas como a menstruação, acho que deve ser difícil... É isso que eu estava falando mesmo, acho que para mulher é mais difícil. A mulher tem que se proteger mais, tem que escolher melhor onde ficar. Para a mulher é sempre mais delicada essa situação na vida. É o que eu falei agora: é o problema da vivência e das particularidades femininas (Lavinia, 26 anos).

"Na situação de rua eu acho que existe muito a violência sexual, a violência material e os problemas, de tudo. A mulher, sexualmente falando, assim, melhor, corporalmente falando a mulher tem mês que tem o período dela que ela precisa de cuidados, doenças que ela adquire com mais facilidade na rua, falta de higiene, e elas são abusadas... elas convivem com isto e o abuso para elas torna-se até uma coisa normal, é a promiscuidade na rua; e ela está bem louca ou drogada, alcoolizada e dormindo com um monte de homem, rola mesmo... de repente, ela muitas vezes, ela nem viu quem foi e com quantos foram, entendeu? E tem o lado, como eu vou te falar, as doenças que adquire por não se cuidar, por não fazer uma prevenção e para ir a um posto de saúde. Ela vai e não usa uma camisinha, não toma um remédio, não faz um Papanicolau, então é complicado isto... Existe uma violência entre eles e se 
batem, um bate no outro, um briga com o outro e isto acontece muito, mas depois eles voltam a ficar tudo bem... Já vi mulher bater em homem e homem bater em mulher, discussão bastante. Você querendo ou não eles têm sentimentos da forma deles e no mundinho deles e então brigam por causa de ciúmes e um briga com o outro porque ele olhou para a minha mulher e pode ser a mulher mais feia, mais estragada do mundo, mas ele ama e acabou. Mas isto acontece bastante entre eles" (Olimpia policial militar, 40 anos).

Nas relações de gênero, vistas no cenário da rua pela ótica do Outro Distante, a mulher aparece em meio a um universo social predominantemente masculino, perpassado pelas mais diversas formas de violência, pelo alcoolismo, pela drogadição, prostituição, por enfermidades e pela falta de condições básicas de higiene e saúde. Nesse contexto, os entrevistados revelaram a rua como o espaço da degradação da mulher. É na rua que o corpo feminino torna-se, em muitos depoimentos, moeda de troca por droga ou cigarro, como a narrativa de Jasão; é na rua que a mulher adquire doença, sofre violência e abusos de toda sorte, tem filhos nascidos de relacionamentos ocasionais, enfrenta as dificuldades de cuidado com o próprio corpo e torna-se parte de "um círculo vicioso" que culminaria, como ainda afirma Jasão, com sua morte.

O relacionamento entre homens e mulheres na rua não são reconhecidos como uma escolha recíproca, baseada em critérios afetivos, sexuais e na noção de amor, presentes segundo Velho (1986), na constituição da família contemporânea. De maneira contrária, no 
entendimento do Outro Distante, a vitimização e a passividade feminina no mundo da rua, em relação ao homem, parecem patentes na mesma medida em que as uniões são concebidas como fortuitas, muitas vezes tendo como mote a obtenção de droga e/ou proteção.

Se comparadas às relações conjugais pautadas por valores como o amor e o individualismo ${ }^{20}$, observados por Velho (1986) nas camadas médias cariocas, a rua surge, no imaginário do Outro Distante, como o mundo da inversão social, em que as regras sociais são abandonadas ou (re)signifcadas, mas no qual, ao mesmo tempo, amplia-se a relação assimétrica e desigual entre a força masculina e a suposta "natureza frágil da mulher":

\begin{abstract}
"A mulher sempre é o sexo frágil e na rua ela é o sexo mais frágil ainda. O homem é sempre o sexo forte, é onde ele tem o poder, mesmo estando na rua e ele abusa dessa condição de ser o sexo forte. Ele abusa dela sexualmente, faz ela trabalhar, se tiver que trabalhar pedindo dinheiro na rua, ou até mesmo roubando que é essa a situação de trabalho deles, então elas são obrigadas a fazer isso... O homem como força, é a própria força física dele mesmo. Em experiências que eu tive com pessoas que moram na rua, se a mulher não obedecê-lo, ir até um farol e pedir comida, pedir dinheiro, ou realizar pequenos furtos em feiras e trazer o alimento para ele que fica em um determinado ponto, elas apanham. Em alguns casos elas são estupradas, eles
\end{abstract}

\footnotetext{
${ }^{20}$ Inúmeros autores têm buscado compreender o individualismo da sociedade moderna. Sobre essa temática, salientamos, como Velho (1986), as obras de Simmel (2005). De uma maneira geral, citamos Velho, para quem o individualismo pode ser entendido como "uma valorização, ao nível da representação, da ideologia, do individuo biológico como sujeito, unidade mínima significativa da vida social" (Velho, 1986: 24).
} 
têm um grupo de pessoas, de homens, que se determinadas mulheres não obedecerem aquilo que eles estão pedindo elas são estupradas. Então, com medo disso, sem uma opção melhor de sair daquele mundo e ir para uma situação melhor, elas acabam se sujeitando a isso" (Heitor, 37 anos, importador).

"A maioria, a grande parte delas são violentadas porque estão na rua, então elas até acabam se envolvendo com os marginais para poder ter uma garantia de que ninguém possa mexer com elas. Uma grande parte delas também é soro positivo, a maioria...Sim, proteção, senão todos vão pegar, todos vão querer estuprar. ... Elas acabam conhecendo porque um acaba falando para o outro e na rua você acaba conhecendo só o que não presta. Aí vem um grandão e fala assim - "se você quiser ficar bem no lugar, aqui ou no pedaço, você tem que ficar comigo" - então ela acaba ficando e não por vontade, mas para ter uma proteção e ficar usando a droga dela e ter uma proteção de alguém. Como se fosse um cafetão, mas não seria um cafetão, porque ela não vai estar se prostituindo, mas ela vai ter a garantia dele de que ninguém vai pôr a mão (Erina, policia militar, 28).

No quadro delineado pelos entrevistados acima, a mulher constrangida pela força física masculina até as últimas conseqüências, muitas vezes é acompanhada por crianças que passam a viver em meio à violência, conforme nos relata Jasão:

"Há dez dias foi desligado um casal daqui, e tanto o homem como a mulher eram duas bestas humanas que infelizmente tinham duas crianças para suportar toda a carga negativa deles. Geralmente, quando ela é 
abandonada na rua com filhos, ela arranja um parceiro e aquele parceiro faz o que quer e judia dela e das crianças, mas como ela é a fêmea e ele é o macho, ela não quer perder o macho, então é uma série de fatores. Por mais que você tente esclarecer, é perda de tempo" (Jasão, policial militar, 47 anos).

No relato de Jasão, manifestam-se, o que Ramirez (1995) denomina como "ideologias masculinas" - partilhadas por homens e mulheres presentes em sociedades que se estruturam com base em relações assimétricas de gênero, articuladas em forças e jogos que exibem a multiplicidade de suas manifestações em diferentes níveis. Nesse sentido, podemos observar como discursos masculinos são construídos com a intenção, consciente ou não, de subordinar a mulher e desvalorizar a esfera do feminino, atrelando à mesma o peso da responsabilidade de sua própria condição e da condição de outros, no caso de seus filhos. Assim, a rua se configura, no olhar do Outro Distante, como um local privilegiado para a existência do que Bourdieu (2003) denomina de "pleno exercício" da dominação masculina.

Em um universo de regras e valores masculinos, em que a masculinidade parece ser garantia de sobrevivência, algumas mulheres parecem assumir na rua tais valores como mecanismos de autoproteção e estratégias de vida:

"É diferente, mas elas usam da força braçal. Para morar na rua tem que encarar, então elas se defendem, se acham homem também" (Orestes, porteiro, 36 anos). 
Dessa forma, nos relatos do Outro Distante sobre a mulher em situação de rua, a mesma é descaracterizada, no geral, como sujeito social autônomo porque aparece representada no imaginário social de maneira naturalizada, como um ser frágil, incompleto, deslocada de seu locus - a casa -, essencialmente dependente da "força masculina" e sujeita a toda sorte de violência física e simbólica.

A análise dos discursos permite, ao que parece, desvelar o ideal feminino implícito nesse mesmo imaginário social que reduz e ignora as conquistas das mulheres observadas em nossa sociedade, em diferentes níveis e grupos sociais.

Embora o Outro Distante, por vezes, vislumbre uma autonomia feminina relativa quando entende, por exemplo, a saída da casa para a rua como uma opção ou fuga de uma dada situação familiar, a força da dominação masculina parece acentuar-se no mundo da rua, desconsiderando a flexibilização das relações de gênero, observadas por Giddens (1993) na sociedade moderna que redimensionaram de maneira efetiva o papel da mulher na sociedade. Se no Brasil, a mencionada flexibilização nas relações de gênero pode igualmente ser observada em muitos contextos, isso não exclui o que Saffioti $(2004 ; 2005)$ identifica traços remanescentes do patriarcado em nossa cultura.

\subsubsection{Da rua para a casa: um caminho possível?}

Grande parte das políticas públicas direcionadas a população de rua, em geral, enfatiza a necessidade da saída do indivíduo da situação de 
vulnerabilidade extrema, representada pela vida na rua. É nesse sentido que o poder público pensa em albergues, casas de convivência e moradias provisórias que representariam o espaço de mediação entre a casa e a rua.

Em muitos casos, iniciativas oficiais e não governamentais investem no custeio de recursos para "embarcar" o "morador de rua" rumo a sua terra Natal, na esperança de que reintegrados à família de origem, estes reatem os laços rompidos e, com isso, retomem seu lugar na sociedade. Parte desse raciocínio, a nosso ver, explica-se nas idéias até aqui expostas que procuraram demonstrar o papel ontológico da família brasileira, para recuperar expressão de Sarti (1996), como aporte de sobrevivência material e simbólica.

Em nosso universo de pesquisa, quando indagado sobre as possibilidades de homens e mulheres deixarem a rua, "o Outro Distante" trouxe uma visão fatalista da situação e oscilou entre a tendência, já identificada por Giorgetti (2006), de responsabilizar o morador de rua por sua situação e, ao mesmo tempo, creditar à família e ao Estado o papel de agentes mobilizadores de recursos para a "solução" do problema:

"Eu vejo [saída], mas não de sair da miséria e sim da rua. De repente se for morar numa casa vai ser numa situação muito precária e numa situação financeira muito ruim. Elas podem sair da rua, mas não da situação de margem... até mesmo para um morador de rua, hoje é difícil ele acreditar que uma pessoa vai estender a mão para ajudá-lo" (Electra, corretora de imóveis, 25 anos).

"Se falar que precisa de ajuda de uma clínica, clínica não resolve muito não. Eu já tive o problema dentro da 
familia e amigos e arrumei várias clínicas até para internação, mas eles acabam voltando. $90 \%$ das pessoas que são internadas em uma clínica voltam. $O$ que mais se precisa para uma pessoa desta de rua é amor, a família tentar a recuperação" (Erina, policial militar, 28 anos).

"É meio complicado e foi o que eu te falei, eu acho que o governo tem condições sim, mas eu vejo como um descaso. Eu acho que teria que fazer um trabalho muito grande e não é só tirar da rua e tem que ser encaminhado para um psicólogo, uma desintoxicação, você entende? Então não é só tirar da rua, a rua é fácil, e tem que fazer uma manutenção desta retirada, um acompanhamento médico, psicológico, porque senão vai voltar para a rua de novo. Foi o que eu te falei que é um ciclo vicioso e o espirito já está ali, o espirito está na rua e ele tem que se tratar e não é só o corpo, mas a cabeça, a mente. Eu vejo um trabalho assim, não vejo uma luz no fim do túnel, infelizmente eu não consigo ver e acho que sempre vai ter [pessoas vivendo na rua]" (Olimpia ,policial militar, 40 anos).

O conteúdo dos discursos acima vai ao encontro da complexidade do fenômeno, já observado por Alvarez, que se apóia na concepção de Edgar Morin, onde estão imbricados aspectos psico-afetivos, econômicos e sociais que extrapolam iniciativas isoladas e apontam para a importância de políticas sociais integradas, voltadas para as especificidades desse grupo social (Alvarez, 1999; 2003).

Apesar de apontarem nessa direção, as falas de Electra, Erina e Olímpia, mostram que estas esperam do Estado, da família e do próprio 
"morador de rua" a "solução" para a saída de homens e mulheres do mundo da rua. A responsabilidade da sociedade civil - e da qual as entrevistadas fazem parte - ou supostas formas de atuação desta, não são mencionadas nos discursos analisados.

Especialmente em relação ao papel da família de origem, no que diz respeito à saída dos indivíduos da rua, e o esperado apoio desta àquele que retorna, parece nos que a retomada dos laços familiares não depende unicamente do retorno físico do indivíduo ao antigo ambiente da família, mas de ações envolvendo Estado, sociedade civil e o "morador de rua", no sentido de permitir ao indivíduo existir no mundo enquanto sujeito, na acepção de Touraine (1997), como veremos a seguir.

Em última análise, a nosso ver, trata-se de incluir a problemática do "viver na rua" no contexto da sociedade democrática na modernidade tardia e responder a uma questão, exposta por Touraine (1997) em relação aos dilemas sociais do nosso tempo: como combinar o reconhecimento das diferenças - que pressupõe a liberdade de cada sujeito - e a afirmação de um princípio universalista de igualdade entre os indivíduos - garantindo o "direito de todos os seres humanos a darem um sentido a sua existência" - ?

Touraine afirma que o direito de todos os seres humanos a darem um sentido a sua existência impõe a todos [grifo nosso] um dever de solidariedade, esta vista como "um meio de dar a cada um autonomia e segurança sem as quais não se pode construir um sujeito". É, portanto, a partir da criação de novas estratégias de solidariedade que o autor pensa resgatar as condições que permitam ao indivíduo "ser o ator de sua própria 
história". Somente dessa maneira, conclui Touraine, o indivíduo se define novamente por aquilo que faz, por aquilo que valoriza e pelas relações sociais nas quais se encontra engajado (Touraine, 1997:193).

Nesse contexto de discussão, o desafio que se coloca em relação à população vivendo na rua pode ser pensado nos seguintes termos: como fornecer à pessoa em situação de rua condições que lhe garantam a "possibilidade de escaparem aos determinismos sociais" - e, com isso, terem a oportunidade de viabilizar condições objetivas para existirem no mundo - e de construírem seus projetos pessoais, agindo de acordo com os mesmos?

Quaisquer que sejam as eventuais tentativas de respostas à indagação acima, estas requerem, de maneira explícita, uma integração fundada nos principios da solidariedade, entre sociedade civil - incluímos aqui também a família -, políticas públicas e pessoas em situação de rua, com o intuito de resgatar, como propôs Touraine (1997), a unidade do indivíduo ou ainda, segundo Alvarez (2003), de promover o encontro do indivíduo com o sentido de sua vida.

Tal integração solidária tríplice pressuporia ainda considerar a necessidade primordial de reconhecer a existência social de mulheres vivendo na rua, com suas especificidades e demandas. 


\subsection{O olhar dos homens - o Outro Próximo- sobre mulheres em situação de rua}

\subsubsection{Da casa para a rua}

Da mesma maneira que transeuntes e prestadores de serviço - o Outro Distante - foram indagados sobre os motivos que levariam mulheres e homens a irem para a rua, os homens em situação de rua - o Outro Próximo - assim responderam a mesma questão:

"[Sobre as mulheres na rua]... Crise em casa, separação. Ou seja, negócio que não deu certo e desanimou ou até mesmo se atiraram nos vícios e perderam tudo. Pode ser a familia, o marido, o trabalho, a atenção dos parentes...isso eu acho que leva elas a estarem na rua...[Em relação aos homens] os mesmos motivos. Separação, desemprego..." (Hades, vivendo na rua, 34 anos).

"[Mulheres vão para as ruas] por problemas de família ou financeiros. Às vezes a menina engravida e a mãe não quer e coloca para fora...aí elas vêm para a rua" (Dioniso, vivendo na rua, 42 anos)

"Desemprego, maus tratos por homens..." (Ares, vivendo na rua, 27 anos).

"Muitos problemas, brigas de família. Eu estou na rua por causa de briga de família, eu me separei da minha mulher e é por isso que eu estou aqui, senão não estaria... [sobre a presença de mulheres na rua] Elas não têm uma pessoa que seja responsável por elas. Elas vivem nas ruas por isso" (Aquiles, vivendo na rua, 49 anos). 


\begin{abstract}
"Você vê que uma mulher que ela tem tudo para não ficar na rua... Por ser mulher e é mais fácil dela arrumar um emprego, mas elas não querem e ela se acostumou nesta vida aí de pedir e o pior problema é você se acostumar com o pedir, porque o dinheiro vem fácil, vai para droga... Vai fácil e ela fica naquilo. E se não chegar ninguém para dar uma força para ela, ela vai ficar mendigando o resto da vida" (Hérakles, vivendo na rua 37 anos)
\end{abstract}

Nos depoimentos acima, de uma maneira geral, é possivel perceber a rua como o local de encontro dos seres humanos "caídos", para usar uma expressão de Vieira e col. (2004), independentes de serem homens ou mulheres. Segundo os homens entrevistados, as razões para tal fenômeno encontram-se ligadas à macroestrutura - como desemprego - e à microestrutura - drogas, álcool, falta de apoio familiar ou rompimento com cônjuge, sendo estes vistos como contingências individuais.

A análise de tais discursos permite-nos identificar a presença de uma suposta igualdade de gênero, explicitada nas falas de Hades e Hélio, quando estes colocam homens e mulheres como "vítimas" das mesmas circunstâncias, envolvendo em diferentes níveis a macro e a microestrutura. Em contrapartida, com as narrativas de Dioniso, Ares, Hérakles e Aquiles podemos reconhecer questões típicas do mundo feminino que "explicariam", nas falas dos entrevistados, as razões que levam mulheres à rua, diferentemente de homens: gravidez, violência doméstica contra a mulher e necessidade de "tutela" (por serem mulheres). 
Chama-nos a atenção o depoimento de Hérakles, para quem o estar na rua, muitas vezes, aparece como uma opção das mulheres, visto que o fato de ser mulher traria facilidades no momento de encontrar trabalho fora da rua. Portanto, viver na rua seria uma escolha pessoal e um traço distintivo para a mulher nessa condição, uma vez que neste discurso, o homem seria impelido à rua por razões externas a sua vontade. Na mesma linha de raciocínio, a mulher que vive na rua, segundo nosso entrevistado, acostuma-se a pedir, gasta tudo o que consegue obter com drogas e entra, finalmente, em um círculo vicioso do qual dificilmente sairá, sem auxilio. A fala de Hérakles ainda é reveladora da ambigüidade presente no seu olhar sobre a ida da mulher para a rua e sua permanência nesta. Isso porque, se por um lado, esta se apresenta em um primeiro momento como uma opção da mulher - indicativa de um certo grau de autonomia da mesma -, por outro, sua permanência nesta condição a coloca em uma situação de maior fragilidade e dependência extrema em que a mesma se vê altamente vulnerável às drogas e à mendicância. Em sua visão, Hérakles não somente essencializa a natureza feminina, mas a despoja de sua condição de sujeito.

A narrativa de Hélio, como alguém que já dormiu nas ruas e agora se encontra em um albergue, aponta para a distinção existente entre a vida na rua, vista do albergue, e aquela vivida nas calçadas, em que a droga aparece como um elemento inerente ao cotidiano na rua, para homens e mulheres, em toda a sua diversidade. Neste caso, ao lado de multiplicidade de razões que levam mulheres e homens ao mundo da rua, vale destacar a 
presença de diversas drogas como sendo um dos motivos da ida para a rua e também razão de permanência na mesma:

"e tanto faz o homem como a mulher, é a mesma coisa, porque quando a pessoa chega nesta situação algum motivo ele teve para chegar a este nivel, mas só que quando ele passa na rua mesmo, daí é muito diferente de quem está aqui no albergue. Quem está aqui dentro ele tem uma visão, mas agora quem está na calçada tem outra, e é complicado isto daí. É complicado a pessoa amanhecer o dia embaixo de quatro telhas ou estar embaixo de um papelão e não dá nem para analisar esta situação. Mas só que muitas pessoas que caem neste exato momento - e tanto faz homem ou mulher-, mas alguns é falta de emprego, outros é falta de apoio da familia e outros são ex-presidiários que a familia não aceita mais dentro de casa porque cometeu um erro, e muitos é por causa de droga. Esta que é a pura verdade. Quando é só o álcool ainda tem o retorno, mas quando tem droga no meio é complicado. A droga - quando o usuário usa só a fumaça ele está usando só uma droga, mas se ele usa o pó, que é a cocaína, então ele está usando duas. Se ele usa crack, que é a pedra, ele usa três. Se ele usa a pinga são quatro. Se ele usa comprimidos, alguns que endoidam mesmo, como Optalidon, Pletil com cachaça ou coca é 24 horas no ar direto. Lança-perfume e ainda existe esta droga toda aí. Então o que acontece? Cada um tem um motivo, sendo que quando o ser humano, se ele tem algum vício desses e ele quer parar e voltar à situação que era antigamente, com a ajuda de outras pessoas ele volta..." (Hélio, vivendo em albergue,49 anos). 
Vale mencionar que, nos últimos anos, pesquisas têm apontado para a presença significativa de drogadição entre a população de rua, como por exemplo, o trabalho de Nyamathi e col. (2004) sobre o uso de drogas na população feminina de rua em Los Angeles. Os autores encontraram 50\% de mulheres em situação de rua que admitiram usar ou ter usado substâncias ilícitas. Segundo Nyamathi e col. (2004), mulheres em situação de rua consideradas dependentes do uso de drogas, apresentaram quadros psicológicos de depressão, ansiedade, vitimização (em relação à violência e hostilidade pública), baixa auto-estima e menor envolvimento com redes sociais de apoio.

No Brasil, não há estudos específicos sobre o uso de drogas e suas implicações psico-sociais entre mulheres em situação de rua. Porém, em nossa pesquisa são freqüentes as menções ao uso de crack e álcool nas entrevistas de homens e mulheres. Nesse sentido chamamos atenção para a recente magnitude da questão e suas implicações na vida cotidiana de homens e mulheres que vivem na rua.

Para Vieira e col., se a rua pode simbolizar a agonia e a morte social, o álcool (e por extensão as drogas) "pode ser interpretado como um analgésico que possibilita ao indivíduo liberarem-se dos códigos" e, ao mesmo tempo, permite aos habitantes da rua "entrarem num mundo imaginário que afaste, pelo menos por curtos espaços de tempo, as pressões sociais". Sendo assim, o álcool (e as drogas) atuaria como "um mediador que torna possível o desligamento do mundo das obrigações, dos papéis sociais e o mergulho num outro plano de realidade, que afasta a 
percepção do fracasso, faz esquecer dores e decepções, enfim, torna suportável o cotidiano" (Vieira e col., 2004:102).

Se essa visão trazida por Vieira e col. pode representar um aspecto da relação da população de rua, onde o uso do álcool pode ser visto, segundo Varanda, como uma modalidade de sociabilidade que envolve indivíduos e grupos, o mesmo não acontece com drogas como o crack. A idéia presente é a de que a entrada e disseminação de drogas ilícitas, especialmente o crack na realidade paulistana, parecem alterar substancialmente a dinâmica das relações no mundo da rua. Isso porque o crack, pelas suas características, envolveria maior dependência física e psíquica, perda de autonomia, sendo associado ao aumento da criminalidade, como revelam sugestivos depoimentos de sujeitos entrevistados por Alvarez em dois estudos longitudinais (1999;2003), em que mudança de tal dinâmica pode ser observada pela autora, na profundidade das histórias de vida de dois entrevistados, Cara Queimada e Soviético.

Além disso, o uso de álcool (e drogas) ainda pode ser visto segundo Varanda, "nas rodas de pinga que se formam nas ruas, a bebida assume uma funcionalidade diversificada e se insere nas redes de relações sociais, justificando-a e mediando-a". Conclui Varanda, "as relações de poder e as relações interpessoais estão reproduzidas nestes grupos como em qualquer outro, entretanto, o poder econômico, o jogo de influências, a liderança e as conversas se canalizam através da bebida, tornando-a o grande mediador e indispensável no setting dos grupos de rua que vivem fora das instituições sociais" (Varanda, 2003:61). 
Ao lado das colocações acima de Vieira e Varanda, vale observar que o mundo da rua pode ser entendido como um espaço-mercado propício para venda e uso de drogas ilícitas, especialmente o crack, no contexto brasileiro.

Assim, drogas e álcool podem ser interpretados em termos de aspectos característicos desse mundo, em que homens e mulheres escrevem suas histórias de vida como seres que passam, ou que nele permanecem num processo de identificação e (re)socialização.

\subsubsection{Ser mulher e ser homem em situação de rua na perspectiva do Outro Próximo}

Ao analisar o ponto de vista dos homens em situação de rua sobre mulheres nessa condição, é possível inferir que comportamentos atribuídos às mulheres aparecem no discurso masculino como se fossem determinados e decorrentes da conformação biológica feminina. Assim, alguns atributos que definem o que é ser homem e o que é ser mulher em situação de rua aparecem inexoravelmente ligados ao que homens entendem ser a natureza de ambos, conforme o discurso de Hermes:

"Mulher é mulher, e homem é homem. A mulher tem mais facilidade na situação de rua. Para o homem é mais correria, mas faz parte da vida do homem isso mesmo...No fator trabalho. A gente pega a carroça. A gente vai buscar material para a reciclagem. Enquanto isso a mulher é a mulher. A mulher não tem que fazer nada. Ela tem que ficar ali quietinha só, mas mesmo 
assim ela dá uma força" (Hermes, vivendo na rua, 44 anos).

Ainda dentro da lógica do discurso masculino em questão, observamos que o lugar reservado ao homem na dinâmica social é o de exercer o papel ativo, de "fazer correria", e, à mulher, lhe é dado o papel passivo, secundário, de acompanhar o dinamismo masculino sem interferência, ficando "ali quietinha só". Mesmo assim, sem atitude alguma, conclui Hermes: "ela dá uma força".

Não somente na fala de Hermes, mas em outros relatos de homens em situação de rua é possível ressaltar, de uma maneira geral, que supostas particularidades de gênero são percebidas a partir do tratamento diferenciado dado a homens e mulheres pelo Outro Distante. O que homens, como Adonis, entendem ser o comportamento do Outro Distante apresentado aqui como representante da sociedade e de seus valores - em relação à população em situação de rua, parece orientar a percepção dos homens entrevistados sobre o que é ser mulher e ser homem na rua.

"Elas são tratadas com mais respeito. O homem nessa situação a própria Militar descrimina muito, principalmente se for jovem, se tiver entre 20 e 28 anos, sempre vão ser vistos como bandido, como vagabundo. Eles acham que a gente tem condições de trabalhar e não estamos trabalhando. Eles sempre alegam isso. Os homens nessa situação são mais discriminados do que as mulheres... As mulheres não são mal tratadas, raramente alguém rela a mão em uma mulher. A Polícia raramente está corrigindo uma mulher, e os homens se 
forem abordados de madrugada na praça apanha, juntam quatro ou cinco e espanca. Quando não, eles jogam água gelada, pegam os cobertores e botam eles para sair correndo. Isso que acontece com os homens" (Adonis, 23 anos).

A complexidade das relações sociais no mundo da rua revela-se, em relação à mulher, de maneira exemplar ainda na fala de Adonis, quando observamos que a violência e o estigma que caracterizam, no item anterior, a atitude do Outro Distante em relação à mulher, pode tornar-se imperceptível ao olhar dos homens em situação de rua. Assim, a idéia de "ação pedagógica" exercida pelo olhar institucional da polícia, observada na fala de Erina, não é reconhecida, por exemplo, pelo entrevistado.

O tratamento diferenciado concedido à mulher, e identificado por Adonis, no discurso acima, é reiterado, adiante, por Hefesto, que o considera "natural". Na fala de Hefesto, observa-se igualmente a falta de percepção sobre a violência a que mulheres em situação de rua estão expostas.

Ressaltamos que a violência contra a mulher somente aparece nas falas dos homens, quando se indaga a respeito das relações afetivas e conjugais, como veremos em item posterior. Isso aponta para o fato de que o desvelar de fenômenos complexos, ou seja, fenômenos com diferentes níveis de realidade, nem sempre perceptíveis ao olhar do senso comum, tem no ato da fala do entrevistado, a exemplo do que identifica Gregori (1993) quando analisa as queixas de mulheres, um ritmo e uma temporalidade que vão progressivamente revelando novos contornos e nuances do mesmo, mostrando a ambigüidade do discurso vitimizado das mesmas. 
Para alguns entrevistados, além de serem respeitadas, mulheres em situação de rua têm uma vida facilitada, na medida em que as mesmas despertam com maior freqüência a benemerência no Outro Distante e recebem donativos que garantem sua sobrevivência:

"As mulheres não passam tantas dificuldades como os homens, porque as mulheres ganham mais doações de roupas. Roupas de mulher são mais fáceis de encontrar, para homem a gente tem que ir à comunidade". (Hérakles, vivendo na rua, 37 anos)

Por outro lado, na fala de Ares, encontramos opinião contrária a maioria dos entrevistados: a situação dos homens na rua é facilitada, se comparada à feminina, pela capacidade física para realizar tarefas braçais e, portanto, em conseguir trabalho:

\begin{abstract}
"Eu diria que a situação dos homens é um pouco mais facilitada do que a das mulheres. Aquele que é homem pode procurar serviço braçal. Ele pode montar um local para vender alguma coisa. Essa parte braçal para carregar peso mesmo, coisa que não é tão fácil para mulher" (Ares, vivendo na rua, 27 anos).
\end{abstract}

Para Ares, o mundo da rua implica na sobrevivência como fruto do trabalho que, por exigir força física, é mais circunscrito a homens. Assim, a partir de seu olhar, o espaço da rua não oferece às mulheres tais possibilidades de trabalho em função da fragilidade feminina, cuja característica apresenta-se como central no pensamento de outros homens entrevistados. 
Destaque cabe a algumas questões consideradas pelos entrevistados como igualmente decorrentes do que entendem ser a natureza da mulher, o qual representaria ao mesmo tempo marcadores da diferença em relação aos homens e geradoras de dificuldades especificas, por exigir cuidados especiais que o mundo da rua não oferece, devido a não possuir equipamentos sociais apropriados: hábitos diários de higiene, gravidez e as implicações decorrentes de sua dupla condição, ser mulher e estar em situação de rua.

"Eu acho que é [diferente ser homem e mulher em situação de rua]. Os homens, por exemplo, você pode passar quatro dias sem tomar um banho, mas a mulher não pode. Se ela vai a um ambiente para tomar um banho ela não pode. Então tem essa diferença. Agora se tem um local para ela se encaixar, como um albergue, ai tudo bem, ela fica igual ao homem, não tem nada a ver" (Aquiles, vivendo em albergue, 49 anos).

"A única diferença da mulher seria o fato dela ficar grávida. Porque a mulher grávida teria muito mais problemas que o homem. Porque o homem quando engravida uma mulher de rua abandona e não se preocupa com este problema, este é um problema que fica ao cargo da mulher mesmo" (Ares, vivendo na rua, 27 anos).

Outro aspecto relacionado ao olhar de homens em relação às mulheres diz respeito a maior vulnerabilidade da mulher em situação de rua 
a violência e ao abuso sexual, que aparece na maioria das entrevistas como a maior dificuldade enfrentada pelas mesmas:

"Para elas é sempre mais dificil ficar nas ruas porque elas podem ser estupradas, violência sexual, agora com roubo. Agora mesmo bateram em uma empregada doméstica pensando que ela era prostituta. Então, elas sempre podem ter alguma coisa ligada a isso" (Hefesto, vivendo em albergue, 53 anos).

“... a mulher por si é mais fraca pode até sofrer abuso por parte de outros moradores que não respeitam elas ou até mesmo pessoas que sejam bem de vida e que pode agredir elas, que pode chutar por elas serem mais fracas... [Mulheres e homens têm] os mesmos problemas. A gente que mora nas ruas não sabe qual vai ser a injustiça que vai ser praticada. A gente não sabe se vai apanhar da polícia injustamente" (Hades, vivendo na rua 34 anos).

"Elas vivem na penúria. Os outros moradores de rua tentam se aproveitar delas justamente pelo fato de serem mulheres, em relação ao sexo. Muitas vezes, elas estão empregadas e são produtoras de ganhos para os mesmos... (Ares, vivendo na rua, 27 anos)".

Ao lado da maior vulnerabilidade ao abuso e à violência, as práticas sexuais femininas surgem fortemente discriminada, nas falas de homens em situação de rua, geralmente associadas à prostituição. O uso do corpo por parte das mulheres que vivem na rua é visto como um comportamento usual no contexto de vida na rua, embora em relação a ele se apresentem traços 
de um julgamento moral, como apontam relatos abaixo, de homens entrevistados pertencentes a diferentes gerações:

"Elas [as mulheres] se prostituem...Só se prostituir mesmo, não tem outra coisa que a mulher faz...Difícil! Aquelas que eu conheço é só isso mesmo. Ela está sempre pulando de galho em galho. Quando ele está duro ela vai atrás do outro que está com dinheiro e assim elas vão vivendo" (Apolo, vivendo na rua, 25 anos). "Pelo o que eu vejo umas trabalham; outras só vivem para usar drogas, se prostituírem, até mesmo roubo, então são muitos os aspectos que você vê" (Hades, vivendo na rua 34 anos).

"Têm muitas delas que são sofredoras, tem muitas que ganham, e muitas que você sabe... não é! Vivem de transa. Têm muitas que vivem nas ruas e trabalham de empregada doméstica" (Aquiles, vivendo em albergue, 49 anos).

Para Varanda (2003), a relação entre a presença da mulher no mundo da rua e a prostituição deve-se ao fato do grau de exposição das mulheres que vivem nas ruas não permitir que elas possam ora dizer sim, ora dizer não a parceiros sexuais na própria rua. Interpretação essa que aponta para as dificuldades nas negociações encontradas por mulheres, em relação a seus companheiros, no campo das práticas sexuais.

Ainda sob a ótica do julgamento moral da conduta feminina na rua, na narrativa de Hefesto, citada abaixo, o gosto pela vida noturna, a 
prostituição ou o que o entrevistado chama de "degradação", fazem com que mulheres permaneçam na rua:

"As mulheres na rua, pode ser por uma degradação, prostituição ou a facilidade de ir para as baladas, para bailes e começar a gostar, trocar o dia pela noite. Pelo menos aqui nos lugares que a gente conhece: o Centro, o Parque Dom Pedro e Pinheiros" (Hefesto, vivendo em albergue, 53 anos).

Outro traço do julgamento moral dos homens sobre as mulheres em situação de rua pode ser observado na afirmação de Hefesto, morador de albergue:

"A mulher tem que ser tratada de uma maneira diferente... Eu nunca vi uma mulher apanhando, se elas falam alguma coisa eles sempre vão querer saber. $A$ polícia e a Guarda Municipal, eles sempre pegam as mulheres mais para delatar os crimes. A mulher é mais fácil de ser levada para fazer uma denúncia, "caguetar" alguém..." (Hefesto vivendo em albergue, 53 anos).

Mais uma vez, nesse caso, manifesta-se a circularidade do pensamento masculino, de natureza essencialista em relação à mulher em situação de rua, em que podemos observar a generalização na qual elas são vistas como "informantes" da polícia e da guarda municipal, dada sua suposta facilidade em "caguetar alguém". Assim, nesse tipo de discurso, encontra-se implícita, ao que parece, a idéia de uma vitimização masculina e do uso da "natureza feminina", esta como forma de controle social de instituições sociais sobre a população de rua, caracteristicamente masculina. 
Aspecto igualmente relevante, citado em alguns depoimentos, diz respeito à "utilização de crianças" para obtenção de auxilio financeiro, fato este visto como uma estratégia feminina no contexto da rua, embora atrelada ao domínio masculino:

"...No caso assim das mulheres e tem muitas mulheres que sabe o que elas inventam agora? Elas pegam as crianças e emprestam para outro colega para ir para o sinal... É isto dá dinheiro e daí o que ela vai fazer? Ela vai dar droga para o marido e quando ela não arruma, o marido bate nela. Eu já vi muitas cenas aqui e é um problema a rua..." (Hérakles, vivendo na rua, 37 anos).

"Nós sabemos que tem muita menina nova que tem criança, fica no farol olhando e as outras ensinam. As pessoas querem adotar, muitas familias procuram moradores de rua para tentar adotar crianças, ou então pegar o filho de uma pessoa que está em risco e colocar em uma faculdade. Aqui em Pinheiros a gente tem noção disso. A gente está há dois anos aqui, então a gente tem certo conhecimento" (Hefesto, vivendo em albergue, 53 anos).

Nesse sentido, vale observar reflexões de Saffioti $(2004 ; 2005)$ que permitem demonstrar como dominação-exploração na ideologia do patriarcado andam juntos quando a exploração de mulheres por homens e de crianças por mulheres subjaz a uma dominação masculina.

Nos discursos de Hermes e Dioniso vemos situação inversa em que a luta pela sobrevivência no cotidiano da vida na rua equipara homens e 
mulheres na perda de auto-estima e na necessidade de garantir a subsistência:

"Eu acho assim: a mulher perde muito o valor e o homem também. Eu acho que não tem muita diferença... Acorda de manhã tem que tomar o café, almoça, depois tem que sair. A gente vai para batalha para arrumar alguns trocados (Hermes, vivendo na rua, 44 anos).

"É a mesma coisa, a gente sofre e elas sofrem também... É no tempo de chuva e frio, porque a gente tem que arrumar uma cobertura se não tem uma carrocinha. Porque com a carrocinha, você se cobre e coloca uns plásticos e aí dá para dormir. Agora se não tem uma cobertura nem nada, você vai tomar chuva. Mesmo com a carrocinha, os cobertores amanhecem todos molhados... Mas outro problema é a Prefeitura de São Paulo, porque eles vêm e levam tudo embora. Levam as roupas, as cobertas... ontem mesmo levaram tudo que é meu, até o meu rádio... Eu sei lá para onde eles levam e nem o que eles vão fazer com um monte de cobertores, um monte de mantimentos, comida do cachorro, marmitex da gente, que a gente ganha de doações... tem muita gente boa. Ontem levaram tudo embora, não deixaram nada" (Dioniso, vivendo de rua, 42 anos).

No depoimento de Dioniso (e nas falas de mulheres, como veremos em item que analisa a fala das mesmas), a "prefeitura" é considerada um dos maiores problemas a serem enfrentados por homens e mulheres na rua. Nosso entrevistado refere-se ao "Rapa", assim descrito por Varanda: 


\begin{abstract}
"o rapa é uma operação conduzida por coordenadores das subprefeituras, que se inicia com a pressão de comerciantes, cidadãos que solicitam a retirada de moradores de rua de um certo local [...]. São operações feitas de surpresa com um caminhão de carroceria aberta, trabalhadores da prefeitura, com o suporte da força policial [...]. ao chegarem no local, começam a recolher os pertences dos moradores de rua do local e artefatos usados para improvisar abrigos são jogados no caminhão. Podem perder roupas, remédios, principalmente se o morador de rua não estiver presente" (Varanda, 2003:73).
\end{abstract}

Ainda segundo Varanda, "este tipo de operação coloca o morador de rua [seja homem ou mulher] na situação permanentemente de infrator, na condição de perdedor e vítima ou, ainda, atesta o sobressalto pelas perdas do mínimo que se teme que é seu barraco" (Varanda, 2003: 73).

Dessa maneira, a ação do poder público, muitas vezes, antes de representar segurança, reforça por esse tipo de ação, o que Varanda (2003) denomina de uma "cultura [material] impermanente", a qual se traduz no sentimento de insegurança para homens e mulheres em situação de rua, na medida em que, nesse caso, o poder público não se apresenta como esfera de proteção aos cidadãos, mas como agente promotor da violência. 


\subsubsection{Relações sociais no mundo da rua e a transversalidade de gênero}

\section{(1) Relações sociais de gênero}

Snow e Anderson destacam que as relações entre moradores de rua

podem ser caracterizadas pela instabilidade e superficialidade explicadas, em parte, pela transitoriedade e mobilidade que caracterizam a vida na rua. Nesse contexto, para os autores, os grupos de pares representam "uma das poucas chances de validação social positiva", ao lado do apoio social e psicológico que a convivência entre iguais proporciona nesse caso. Ainda para Snow e Anderson, os grupos de moradores de rua tornam-se uma referência não estigmatizadora e uma "fonte de autovalidação interpessoal" para eles próprios (Snow e Anderson, 1998: 283-285).

Com base nas colocações desses autores, podemos considerar que moradores de rua se encontram no espaço da cidade, se "enturmam" e compartilham entre si de um sentimento de camaradagem que Ihes permite reconhecerem-se rapidamente como "companheiros". No entanto, embora "rápidos em professar a amizade na presença uns dos outros", essa amizade diverge dos padrões aceitos socialmente, na medida em que se estrutura de maneira complexa, ao oscilar entre a proximidade e a estranheza (Snow e Anderson, 1998: 290).

De uma maneira geral, pessoas em situação de rua "partilham uma certa intimidade, passando longos períodos de tempo juntos e compartilhando recursos escassos", o que pressupõe o estreitamento das relações pessoais (Snow e Anderson, 1998:291). 
Por outro lado, como pudemos observar, a convergência de trajetórias e destinos diversos que a experiência da rua, em sua fluidez proporciona, gera, pela intensidade e rapidez com que indivíduos estranhos são colocados em convivência intima, um sentimento de desconfiança mútua. Portanto, é comum identificarmos na fala dos entrevistados, episódios que refletem o paradoxo exposto.

Dentro do panorama acima, podemos entender que na complexidade das relações tecidas no mundo da rua, na cidade de São Paulo, homens representam a maioria da população, enquanto mulheres aparecem em menor escala. Dentre aquelas que pernoitam nas ruas, identificamos algumas vivendo sozinhas ou em pequenos agrupamentos de duas ou três mulheres e, em muitos casos, estas permanecem vivendo ao lado de homens, em malocas ou mesmo nas ruas.

Os relatos obtidos em nossa pesquisa apontam para a identificação de uma dinâmica própria de convivência entre homens e mulheres em situação de rua que se constitui a partir do momento em que ambos se aproximam.

O relato de Hélio esclarece alguns "códigos" que envolvem a aproximação e a aceitação das mulheres em grupos masculinos:

"Todo mundo abraça a idéia, então está chegando uma mulher nova na área e então vamos deixar ficar com a gente aqui, mas só que é aquela possibilidade e não é que ela vai ficar ali sozinha... Não, ali já tem um engraçado que já cresce o olho nela e é aí onde começa... Exatamente, e várias mulheres já fizeram coisas que eu nunca pensei em fazer... Não me interessa 
citar o nome de ninguém, mas pessoas que fazem sexo e esse tipo de coisa são complicadas. Então na rua é aquele negócio, e não é só a mulher, e tanto faz a mulher como o homem, mas se chegou a qualquer uma maloca - ôpa vou ficar naquela maloca!- chegou lá, beleza. Chegou lá, ela é bem recebida, mas pode ter certeza que gavião está de olho nela e aí é que vêm todos os problemas, e aí é quando o cara pensa que é uma coisa e é outra, então é aí que acontece. Então é por isso que muitas coisas que acontecem na rua e o pessoal pensa que é só homem que faz, não é, e pelo contrário, é muito pelo contrário. Tem mulher que tem muita experiência de vida, muita rapidez, muita velocidade e principalmente quem já passou pelo sistema penitenciário. Todos os que convivem na rua é tudo neste nivel e não adianta que são todos neste nivel, porque quando já vem de lá, já vem todo descolado. Não é que vem descolado de uma maneira de uns bons pensamentos, são só pensamentos negativos, e a pessoa que tem o pensamento negativo na mente, não tem como ele encaixar um pensamento positivo, não tem..." (Hélio, vivendo na rua, 34 anos).

Pelo discurso de Hélio, podemos identificar a figura ambígua da mulher no mundo da rua: ora é vista como um problema, ora vista como objeto de desejo para fins sexuais e utilitários. O mesmo se observa nos relatos abaixo:

"É muito simples, somente pelo fato dela ser mulher a aceitação já é maior. Normalmente entrando num grupo de homem ele já vai tomar a iniciativa de cantá-la... Normalmente, numa chamada maloca, onde tem várias pessoas, o requisito básico seria lavar roupa do marido, 
cozinhar para todos. Pedir dinheiro mesmo para o sustento do marido" (Ares, vivendo na rua, 27 anos).

"Ah! Mas aí o homem já vem com maldade e tem uns que ajuda. Tem uns que já tem outras intenções e quer ajudar, mas quer ter uma relação com ela... Vai querer alguma coisa em troca. É isto daí... se ela achar a pessoa certa, mas se não achar ela está ali e tem um prato de comida dois, três dias e vai ficar com um outro pessoal e ele também vai dizer- não vou ficar sustentando mulher à toa. Sem ter relação e estas coisas e daí fica complicado" (Hérakles, morador de rua, 37 anos).

Observamos nos depoimentos apresentados, que o sexo como moeda de troca permeia a relação entre homens e mulheres. Os papéis sociais são construídos a partir das diferenças de gênero no seguinte sentido: cabe às mulheres o papel tradicional de cuidadora do lar, calcado na tradição patriarcal, ou seja, aquela que cozinha, lava, passa e mantém o equilíbrio das relações. Como pagamento pela proteção dada à mulher, esta passa a "pertencer" sexualmente a um homem. Há, nesse caso, a perda da autonomia individual, do direito de escolha pelo ganho de permanecer viva e "protegida" da violência de estranhos e de outros homens. O que, de nenhuma maneira garante proteção contra a violência do próprio parceiro.

Ainda ressaltamos que além das tarefas domésticas, os relatos permitem observar o que homens esperam das mulheres, as quais são cobradas também como colaboradoras ou provedoras dos ganhos do companheiro, geralmente fazendo "bicos" na rua. Nas palavras de Ares: "o 
requisito básico [para ser aceita em um grupo de homens] seria lavar roupa do marido, cozinhar para todos. Pedir dinheiro mesmo para o sustento do marido“.

No processo de incorporação de mulheres em grupos predominantemente masculinos, a aceitação das mesmas parece estar sujeita a alguns critérios de inclusão e, portanto, de discriminação das mesmas, conforme relata Orfeu:

"Eu acho que a mulher na rua sofre muito mais que o homem. Se ela for jovem, logo arruma alguém para proteger ela. Mas se for de mais idade, principalmente negra, ela é excluida... É moradora de rua... é negra... e se for idosa... três niveis de exclusão... Se chegar mulher sozinha, por exemplo, é dificil se enturmar na maloca...Para ela enturmar, vai ter que ser a mãezona de todos: vai ter que cozinhar...Tudo ali vai passar por ela. Outra coisa: eles também vão querer assumir o lado marido dela para poder ficar ali sem virar bagunça. Eles não vão respeitar ela. Eu conheço mulher que acabou virando líder da maloca por causa de fazer as coisas funcionarem. Mas a maioria das vezes não é assim. Se ela chega, já tem idade, é negra... Não vai conseguir se enturmar. Se ela for atraente e chegar na maloca, todo mundo vai ser fascinado. Muitas preferem andar sozinhas porque não se enturma nos grupos. Na rua não existem grupos grandes de mulher. Apesar da hostilidade nos grupos masculinos, elas procuram os grupos masculinos...ai sofrem agressão e passam por um, por outro..." .." (Orfeu, em situação de rua no período entre 2001 e 2003, 45 anos). 
Como podemos observar, no processo de inclusão de mulheres nos grupos de convivência que se estruturam no mundo da rua, reproduzem-se valores vigentes na sociedade, nos quais dentro de parâmetros socialmente aceitos, mulheres jovens, consideradas bonitas e de pele branca parecem ser as mais valorizadas.

De fato, como trataremos no item seguinte, mulheres encontradas sozinhas nas ruas e que declararam preferir a solidão à companhia masculina pareceram-nos de acordo com o exposto por Orfeu: eram idosas, negras e, dentro da lógica proposta pelo entrevistado, não atraentes ${ }^{21}$.

Atuando, portanto, como mediadora de conflitos e organizadora da vida "doméstica", recriada na maloca ou nos grupos predominantemente masculinos, as mulheres parecem, na convivência intergrupal, representar papéis estratégicos nas disputas de poder entre homens. Supostos desentendimentos entre companheiros de maloca costumam, de acordo com o relato abaixo, serem resolvidos com a expulsão de um membro do grupo mediante uma estratégia premeditada que coloca a mulher como pivô de uma disputa, intencionalmente engendrada:

“... e tem aquele momento que não é só mulher e homem também é um arruma casa de caboclo um para o outro. Então fulano está muito folgado com a gente e vamos tirá-lo da nossa roda. É quando está todo mundo ali na muvuca. Então o que acontece? Se tem um ali que não está dando certo, então - já sei, vamos arrumar uma para ele - então dai rapidinho ele some. Ai se combina

\footnotetext{
${ }^{21}$ Quando perguntado sobre o que seria "uma mulher atraente", Orfeu elencou alguns atributos: "alta, magra, que não fosse negra".
} 
ali e dai - fulano, vamos ali comprar uma cachaça? Vamos sim, e ai aqueles que ficam aqui eles ficam preparando as mulheres e na hora que o camarada chega o outro diz - a minha mulher falou que você cantou ela, e aí, como que vai ficar? Você é louco da cabeça, rapaz! Que onda brava é esta? E aí é onde começa tudo.. Aí começa a briga.. E quando é só briga ainda é bom. Enquanto que é só bate-boca e aquilo ali resolve na paz, mas as maiores faltas dos seres humanos que ficam nesta terra e aqueles que vão para o céu ou para o lugar que Deus marcou e aqueles que convivem na rua são nestes momentos assim, e é um segundo para arrumar isto dai e é um segundo, por quê? Porque está tudo louco da cabeça" (Hélio, vivendo na rua, 34 anos).

Em outros casos é a própria mulher que parece manipular as regras da convivência entre homens ao criar situações em que o ciúme masculino aparece como motivo de disputas e rixas entre os companheiros de grupo:

"É muito simples, um sai e um dá uma saidinha - eu vou ali comprar um cigarro e já venho - todo mundo fica ali bebendo, cantando, sei lá, de repente quando o cara volta já bebeu uma pinga ou duas e ela fala para o cara fulano veio aqui e me cantou e ele só esperou você sair. Então é onde o cara nem falou nada e daí o outro vai e acredita e ele vai lá tirar satisfação com ele, mas só que ele não vai mais para conversar, não vai, ele já vai chegando e arriando o cacete e é isto que acontece na rua" (Hélio, vivendo na rua, 34 anos).

A partir dos relatos acima, podemos compreender a importância das relações de gênero na ordenação da convivência intergrupal no mundo da 
rua. No pensamento desses homens parece revelar-se uma dicotomia presente - ao menos em nível do imaginário dos mesmos - em que as "regras" do "jogo social" são delineadas, tendo como pressuposto o desempenho de papéis sociais reconhecidamente distintos, atribuídos a homens e mulheres, dentro da "lógica relacional da honra". Tal lógica, citada por Machado, quando a autora reflete sobre as masculinidades e a violência em contexto urbano brasileiro, pode ser especialmente observada entre a população de rua, na medida em que, como afirma a autora, "a honra funda a construção simbólica dos gêneros, no que eles têm de mais impensado e naturalizado". Tal construção se faz "em torno do desafio da honra, do controle das mulheres e da disputa entre homens". Assim, como conclui Machado, uma "má brincadeira que coloque em jogo a respeitabilidade da companheira implica na necessidade de uma resposta do homem desonrado àquele que o difamou" (Machado, 2004:51-52).

No cenário da rua, como nos revelam os discursos acima, um comportamento não aceitável dentro de um grupo, determina a exclusão do indivíduo que não "joga o jogo". A exclusão acontece, como pudemos observar, mediante "um teatro" em que o código relacional da honra é manipulado com a suposta cumplicidade das mulheres. A "performance" das mulheres implica uma representação, a partir de uma situação imaginária envolvendo a violação da honra masculina para que, com esse argumento, tal situação seja resolvida, muitas vezes, com o uso real da violência. 
Segundo Machado (2004), o uso da agressividade física e o poder sobre a vontade dos outros aparecem freqüentemente quando o código relacional da honra é posto à prova.

Assim, em um mundo de regras masculinas, as mulheres atuam aparentemente como supostas cúmplices dos homens, compartilhando com estes de toda a encenação, ainda que não possamos afirmar se o fazem coagidas pela imposição do grupo masculino.

No entanto, observamos no relato de Hélio que mesmo nas interações entre as próprias mulheres é comum o uso da agressividade e do poder:

\begin{abstract}
"Vamos supor, tem uma maloca com dez, doze homens e tem só duas ou três mulheres ali e de repente aparece outra, aquelas outras já ficam cabreiras, então elas falam - espera aí! Esta mulher veio de onde?- então elas já não vão conversar de uma maneira social e já vão conversar na parte da gíria, e quando entra falando gíria já é um queimando o outro e dai começa" (Hélio, morador de rua, 34 anos).
\end{abstract}

Nesse sentido, pensamos na existência de uma concepção de masculinidade no mundo da rua, ocupando um "lugar simbólico de sentido estruturante", partilhado coletivamente. Ou seja, como propõe Oliveira (2004) acerca da construção social da masculinidade na contemporaneidade, esta se constituiria em um valor social de "importância inegável em processos sociais diversos", que compreenderia "todos os objetos da vida social (agentes, leis, instituições, símbolos...)". Para o autor, a masculinidade pode "em muitos momentos das vivências dos agentes 
funcionar como uma lei que prescreve comportamentos, além de influir como catalisadora na (re)atualização de identidades, transformando-se num elemento fundamental para a subjetivação desses mesmos agentes" (Oliveira, 2004: 14-15).

O mundo da rua, neste contexto, pode ser considerado com um espaço em que a masculinidade como valor social se manifesta sob a ótica do código relacional da honra, contando ainda com a presença de drogas ilícitas e álcool, estes fundamentais na configuração da agressividade e no uso do poder, expressos pela linguagem falada, na forma de gíria.

Entretanto, a questão da masculinidade, fundamental para nosso entendimento das experiências de vida de homens e mulheres nesse cenário, ainda apresenta traços peculiares que se desvelam quando nosso olhar se dirige às relações afetivas e conjugais construídas na rua.

\section{(2) Relações conjugais, afetivas e sexuais no mundo da rua}

Quando indagados sobre as relações conjugais, afetivas e sexuais entre homens e mulheres em situação de rua, muitos homens expressaram o que denominamos de "negação do envolvimento afetivo e das relações conjugais", como exemplificam os relatos a seguir:

"A dificuldade do homem é porque o desemprego é muito grande. As mulheres, eu também acho que é o desemprego. Mas a mulher tem mais facilidade porque elas ganham as coisas facilmente. Eles dão e isso influencia muito a mulher estar nas ruas. O homem é mais atraído pela mulher, então, a mulher tem mais facilidade de conseguir as coisas na rua o que leva ao 
objetivo dela... Eu estou há quatro meses sem ter uma relação com uma mulher. Porque em situação de rua eu não tenho coragem nem de conversar, eu não tenho nem o que conversar com uma mulher. Às vezes foge da mente qualquer assunto para conversar com uma mulher. Eu tenho uma amiga que também não tem relacionamento com homem. Ela fala que não tem mais aquele prazer. Ela perdeu as coisas dela em uma enchente, perdeu tudo e não tem mais aquela vontade de sentir atração por ninguém... Só o fato de eu ter um emprego já seria diferente. Se eu tivesse um emprego com certeza eu mudaria. Hoje eu me preocupo muito em sair dessa situação e eu garanto que se eu tiver um emprego eu tenho a minha casa e pago o meu aluguel, ou até construir uma casa para mim e ter um futuro melhor. Com certeza, porque não adianta você pensar e saber que na rua aquela mulher vai conversar com você e vai querer saber onde você mora. Quando você falar que mora em um albergue você vai ser discriminado, ela não vai aceitar" (Adonis, vivendo em albergue, 23 anos.)

"Eu vou falar uma coisa para a senhora, e eu mesmo, se for para eu conviver com outro ser humano - e não é desclassificando nenhuma [mulher] - mas eu mesmo para conviver comigo eu não quero... Então se for para este tipo de mulher [em situação de rua] conviver comigo eu não quero... Por que eu não quero? Porque são mulheres que só trazem problemas... É complicado isto dai. É complicada esta situação e não é só o lado da mulher, mas é complicado tanto a mulher como o homem, e é a mesma coisa e os dois trabalham em parceria. Quando um não arruma problema o outro arruma, e se tiver os dois doidos ai é onde é o problema, porque dai como vai saber quem está certo e quem está 
errado? Não dá para saber. Então fica complicado o negócio" (Hélio, vivendo na rua, 34 anos).

"Um casal na rua não adianta nada. Você vai ficar com a mulher na rua não tem condições, porque ela precisa tomar um banho, se lavar, se trocar, o homem também. Então, como a mulher vai ficar com o marido na rua? Não tem condições" (Aquiles, vivendo em albergue, 49 anos).

"Eu nunca tive mulher na rua, mas eu, por exemplo, é o preconceito e muita gente vê você e se anda limpo e vai passando assim e está morando na área assim e eles vêem você todos os dias limpinho, tomando banho e talvez você nem esteja nem trabalhando, mas esteve em albergue e está se mantendo limpo e daí você escuta piada. Este cara rouba e não sei o que e não é por aí e por isto que eu digo que tem preconceito, porque se você anda sujo e catando latinha e estas coisas você é maloqueiro. Então fica difícil... Eles fazem muitas piadas e se a gente for ligar para isto a gente acaba endoidecendo... Tem umas que devem escutar, porque tem muitos vagabundos, "nóias", muitas que estão rua e com o homem delas e quando eles não são drogados, eles são cachaceiros. E drogado é o pior que tem e por ai vai. É um problema". (Hérakles, vivendo na rua 37 anos).

A negação do envolvimento afetivo e conjugal aparece, a princípio para os entrevistados, como uma opção que se justifica em decorrência das circunstâncias vividas pela população de rua, em um universo social caracterizado pelo uso de drogas e álcool, pelo desemprego e pela miséria. No entanto, a questão da negação do envolvimento não se esgota 
unicamente em virtude das condições objetivas de existência no mundo da rua, mas parece especialmente relacionada à concepção de masculinidade forjada na socialização desses homens.

Nascimento (1999), ao analisar a experiência de "ser homem" em um universo de homens pobres e desempregados, atenta para a existência de um padrão hegemônico vigente de masculinidade composto pelo ideal de "homem" como um ser heterossexual, dotado de poder, força, coragem e provedor do lar. Especialmente na relação entre a afirmação da masculinidade e trabalho, destacamos a pesquisa de Sarti (1996) que identifica o trabalho como condição básica para a autonomia moral no universo dos homens pobres. Para a autora, ao sentir-se destituído do trabalho, o homem deixa de corresponder às prerrogativas sociais e familiares esperadas, perdendo a moral: "Este padrão ideal pressupõe o papel masculino de prover teto e alimento, do qual se orgulham os homens". Conclui Sarti, "[...] O status central do homem na familia [e igualmente nas relações afetivas], como trabalhador e provedor, torna-o também vulnerável, porque o faz dependente das condições externas cujas determinações escapam a seu controle" (Sarti, 1996:42;46).

Assim, destituídos de emprego, muitos homens em situação de rua, sentir-se-iam, a nosso ver, destituídos também das condições que permitiriam aos mesmos sustentarem - objetiva e subjetivamente - um relacionamento conjugal e afetivo. Se tal fato pode ser observado em muitas entrevistas, em outras falas encontramos também a vivência e a percepção 
dos homens quanto aos relacionamentos conjugais, afetivos e sexuais na rua:

"Eu não posso afirmar nada sobre isso [sobre o relacionamento entre homens e mulheres na rua], porque eu nunca tive um relacionamento com mulher de rua. Pelo o que eu vejo uns vivem bem, trabalham na carroça, na reciclagem, vivem na droga um batendo no outro, um usando o outro. Vejo o homem usando a mulher para se prostituir. É esse o dia-a-dia" (Hades, vivendo na rua, 34 anos).

"As mulheres não tem muito preconceito não. Os "homens" não ligam muito para a mulher de rua não. Pode ver que mulher é mais fácil arrumar um namorado do que quando ela está em casa... Para mulher é mais fácil mesmo ela estando na rua ainda é mais fácil ela sobreviver do que o homem... Porque é mulher, para ela tudo é mais fácil" (Apolo, 25 anos, vivendo na rua).

"Não é só o homem com a mulher, porque o sistema da rua a senhora não tem uma visão assim, uma visão correta de qual é o homem sério e qual que é a mulher séria, porque ali uns respeitam a senhora e ali não tem só o homem ou a mulher, mas ali tem todo ser humano, masculino e feminino. Ali tem mulher que mora mulher com mulher, homem com homem e ai vira aquela confusão... (Hélio, vivendo na rua, 34 anos).

"Na rua é pouco tempo, vai mudando. Pode ver que uma mulher que está na rua ela fica com vários caras. Ela namora pouco tempo e vai mudando" (Apolo, vivendo na rua, 25 anos). 
"[A mulher] faz tudo por ele [o homem]. Trabalha para manter ele quando é uma mulher direita. Agora se for uma mulher vagabunda já era. Mas tem mulher sincera que chega e você é capaz de alugar um barraco em uma favela com ela que vai dar certo. Quando ela gosta de você dá certo, mas se for "nó-cega", não dá não"(Aquiles, vivendo em albergue, 49 anos).

“Já [tive mulher na rua], mas só uma noite e ai eu vi que não dava para eu ficar com ela, porque a minha vida já era difícil e vou botar uma mulher do meu lado?Se ela tivesse um lugar para ficar, um emprego para me ajudar e aí poderia até dar certo. Muitas são muito preguiçosas e querem acordar e ficar ali bebendo, ficar ali com o $c$. pregado no chão e não sai para canto nenhum. Existem aquela "parasitagem", mas tem umas que já gosta de trabalhar, são poucas, mas tem" (Hérakles, vivendo na rua 37 anos).

A diversidade de sujeitos e processos sociais que o mundo da rua encerra, permite-nos vislumbrar formas de arranjos afetivos e conjugais, conforme nos indica Hades quando relatou: "Pelo o que eu vejo uns vivem bem, trabalham na carroça, na reciclagem, [uns] vivem na droga, um batendo no outro, um usando o outro. Vejo o homem usando a mulher para se prostituir. É esse o dia-a-dia”.

Apesar de considerar relacionamentos em que homem e mulher "vivem bem" quando trabalham juntos "na carroça, na reciclagem", Hades também aponta para a violência e a exploração que estariam presentes nas relações afetivas e conjugais vividas na rua em meio às drogas. 
A mulher, nesse cenário público, segundo depreendemos dos relatos acima, é configurada como "direita" se trabalhar para manter "seu homem". No entanto, o atributo de "ser direita", por nós interpretado como confiável, na medida em que corresponde ao estereótipo da "boa moça" presente no imaginário masculino, coexiste com a generalização da mulher como aquela que "fica com vários caras", ou ainda "parasita" - aquela que espera viver às custas do companheiro.

Em casos em que o relacionamento é considerado viável pelos homens, observamos a importância que atribuem ao fato de a mulher trabalhar e contribuir financeiramente para a sobrevivência do casal. Isso nos parece ser decisivo para os relacionamentos de quem "vive bem" e sinal de companheirismo por parte da mulher.

Chama-nos a atenção que a superficialidade e a instabilidade (Snow e Anderson, 1998), caracterizadoras dos relacionamentos na rua são, nos depoimentos aqui apresentados, interpretadas do ponto de vista unicamente masculino. Em outras palavras, no discurso moral dos homens, é a mulher que "fica com vários caras", namora pouco tempo, vai mudando, e não é o homem que fica com várias mulheres. É a mulher que fica na "parasitagem", é identificada com a vagabundagem e, por isso, tornar-se-ia mais um problema entre tantos a serem enfrentados pelo homem na rua.

Nessa linha de raciocínio, outro aspecto a ser considerado no campo das relações de gênero é a vivência da sexualidade na rua: 
"A mulher quando tem o homem, ele já arruma logo uma carroça, porque a carroça é tudo. A carroça é a casa dele. Você pode fazer uma comida, pode dormir e também pode ser um motel, é tipo uma casa... Às vezes paga um hotel para passar uma noite e às vezes é aí do lado mesmo, embaixo das cobertas, que ninguém vai ver. Procura um lugar bem escondido e vai embaixo das cobertas mesmo" (Dioniso, vivendo na rua, 42 anos).

"A gente tem mais relacionamento sexual quando a gente vai a casas de massagem, ou vai a boates. Aqui em Pinheiros tem muito" (Hefesto, vivendo em albergue, 53 anos).

"Relação sexual é precário porque local não tem. Quando batalha um dinheirinho aí vai para um hotelzinho,mas não é como estar em casa" (Hermes, vivendo na rua, 44 anos).

Como pudemos observar, os locais freqüentemente utilizados para o relacionamento sexual são, além da rua ("embaixo das cobertas", como explica Dioniso), a carroça - para aqueles que a possuem -, casas de massagem, boates e, principalmente, como veremos no item seguinte, em hotéis do centro da cidade, como relata Hermes - para aqueles que ganham "um dinheirinho" - .

Para Varanda,

"a falta de recursos restringe o comportamento dos moradores de rua ao universo da rua e também o condiciona à vida segundo as regras e padrões de sociabilidade e sexualidade construídos por esta população. Quando toma banho, troca de roupa e coloca 
um dinheirinho no bolso, o indivíduo se habilita a freqüentar outros espaços, mesmo consciente das limitações que determinam o seu retorno à condição de morador de rua ou albergado" (Varanda, 2003:65).

Nessa perspectiva, a dificuldade para se ter uma relação sexual é citada por homens com parceiras "momentaneamente fixas", ou não, homens albergados ou vivendo na rua. Chama nossa atenção especialmente os relatos de homens e mulheres albergados, em que casais com filhos recorrem às mesmas estratégias que encontramos acima. A questão da sexualidade vivida nos albergues merece discussão apropriada em item posterior.

Em comparação à sexualidade vivida entre quatro paredes, Ares garante que na rua, sexo e carinho são experimentados da mesma forma. O que muda, segundo ele, é a visibilidade que o espaço público impõe as pessoas em situação de rua, tornando homens mais violentos:

\footnotetext{
"O sexo é normal, o carinho é a mesma coisa. A diferença, eu diria, é que como a maioria que estão nas ruas e se não gostam, eles seriam mais violentos que um homem normal... Porque numa casa com a preocupação do social, de vizinhos mesmo que houvesse todas essas brigas eles não iriam aparentar. Eles iriam minimizar este comportamento violento. Todas [as mulheres] que eu conheço estão em grupos que têm homens ou com maridos, a mulher que tem um companheiro fixo. Eu nunca vi um grupo só de mulher" (Ares, vivendo na rua, 27 anos).
} 
Na lógica de Ares, a rua seria o espaço em que o homem não encontraria os constrangimentos impostos pelos códigos de valores que regem o convívio regular entre indivíduos e, sem a proteção das paredes da casa, estaria livre da "preocupação social" para assim manifestar seu comportamento violento, sem testemunhas conhecidas ou acusações que afetassem sua reputação.

Segundo Fonseca, em seu estudo sobre camadas populares, no convívio com os grupos de vizinhança, seria de "capital importância" gozar de uma boa reputação, na medida em que "o prestígio de um homem depende do conhecimento público de sua coragem, de sua virilidade e de sua generosidade" (Fonseca, 2000:42-43).

Com base na afirmação da autora, podemos compreender que o temor de uma má reputação existe na proporção das relações de vizinhança ou convivência cotidiana entre moradores ou trabalhadores de um mesmo local, nos quais as informações, fatos e fofocas circulam entre familiares e/ou "conhecidos".

Portanto, a rua com suas relações fluidas e superficiais, tornar-se-ia o palco privilegiado para o exercício do poder desmedido de homens sobre mulheres, na medida em que estes estariam desprovidos do controle social de "conhecidos", no sentido de reificar ou não uma reputação.

\section{(3) O lugar da mulher no cenário do mundo da rua}

Neste item, buscamos entender como se dá a apropriação do tempo cotidiano pelas mulheres, na ótica masculina. Ao mesmo tempo, 
pretendemos conhecer como se opera a divisão de tarefas entre homens e mulheres no contexto da rua:

"[Mulheres na rua estão] A pedir, lavar roupas, queimar latas, tem carroceiros que leva a mulher na carroça ou a deixa trabalhando. Normalmente em qualquer lugar que tem uma mulher e uma criança é mais difícil a polícia pegar e tirar..." (Hefesto, vivendo em albergue, 53 anos).

"Elas ficam nos faróis limpando vidros de carro, outras estão na praça pedindo. Na verdade, sempre existe um homem por trás das mulheres que estão na rua. Geralmente, quando a mulher está em situação de rua sempre aparece alguém, um homem mesmo, para querer tirar proveito disso. Hoje você encontra aqui no largo de Pinheiros várias mulheres vendendo balas, até meninas novas de 14 ou 15 anos estão vendendo balas, enquanto têm marmanjos que estão bebendo cachaça na praça" (Adonis, vivendo em albergue, 23 anos).

Nos depoimentos acima, a mulher na rua executa as tarefas do "lar" (atribuição tida como feminina observada em outros depoimentos, como veremos no decorrer desta pesquisa), ao mesmo tempo em que esta atua na esfera do trabalho, fora dos domínios "domésticos".

Villela e Barbosa (1996), em artigo no qual repensam as relações entre gênero e sexualidade, atentam para o seguinte fato: "a mulher faz trabalhos de homens, embora os homens não façam trabalhos de mulher, o que é entendido de acordo com a função das respectivas naturezas". Assim, de acordo com as autoras, a natureza de ambos acaba por excluir os 
homens do acesso às tarefas da vida privada, mais do que exclui as mulheres da vida pública (Villela e Barbosa, 1996:192-193).

Dessa maneira, a divisão do trabalho no mundo da rua entre homens e mulheres, parece se assemelhar ao universo analisado por Villela e Barbosa (1996), ampliada, no entanto, pelo fato de que a atuação da mulher nesse contexto parece se dar sob o domínio masculino. Em outras palavras, o trabalho realizado pela mulher consistiria, como já nos referimos anteriormente, em bicos - guardar carros, limpar vidro de carros - e na mendicância - tarefa essa considerada "trabalho" -, como abordaremos no item 4.4. Em ambos os casos, a exploração da mulher pelo homem é explicitada na fala dos próprios homens, como já nos relatou Adonis:

"Hoje você encontra aqui no largo de Pinheiros várias mulheres vendendo balas, até meninas novas de 14 ou 15 anos estão vendendo balas, enquanto têm marmanjos que estão bebendo cachaça na praça" (Adonis, vivendo em albergue, 23 anos).

Ao que nos parece, independente da existência material de uma casa, condição objetiva a partir da qual é possivel reconhecer a existência das dimensões pública e privada, a vida para homens e mulheres em situação de rua opera com a mesma distinção, sendo que a separação entre o público e o privado acontece subjetivamente. Em termos práticos, a dimensão doméstica/privada parece ser (re)significada de maneira subjetiva e expressa na execução das tarefas femininas no mundo da rua, como lavar, passar e cozinhar nos agrupamentos na calçada e nas malocas. Enquanto 
isso, no âmbito da esfera pública, a mulher atua dentro de uma concepção que considera a mendicância e os bicos como trabalho "fora de casa". Nesse modo de vida, o trabalho na rua para as mulheres se nos apresenta menos como uma forma de conquista de autonomia e mais como uma das modalidades de violência a que as mesmas são submetidas.

Vale ressaltar mais uma vez, no que diz respeito à convivência entre homens e mulheres, a ausência de falas que identifiquem a mulher, no quadro das transformações e conquistas femininas nas últimas décadas. A rua surge, portanto, analisando o olhar masculino, como um espaço em que o exercício do poder masculino sobre o feminino encontra fundamento na concepção de "homem de verdade" presente no imaginário do homem brasileiro. Nolasco (1997) atenta para o ideal masculino ancorado na tradição patriarcal brasileira - e, portanto, presente na socialização de homens e mulheres desde a infância - em que ser "homem de verdade" significa a negação de quaisquer possibilidades de fracasso.

Nessa linha de raciocínio, a rua pode ser interpretada como o local dos fracassados, dos caídos (Vieira, 2004), dos náufragos (Declerk, 2001) e, portanto, a construção da masculinidade encontra aí um espaço de atuação em que mais do que em qualquer outro local, os homens enfrentam face a face todas as possibilidades de fracasso e limitação.

Dessa maneira, podemos pensar o comportamento violento dos homens, em relação às mulheres - e não somente em relação a elas -, segundo a linguagem proposta por Nolasco (1997:27), como uma "tentativa precária de diferenciar-se do outro", ou seja, de afirmar-se perante os pares 
e a própria sociedade em um cenário de invisibilidade e exclusão, onde relações de gênero adquirem especificidades.

Podemos ainda considerar como hipótese explicativa que no mundo da rua este tipo de comportamento, que mescla sexo e violência, exacerbase porque aparece permeado pelo uso de drogas e álcool. Além disso, ao homem despojado de praticamente todas as possibilidades de se identificar com o que socialmente se entende como um "homem de verdade", no imaginário da ideologia patriarcal resta a alternativa do uso da violência como forma de afirmação da virilidade (Nolasco, 1997) e para o resgate da honra (Machado, 2004). Daí a significativa afirmação de Saffioti de que "o próprio gênero acaba por se revelar uma camisa de força: o homem deve agredir, porque macho deve dominar a qualquer custo e mulher deve suportar agressões de toda ordem, porque seu destino assim determina" (Saffioti, 1999:88)

\subsubsection{Da rua para a casa: um retorno possível?}

Em muitos relatos de homens em situação de rua, como vimos no inicio deste item, encontramos uma tendência a ver a ida da mulher para a rua como uma opção da mesma frente a problemas pessoais. Se assim o é, como estes homens pensam ser possível a saída da mulher do mundo da rua?

"O futuro da mulher para sair da rua é só se ela achar um camarada bom, trabalhador, pode ser até ladrão. Se ele gostar dela e ela gostar dele é bom ela sair da rua. 
Pode morar até em baixo de uma ponte, é só os dois ficarem tranqüilos que acabou. Ou alugam um barraco e saem da rua, os dois se gostando não têm diferença do homem para a mulher (Aquiles, vivendo em albergue, 49 anos)

"Se a mulher não arrumar um emprego ou um marido, fica difícil. Porque mulher não quer saber de nada... só droga... na rua é só droga..." (Apolo, vivendo na rua, 25 anos).

"Em primeiro lugar eu acho que para as mulheres saírem da rua não tem como. A rua trás muita regalia. Muitas delas estão ganhando dinheiro para sustentar o seu vicio Muitas acham que a rua é diversão... Eu acho que não tem como tirar esse pessoal que vive na rua, a não ser que o povo parasse de dar esmola. Se ninguém desse nada a ninguém" (Adonis, vivendo em albergue, 23 anos)

Dentro do discurso masculino de caráter essencialista, discriminatório e permeado de julgamento moral que caracterizou os depoimentos deste item, os homens acreditam em dois caminhos possíveis para a mulher deixar a rua: encontrar um emprego ou, sobretudo, arrumar um marido - um "camarada bom, trabalhador [que] pode ser até ladrão", de acordo com Aquiles.

Por outro lado, Adonis exterioriza seu "pessimismo" quando não acredita ser possível a mulher deixar a rua, salientando o papel fundamental que a benemerência ocasional tem na manutenção da condição de rua. $\mathrm{Na}$ fala de Adonis, encontramos a crítica já presente em Varanda (2003) a este tipo de assistencialismo: "As ajudas materiais isoladas não tem muitas 
chances de sucesso quanto à transformação da vida dessas pessoas, quando se trata de casos crônicos ou de pessoas mais experientes nas ruas". No entanto, conclui Varanda, "independente da motivação das relações de ajuda com o morador de rua ser assistencial, caritativa, solidária ou ética, resta saber se tais relações resultam na minimização, na manutenção [como propôs Adonis] ou na ampliação das vulnerabilidades individuais e como isto acontece (Varanda, 2003:86;92).

\section{$4.4 \mathrm{O}$ olhar das mulheres em situação de rua sobre si mesmas}

\subsubsection{Da casa para rua}

Inúmeros autores, como Nasser (2001), têm enfatizado tanto a saída de casa para o mundo da rua, como a permanência nas ruas decorrentes de condições macro-estruturais advindas dos processos de globalização e de exclusão social, tais como desemprego, carência de moradia, entre outros aspectos. A despeito de tal relevância, especialmente observada em pesquisas sobre homens em situação de rua, a ida para a rua raramente representa um evento isolado ou monocausal, mas, ao contrário, sobretudo no caso de mulheres, sugere que a predisposição para que estas "entrem" e/ou permaneçam no mundo da rua não se explica unicamente, em muitos casos, pela via macro estrutural.

Para as mulheres investigadas, um aspecto relevante que sinaliza a ruptura com o "mundo" da casa são processos micro-estruturais relacionados à dinâmica familiar que se apresentam de maneira expressiva 
através do relato de experiências de instabilidade familiar, sobretudo violência doméstica, alcoolismo e perdas afetivas.

Nesse sentido, o lugar de destaque da instituição familiar aparece como dado significativo, esta associada às motivações para sair de casa e buscar a vida nas ruas. Podemos considerar como motivações situações de instabilidade familiar e experiências traumáticas, por exemplo, a perda de membro da família (mãe, pai, marido/companheiro), implicando dificuldades de sobrevivência, perda de identidade familiar, ausência de rede de apoio familiar, assim como busca de rupturas com o grupo de origem por diferentes motivos.

"Estou na rua, desde 97, quando o meu marido morreu. Eu fui levar almoço para ele e ele morreu de repente. Eu fui levar almoço para ele no serviço e quando eu cheguei, ele já estava morto, aí eu entrei em estado de choque. Eu tinha um barraco em uma favela. Aí eu entrei em estado de choque e hoje, depois de dez anos, eu procuro dentro do meu cérebro como foi o enterro do meu marido e eu não acho. Me deu um branco e bloqueou. E bloqueou a parte sexual também" (Selene, vivendo em albergue, 55 anos).

De acordo com Jones, apesar da diversidade de experiências de vida que pessoas em situação de rua relatam para chegar a essa condição, é possível, no caso de mulheres, perceber trajetórias semelhantes em que a dependência de outros para obter acomodação e a instabilidade quanto a um local fixo para residência são elementos fundamentais para o processo de desvinculação do núcleo familiar (Jones, 1999:10). 
Soma-se ao exposto, relatos de problemas ligados à violência doméstica entre pais (padrastos/madrastas) e filhos, assim como entre casais, que culminaram na trajetória da mulher em direção à rua. Para Geofrey e Brown (2001), conflitos familiares são o principal motivo que leva jovens à vida nas ruas. Muitas entrevistas revelaram a díade alcoolismo e violência simbólica, como nos relatam Dóris e Ariadne:

"Eu morava com a minha mãe, com o meu padrasto e meu irmão. Só que eu nunca me dei com o meu padrasto, porque ele é alcoólatra, é agressivo. Eu agüentei muitas humilhações dele Eu estava desempregada e ele jogava na minha cara que eu não trabalhava. Eu acabei não agüentando mais e sai de casa. Passei uns tempos na casa de uma cunhada minha. Procurei uma assistente social e pedi que ela me ajudasse arrumar algum albergue. Ela conhecia alguns albergues e ela escolheu um que melhor me encaixasse, para mim e para a minha filha" (Dóris, vivendo em albergue, 20 anos).

"Na casa do meu pai eu conheci o pai da minha filha, fui morar com ele e ele começou a me maltratar também, e quando eu engravidei dela, ele falou que era para eu abortar que ele não queria saber. Então fui embora e voltei para a rua de novo. Quando eu voltei para rua não consegui agüentar ficar grávida com ela e cheguei a comer até milho cru e passava mal e por pouco não perdi ela, pois até sangue eu cheguei a perder, mas graças a Deus eu consegui segurar ela. Depois que eu tive ela, pelo menos a minha vida mudou bastante" (Ariadne, vivendo em albergue, 25 anos). 
A instabilidade das relações familiares associada às precárias condições de vida das camadas populares parece indicar que o grau de vulnerabilidade das pessoas pertencentes a essa camada social é maior no sentido de sua inserção no mundo da rua, sobretudo quando não existe a identificação com uma rede familiar de apoio muito característica nesse meio social (Fonseca, 2000; 2005).

Outro aspecto que relaciona a instabilidade familiar com a ida para a rua é a tríade prisão de familiar, alcoolismo e violência doméstica:

"Em casa, eu era a mãe e o pai dos meus filhos. O meu marido nunca me ajudou em nada, com nada, e daí eu comecei a trabalhar e meu filho infelizmente começou a praticar contravenção, e tal, e foi preso. Então ele foi preso e inclusive ele está agora no albergue há 15 anos e entrou no latrocínio e foi aí que começou a desavença na família. Então daí eu e meu marido nos separamos e ele está em Guaratinguetá e a casa que tem lá é nossa, minha e dele, aliás, está no nosso nome porque quem mora lá é o meu filho. Então foi ai que começou a desavença na familia e daí eu comecei a beber e ele também, separamos e eu estou na rua. Então eu fico aqui no farol para ganhar um dinheirinho para eu comer e comprar o meu cigarro" (Éris, vivendo na rua, 50 anos).

Segundo Wardhaugh (1999), o aparente paradoxo da saída do mundo da casa para o mundo da rua e sua relação com a instabilidade familiar experimentada por muitas mulheres em situação de rua, pode ser explicado, em parte, por estas "sentirem-se sem casa dentro da própria casa", ou seja, quando mulheres concebem o ambiente doméstico como 
"uma prisão". Em casos com esse, conclui a autora, "literalmente a situação de rua, embora traga privação material e perda de referências identitárias [dadas pelo pertencimento à família de origem], representa, por outro lado, a liberdade [da opressão a que estavam sujeitas]" e a possibilidade de "encontrar seu lugar no mundo" (Wardhaugh, 1999:106).

Ainda dentro das questões que envolvem o relacionamento com a familia, a dependência de drogas também emergiu como "evento significativo" de desfiliação familiar:

"Eu já estava com uma série de problemas. Eu sempre trabalhei e morava sozinha anteriormente, e nos últimos onze meses eu tive problemas porque entrei nas drogas, então perdi emprego, perdi moradia e não tinha a quem recorrer, porque eu já era responsável por mim mesma. Eu me encontrava muito angustiada e lá eu não tinha mais recurso. Para não dever na rua lá, porque eu tinha muitos conhecidos, muitos amigos e não queria que ninguém me encontrasse em situação difícil, eu resolvi vir [embora para o sudeste do país]" (Afrodite, vivendo em albergue, 24 anos).

De acordo com Alvarez (1999;2003), sucessivos períodos de desestabilização nas relações familiares, associado à falta de um "ponto de apoio" individual (simbólico ou concreto - outra pessoa) ou coletivo (como a família, por exemplo), entendido como o "outro significativo", apontam para o momento de ruptura e trajetória para a rua.

Além de questões microestruturais, aspectos macroestruturais relativos às precárias condições de vida da população estudada, 
especialmente referidas à perda de emprego e dificuldade de reinserção no mercado de trabalho, surgiram nos relatos, ainda que minoritariamente, como razões as quais motivaram ou levaram mulheres para o mundo da rua:

"Eu arrumei emprego, sai da rua e depois perdi o emprego, porque não deu certo. Eu não consigo pagar aluguel, então eu tenho que voltar para a rua" (Perséfone, vivendo na rua, 50 anos).

"Eu tinha a minha casa na Avenida São João. Eu não tive mais dinheiro para pagar o aluguel" (Ártemis, vivendo na rua, 42 anos).

Um último aspecto a ser considerado para a compreensão das "razões" que levam mulheres a viverem nas ruas diz respeito à ênfase dada as enfermidades mentais nas pesquisas em saúde como, por exemplo, a de Robertson (1991). No entanto, em apenas uma entrevista pudemos identificar o relato de sofrimento psíquico.

"Eu tive um surto de esquizofrenia e eu achava que eles (a familia) estavam contra mim e simplesmente sai de casa, fui morar na rua...Eu fui estuprada. Roubaram todo o meu dinheiro, roubaram todas as minhas roupas. Depois foi um rapaz quem me achou, um antigo namorado... Eu fui da Igreja da Consolação até o Jaguaré a pé. Eu tinha carteira, tinha carteira de acompanhante, mas eu achava que o pessoal estava contra mim e que eles não queriam que eu entrasse no ônibus, então fui a pé. Eu ia passando nos bairros e ia dormindo" (Diana, vivendo em albergue, 38 anos). 
Casos como o de Diana são comuns na literatura que relaciona o sofrimento psíquico com o fenômeno do viver na rua. Nesse contexto, a maioria dos autores que se dedica a essa temática, considera que muitos sinais, episódios ou sintomas indicativos de sofrimento psíquico podem ser identificados previamente na história de vida da pessoa em situação de rua com sintomas de sofrimento mental. A idéia presente nesses estudos, a ida para a rua, em situações como a exposta por Diana, seria decorrente de problemas psíquicos já manifestados, que causariam diretamente a perda da moradia fixa. Na opinião de Dean e Craig (1999), um aspecto fundamental que liga o sofrimento psíquico ao fenômeno de viver na rua é que esse tipo de psicopatologia interfere diretamente na capacidade de manter relações pessoais e, portanto, afeta igualmente a habilidade para se conseguir um emprego. Nesse contexto, famílias de pessoas em sofrimento psíquico encontram dificuldade para dar-Ihes o suporte emocional e financeiro, necessários ao tratamento das mesmas. Esses autores defendem a idéia de que a experiência do viver na rua seria uma condição agravante do processo por considerarem que nas condições de vida na rua: "o stress associado a morar na rua pode exacerbar um problema de saúde mental, tornando ainda mais difícil que a pessoa envolvida encontre uma moradia estável [que podemos entender como uma forma de saída do mundo da rua] no futuro" (Dean e Craig, 1999:1).

Para Liebow (1993), a questão das "enfermidades mentais" em mulheres em situação de rua, além das alcoólatras e dependentes químicas são rótulos e generalizações que devem ser enfrentados empiricamente, 
dada a complexidade do fenômeno. Daí, de acordo com o autor, a dificuldade de diagnóstico desse tipo de problema de saúde, particularmente em mulheres, uma vez que as mesmas vão para as ruas por motivos diversos, embora muitas delas acabem mentalmente doentes por estarem nas ruas. Em outros casos, quando mulheres poderiam ser consideradas potencialmente recuperáveis, estas, pelas circunstâncias de vida no mundo da rua, não teriam condições ou teriam dificuldades para se reconstruírem psiquicamente e mesmo receberem assistência à saúde de maneira adequada.

Embora o relato de Diana nos aproxime das interpretações de Dean e Craig, consideramos que a questão da saúde mental das mulheres em situação de rua sugere, como propõe Liebow, a importância e a necessidade de estudos específicos no campo da saúde pública, que contemplem as contribuições das ciências da saúde e das ciências sociais, capazes de considerar a complexidade das relações entre o morar na rua e a saúde mental.

\subsubsection{Ser homem e ser mulher em situação de rua}

Quando indagadas sobre o que teriam a dizer sobre a experiência de viver na rua para homens e mulheres, ou seja, se haveria especificidades ligadas a condição feminina que caracterizaria experiências diferenciadas do viver na rua para ambos, as entrevistadas revelaram, de uma maneira geral, que homens e mulheres compartilham, de maneira igual, do sofrimento a que estão expostos. 
Ao serem perquiridas sobre a existência, ou não, de situações que mulheres enfrentam nas ruas diferentemente de homens, muitas das entrevistadas relataram que ao viverem na rua, as mesmas se deparam com o que podemos chamar de "questões do corpo", apontadas como especificidades ligadas à condição feminina, tais como: menstruação, gravidez, amamentação e necessidade de higiene - esta tida como "uma necessidade tipicamente feminina"-.

"A única diferença é que a mulher menstrua. Quando ela está grávida ela tem dificuldade, quando ela está com criança, ela têm que amamentar. Essas são as maiores dificuldades, os maiores sofrimentos. Mas nos outros aspectos, os homens e as mulheres sofrem a mesma coisa; o frio, a fome, a agressão de serem mortos à paulada e queimados" (Hécate, vivendo na rua,42 anos).

"Tem muita dificuldade. Principalmente para tomar banho, usar o banheiro. O homem em qualquer parede "mija", a mulher não, ela tem que se abaixar. Durante o dia eu ia aos bares, mas a noite não tem onde, era muito difícil... Eu acho que tudo é difícil para a mulher. O homem se enfia em qualquer buraco, a mulher não. $A$ mulher é mais frágil, mais delicada. A mulher na rua sofre mais do que o homem" (Héstia, vivendo em albergue, 37 anos).

"Na rua tem muitos homens e menos mulheres. O homem na rua ele bebe demais, ele usa muita droga. Eles levantam de manhã e não querem café, não querem comida, a primeira coisa que ele vai procurar é cachaça. Tem mulheres que são assim também, mas eu acho que a mulher é mais responsável com a saúde que o homem. 
O homem é mais deturpado" (Selene, vivendo em albergue, 55 anos).

Podemos observar que, a partir da visão de mundo das entrevistadas, as questões do corpo aparecem como marcadores da diferença ente homens e mulheres. Dessa maneira, as percepções sobre ser homem e ser mulher em situação de rua parecem calcadas na natureza irremediável do sujeito: fragilidade, delicadeza, responsabilidade são atributos considerados essencialmente femininos e, em contrapartida, homens seriam naturalmente pouco responsáveis com a saúde, "deturpados" e, por dedução, mais fortes e menos delicados.

Outro aspecto relevante na fala das mulheres em situação de rua, reveladora dos conflitos de gênero que parecem expressar, é o sentimento de vulnerabilidade ao abuso sexual e à violência, dados pela condição física feminina dominada pela força masculina. Episódios traumatizantes relacionados à violência sofrida pela mulher em situação de rua ocupam lugar de destaque, como no relato abaixo:

"Eu fui estuprada por cinco caras. Eu vi a minha morte. Eles pegaram eu e a minha amiga, eles quase nos mataram. Eu olhei para o céu e pedi para Deus me ajudar. Eu fiquei tão perturbada que eu comecei a ouvir gente andando atrás de mim, ouvir vozes, eu não podia ver um homem na minha frente que eu gritava. Agora eu fiz um tratamento e estou melhor" (Eurídice, vivendo na rua, 39 anos).

Além da violência consubstanciada materialmente, a violência potencialmente considerada se fez presente em muitos relatos: 


\begin{abstract}
"Para a mulher significa uma situação de risco maior, porque você está sujeita a um estupro, sujeita à prostituição. Você não tem um lugar para fazer a sua higiene, e a mulher tem que se tratar de uma maneira mais cuidadosa. Então é bem mais difícil neste aspecto. É por isso que passei por vários locais, porque eu não tinha coragem de dormir embaixo de um viaduto. Pode chegar um homem bêbado, drogado e cometer um ato destes (Afrodite, vivendo em albergue, 24 anos).
\end{abstract}

A rua, como um espaço de risco para a mulher encontra-se presente no imaginário de nossa cultura, como aponta o estudo de Martinez e col. em que a associação entre espaço público e espaço perigoso é, especialmente no caso das mulheres, resultado de um processo de aprendizagem que começa com o controle e contínuas advertências dos pais, os quais consideram, de maneira geral, que suas filhas são vulneráveis aos perigos do espaço público. No processo de socialização da mulher, portanto, haveria o constante reforço dessa vulnerabilidade pela família, amigos e, em última análise, até mesmo pelos meios de comunicação. De acordo com as autoras, a partir das orientações recebidas, as mulheres tendem a "restringir seus movimentos a lugares freqüentados ou conhecidos e a certas horas do dia, ou mesmo buscam a companhia de um homem que as proteja da agressão de outros homens" (Martinez e col., 1995: 299). Esse tipo de interpretação pode ser exemplificado pela fala de Éris, a seguir:

"O homem na rua tem diferença e a mulher não. $A$ mulher tẹm que se esconder em algum lugar e se aparar 
em algum amigo. O homem vem e quer se aproveitar da mulher. Comigo nunca aconteceu isto, porque eu tenho meus amigos aqui na rua. (os amigos) Me protegem, os meus me protegem. Não sei das outras, mas os meus me respeitam, me protegem. A mulher, se ficar sozinha na rua, os homens vêm e se aproveitam da mulher" (Éris, vivendo na rua, 50 anos)

Novac e col.(1996), em pesquisa sobre mulheres em situação de rua no Canadá, salientaram que mulheres nessa condição tendem, mais que os homens, a mencionar a necessidade de proteção como uma questão fundamental, em decorrência das características inerentes ao viver na rua, passivel de serem entendidas como a falta de segurança para dormir, a "fragilidade" feminina - presente em um grande número de relatos - frente a situações de risco extremo, em que a força física masculina representaria a solução para muitos conflitos.

No discurso das mulheres vivendo nas ruas, é freqüente, nas pesquisas dessas autoras, a referência à necessidade de encontrar "um amigo" como garantia de que ao tê-lo por perto, os riscos de abuso e violência são minimizados, aspecto que igualmente observamos nos relatos de algumas mulheres, como o de Éris, acima citado.

Novac e col. afirmam que há uma espécie de acordo que se constitui da troca de segurança - esta fornecida pelo homem - pela perda da autonomia feminina, o que entendemos se aplica igualmente ao caso 
brasileiro. As autoras, ao citar Toth ${ }^{22}$ ainda consideraram que essa questão se apresenta de maneira paradoxal, na medida em que a busca de um protetor é, muitas vezes, a opção mais recorrente nos depoimentos do que a procura por instituições e programas governamentais (Novac e col., 1996:23).

Se a rua representa o espaço em que a vulnerabilidade feminina se acentua e se diferencia da masculina, em termos da desigualdade e violência de gênero, uma vez que o mundo da rua pode ser considerado como tipicamente masculino, vale observar, no entanto, que o mesmo se configura como um espaço de discriminação tanto para homens quanto para mulheres, quando se indaga das mesmas a percepção que possuem de como são vistas pelo Outro Distante - os não moradores de rua entrevistados -, conforme exemplificam os vários relatos, a seguir “...Eles (os transeuntes) jogam muita coisa, cacos de garrafas... embaixo do viaduto que eu estava. Eu gostava de ficar lá, porque era mais tranqüilo, mas agora não dá mais... Jogam de propósito mesmo. Eu fico sozinha, eu não gosto de chamar ninguém para ficar comigo, porque sempre dá confusão. A primeira noite é sempre mais difícil, mas depois a gente acostuma" (Perséfone, vivendo na rua, 50 anos).

"O Rapa. Eles batem na gente e levam as nossas coisas... Amanhã mesmo eles vêm na parte da manhã... Hoje eles passaram e já avisaram: amanhã eu estou aí, viu? E aí a gente tem que correr para eles não baterem na gente... Eu converso com eles, porque eu não falo

${ }^{22}$ TOTH, J. (1993) - The Mole People: Life in the Tunnels Beneath New York City. Chicago: Chicago Review Press. 
mal; não gosto de brigar. Aí eles dão as minhas roupas e tudo... Isso aqui eles tinham pegado [mostra uma espécie de edredom com a qual está coberta]. Mas aí ele me deu de volta e me deu até outro cobertor (Ártemis, vivendo na rua, 42 anos).

"Muitas pessoas nem na cara da gente olhavam. As pessoas tratam a gente com muito desprezo. É como você ver um cachorro sem dono e não estar nem aí. Mas muita gente parava e perguntava o porquê a gente estava naquelas condições" (Héstia, vivendo em albergue, 37 anos).

"Você vai pedir comida no bar, - Me dá um pouco de comida que eu estou com fome. - Não tem. Aí eles preferem jogar fora do que dar para os outros... Não falam nada. Viram as costas e saem andando... Às vezes eu peço dinheiro e me mandam procurar serviço e eu falo que esse é o meu trabalho" (Koré, vivendo na rua, 31 anos).

"Tem uns que dão risadas, chamam de velha, mas têm outros que são legais. Eu conheço bastante gente que eu comprimento e bato-papo" (Perséfone, vivendo na rua, 50 anos).

"Uns passam e tem nojo, outros passam e olham com aqueles olhos de..., outros passam e ficam com dó e são várias as pessoas" (Éris, vivendo na rua, 50 anos).

"Essas pessoas mais sofisticadas, essas madames. No lugar onde a gente vai almoçar tem uma fila e a gente fica esperando abrir, quando elas passam elas falam: "esses indigentes, esses sem teto". Elas falam que a 
gente está colocando doença na cidade...[...]. A rua não presta, tem muita coisa ruim, tem muita gente boa na rua, mas tem gente má também" (Eurídice, vivendo na rua, 39 anos).

"As pessoas que eu conheci no albergue de O. eu via que tinham um preconceito, que as outras pessoas que estavam passando nas ruas elas tinham uma postura diferente. Tinha a postura de nojo. "Ela está assim porque quer. Está assim porque é um bêbado, eu não vou dar nada e não quero nem saber! Teve um momento que eu fui para igreja com um rapaz que estava no albergue de $\mathrm{O}$. comigo, ele estava me acompanhando, eu contei para ele a minha experiência e realmente eu notei que ele queria se reabilitar, tanto que ele arrumou emprego antes do que eu, e agora ele está trabalhando, está tentando levar uma vida normal. Um dia que eu fui sem ele para a igreja onde a gente sempre pedia alguma coisa para comer, uma pessoa da igreja chegou para mim e falou: _ "Olha, por que você não vem para a igreja sozinha?" Eu perguntei: "Por quê?" - "Porque você anda com esse tipo de gente e dá a impressão que você é igual". Naquele momento aquilo para mim doeu, porque eu vi que era igual. Eu respondi para essa pessoa: "Mas eu sou igual. Eu não tenho para onde ir. Eu não tenho dinheiro e estou assim pelos mesmos motivos dessa pessoa." Eu percebi que não é bom, que não é fácil. Eu percebi que eles não vêem com bons olhos como eu também não vi um dia. Tinha, em termos. Porque quando eu trabalhava e estudava e passava por algum lugar e via alguém na rua, eu sempre me perguntava: por que aquela pessoa estava ali? Eu imaginava: será que algum dia essa pessoa teve um lar? Será que ela teve um emprego? Será que essa pessoa 
quando atingiu a idade de andar e falar jogaram na rua e ela está assim? Eu sempre me fazia essas perguntas. Então eu percebi que da mesma forma que aconteceu comigo acontece com as outras... Então eu ficava me perguntando - era uma curiosidade também que eu tinha, não é? Eu fazia todo aquele cenário: "Nossa, essa pessoa nunca teve uma casa? Como ela dorme embaixo de um viaduto ou no frio ou na chuva? Como consegue passar tantos dias sem tomar um banho? Então é uma coisa muito complexa..." (Afrodite, vivendo em albergue, 24 anos"

Das múltiplas possibilidades de leitura que os relatos acima permitem, identificamos o preconceito, discriminação, desrespeito, repúdio (nojo e desprezo) e desconhecimento dos dramas existenciais que caracterizam a vida de quem está na rua como principais aspectos citados pelas entrevistadas, quando estas expressaram sua percepção sobre como são vistas pelo Outro Distante. A todas essas identificações acima mencionadas, especialmente a relacionada à suposta indiferença do Outro Distante, soma-se o caráter blasé, descrito por Simmel (2005) e por nós caracterizado no item referente ao olhar do Outro Distante.

Se as considerações acima permitem demonstrar a complexidade do que é ser mulher em situação de rua, esta se acentua quando se refere a ser simultaneamente mulher, gestante e mãe em situação de rua. Nesse aspecto, a maternidade tem sido citada por homens e mulheres como um dos grandes diferenciais da inscrição da mulher em relação ao homem no mundo da rua. 
No relato das mulheres vivendo em situação de rua, os filhos representaram o desafio da maternagem a céu aberto. Para aquelas mulheres que permanecem nas ruas, as estratégias de sobrevivência engendradas para criar os filhos nos revelam que o papel de mãe cuidadora se sobrepõe ao de mulher em situação de rua, como podemos observar no relato de Héstia:

"Quando eu estava na rua, estava calor sabe o que eu fazia? Eu colocava duas garrafas de refrigerante cheias de água no sol para poder dar banho nela, ela tomava banho ao vivo, para todo mundo ver, o povo estava passando e eu dando banho na minha filha. A roupa eu lavava nos chafariz, para dormir eu jogava o papelão no chão e colocava o edredom em cima e dormia, nem colchão eu não tinha. Então as pessoas têm tudo e não dá valor aquilo que tem...Raramente a gente tinha almoço e janta. Eu conseguia só o almoço, porque o restaurante fecha cedo. Eu agradeço muito a um restaurante que tem ali no Paissandu, porque ele me dava comida todos os dias, ele matava a minha fome, a da minha filha e do meu marido. Eu levava um potinho e ele colocava de tudo e não me cobrava nada. A colega dele me deu dois pacotes de leite fechado, eu comprava o açúcar e ia ao bar para pegar água quente e fazer a mamadeira. Era assim que a gente vivia. Então eu peço para as pessoas que tem a sua casa dar valor àquilo que tem. A gente não precisa de luxo e nem de riqueza, é só pensar nas pessoas que não tem nada disso. Muita gente está na rua não porque quer, e sim porque aconteceu"wi (Héstia, vivendo na rua, 37 anos). 
As estratégias desenvolvidas pelas mães, em meio ao dramático cotidiano nas ruas, envolvem ainda a capacidade inesgotável de adaptação e reinvenção da vida, como exemplifica o relato de Héstia acima. Observamos que a maternidade na rua acentuaria ao que parece, a sensibilidade do Outro Distante em relação à mulher nessa condição, representada pela atitude benemerente.

O caso de Dóris, abaixo, ilustra igualmente algumas das muitas dificuldades enfrentadas pela mulher vivendo na rua, em que é possível perceber a coexistência de situações complexas como gravidez/maternidade, violência, relacionamento familiar conturbado, preconceito, vulnerabilidade e carência de recursos para subsistência. Dóris relata ainda, assim como o fez Héstia, a problemática do sustento material e do cuidado com a criança, além de referir-se a instabilidade do trabalho informal a que pessoas em situação de rua, como ela, estão sujeitas cotidianamente:

"Eu acho que era às cinco e meia da manhã, porque eu ficava com medo e dormia sempre perto de uma padaria, na porta da padaria e ficava lá até a padaria abrir e quando ela abria, eu saía de lá porque eles pediam para sair. Tinha gente que jogava até água quente na gente... Às vezes eu comia e outras vezes não. Uma vez eu tentei voltar para a casa da minha mãe e ela falou que eu estava magra e alta, e realmente eu estava magra e alta porque com o dinheiro que conseguia eu só dava para comprar Miojo e cozinhar com água quente. Na rua eu tive anemia, mas agora eu to curada, e só curei quando eu engravidei dela (mostra a criança ao lado). Quando eu engravidei dela eu tive que ficar internada mais dias 
porque eu tinha que tomar sangue e soro. Até no dia que eu saí do hospital que eu tive ela, a minha mãe me humilhou dentro do hospital falando para mim que podia me abandonar lá dentro com ela, porque eu só podia sair com a assinatura dela. Eu falei para ela - a senhora que sabe e a consciência é sua e depois você sabe o que Deus pode fazer com você! Foi só isto que e falei para ela. Minha mãe não gosta de mim e nem dela (...). Agora eu arrumei um mercado que eu fico pedindo para olhar os carros e então eu consigo arrumar algumas coisas e quando eu consigo compro Danone para ela, porque ela não se dá bem com leite, e então eu compro Danone ou leite Ninho, então quando eu consigo um pouco eu compro Danone e quando consigo bastante eu compro leite Ninho. Para tomar banho tem os lugares aqui para tomar banho ou senão eu vou numas casas e peço para banhar ela" (Dóris, vivendo em albergue, 20 anos).

A história de Dóris ainda é reveladora, além dos conflitos familiares com a família de origem, do duplo papel que assumem muitas mulheres em situação de rua: cuidadora e provedora de sua filha, sem respaldo familiar, nem institucional, à mercê do que se considera como comiseração pública.

No entanto, em meio às dificuldades mencionadas pelas mulheres em situação de rua, devido à condição feminina, muitos relatos, como os de Ariadne e Afrodite, citados abaixo, explicitaram algumas "facilidades" que o fato de "ser mulher" pode oferecer na rua, o que vai ao encontro de relatos do Outro Próximo, homens por nós investigados:

“...Você sendo mulher as pessoas te dão dinheiro. Homem mesmo te dá dinheiro. A mulher é mais fácil de ganhar as coisas. Porque o homem as pessoas falam: 
'não tem vergonha um homem forte deste não vai procurar um serviço?'. A mulher ouve isso, mas é menos. A dificuldade para os homens é que se ele pedir uma esmola ele é xingado. Até mesmo quando o homem cai num albergue as regras são maiores" (Ariadne, vivendo em albergue, 25 anos).

"Por outro lado, [ao lado dos riscos de viver na rua] encontrei até um pouco mais de facilidade quando chegava em algum bar para conseguir uma doação, neste aspecto eu era mais bem tratada [que os homens]" (Afrodite, vivendo em albergue, 24 anos).

Segundo as entrevistadas acima, o fato de ser mulher e estar em situação de rua apresenta condições que favorecem a benemerência do Outro Distante. A expectativa sobre o papel a ser desempenhado pelas mulheres na sociedade parece estar calcada, como já mencionado, no imaginário popular, que atribui à mulher a fragilidade e, desse fato deriva a necessidade de ser provida e protegida. Dessa maneira, tal fragilidade considerada inerente à natureza feminina, atua como uma via de mão dupla: por um lado se constitui como a maior dificuldade a ser enfrentada nas ruas e, por outro, é facilitadora para obtenção de recursos e auxílio das mais variadas formas.

A partir do olhar que o Outro Distante tem sobre homens e mulheres vivendo na rua, a fala de Ariadne é reveladora da associação presente, no imaginário de entrevistadas, entre a figura masculina e o papel de provedor da família. O fato de estar na rua é interpretado, por vezes, de acordo com o que podemos depreender, como uma livre escolha do homem, significando 
que o mesmo opta por não trabalhar e, portanto, ao permanecer na rua seria um sinal de "vagabundagem". Essa diferenciação entre homens e mulheres é apontada pela entrevistada até mesmo em relação às regras de albergues, quando afirma "até mesmo quando um homem cai num albergue as regras são maiores".

Assim, a "natureza" frágil da mulher parece configurar-se no mundo da rua como um campo de negociação em que é possível obter vantagens que a condição feminina oferece.

A "facilidade" mencionada por Afrodite e Ariadne pôde ser observada em um outro fenômeno, por nós denominado de "estada sazonal nas ruas", o qual se caracteriza pela constituição de grupos de mulheres acompanhadas de crianças, que ocupam ruas de bairros de classe alta, na cidade de São Paulo, nos finais de ano, entre as festividades de Natal e Ano Novo. "Acampadas" nas calçadas, dormindo em papelão esticado no chão, com roupas estendidas nos muros, cercadas de crianças, essas mulheres ocupam as ruas, em alguns casos durante o dia, retornando ao local de moradia à noite e, em outros casos, pernoitando nas calçadas nas duas ou três semanas que antecedem o final do ano. Dois grupos, por nós observados nos anos de 2006 e 2007, na Rua Sergipe, em Higienópolis, não contavam com a presença de homens, companheiros ou não, destas mulheres.

Em uma primeira abordagem, feita no ano de 2006, durante a fase de pré-teste, apenas uma mulher concordou em conversar conosco, informalmente, e não admitiu que se tratasse apenas de uma ocupação 
temporária da calçada com o intuito de se favorecer da benemerência alimentada pela época de Natal, em que é comum distribuição de brinquedos, alimentos, roupas. No discurso da ocupante das calçadas, apenas conseguimos perceber que esta não era uma pessoa em situação de rua, quando mencionou viver em um barraco na periferia que teria sido abandonado devido à violência reinante na favela em que morava. Ao ser indagada sobre se preferia estar na rua com os filhos a viver em um barraco, a entrevistada garantiu que na rua, estando exposta com os filhos, ela recebia ajuda e, fechada em seu barraco, em meio à violência, ela e os filhos correriam risco de morte. Declarou ainda, em conversa informal, que não faltava ajuda do "pessoal do posto de gasolina" próximo para utilizar o banheiro e que conseguia água, para banhar os filhos e beber, com o "pessoal do cemitério". Após a conversa com a suposta moradora das calçadas, fomos reconhecer o cenário: a área ocupada fazia divisa com o cemitério da Consolação e tinha ao seu redor comércio ativo com farmácia, bar, lojas e salão de cabeleireiro. Segundo o gerente da farmácia, durante todo o ano, a calçada era ocupada por aquelas mulheres e reiterou várias vezes que estas não consumiam produtos da farmácia e não faziam parte dos clientes do bairro.

A seguir, dirigimo-nos ao bar e, em conversa com o dono do estabelecimento, este nos informou tratar de uma estratégia de mulheres para se favorecerem da benemerência ocasional de fim de ano que toma conta das ruas de São Paulo. Segundo nosso informante, carros de "bacana" costumavam parar por ali, deixando bonecas, carrinhos, roupas, 
alimento. Conclui, ainda, o proprietário do bar, que essas mulheres voltariam para suas casas após o fim do ano e novamente no ano seguinte outro grupo, ou até o mesmo grupo, formar-se-ia no mesmo local.

De fato, nova visita feita ao local, no inicio de janeiro de 2007 , revelou que a calçada antes ocupada, rapidamente havia se esvaziado sem vestígios da ocupação anterior.

No entanto, em dezembro de 2007, retornando ao local, pudemos encontrar um novo grupo que aceitou conversar, informalmente, conosco. Desta vez, assumiram o fato de que "não eram moradoras de rua", mas mulheres que precisavam de ajuda e que estavam em situação difícil e, portanto, ficariam ali em busca da ajuda de pessoas que, na época de fim de ano, "davam coisas" a elas. Desta forma, ao expor sua miséria e apresentarem-se no seu papel de mãe sem recursos, conseguiam atrair atenção pública. Combinamos entrevista para o dia seguinte e ao retornarmos, encontramos a calçada vazia e a informação de que o grupo, sem que soubéssemos o motivo, havia migrado para uma rua desconhecida.

\subsubsection{Relações sociais no mundo da rua e a transversalidade de gênero}

(1) Relações sociais de gênero

Embora, em discursos apresentados anteriormente por mulheres, a presença masculina poderia representar a busca de proteção devido a maior vulnerabilidade das mesmas no mundo da rua, tal posição não é partilhada por outras mulheres da pesquisa. Isto porque, algumas entrevistas relatam o 
distanciamento das mulheres em relação aos homens como uma opção que se explica, em parte, pela associação da figura masculina na rua com "amolação", "bagunça", drogas e violência de gênero.

"Eu não gosto [de ficar em grupo], porque sempre tem amolação. A polícia vem encher. E, eu estando sozinha, a polícia nunca me parou para nada. Às vezes, eu sento em um lugar pego a minha marmita e como. Eu não posso me queixar, porque a polícia nunca me incomodou em nada, mas se a gente está no meio de turma, ela vêem e fazem revista, por isso que eu gosto de ficar sozinha. Eu fico sempre sozinha. Eu vou para o Morumbi caminhando sozinha, volto a pé sozinha de madrugada. Eu não gosto de muita bagunça não... Porque sempre onde tem bagunça tem drogas, "pinga", então é por isso que eu me afasto... Eu não bebo e não fumo, por isso eu gosto de ficar sempre sozinha" (Perséfone, vivendo na rua, 50 anos).

"Não. A gente não quer [a companhia de homens], porque senão vira bagunça e a polícia vem para perturbar a gente. A polícia perturba quando tem homem, porque dai vira maloca. Quando tem homem, eles acham que tem drogas. Eu mesmo, eu não mexo com drogas. Eu fumo o meu cigarro...". (Ártemis, vivendo na rua, 42 anos)

Como constatamos acima, mulheres entrevistadas revelam, ao que parece, a perda de "confiança" nos homens, ao narrar que preferiram a solidão à presença masculina. Tal perda é associada a comportamentos abusivos que incluem violência sexual e, especialmente, uso de álcool e drogas, tornando as mulheres mais vulneráveis, inclusive em relação à ação 
policial, uma vez que identificam os grupos masculinos (que incorporem ou não mulheres) como alvos preferenciais da polícia.

O depoimento de Eurídice reitera tal desconfiança, sobretudo, quando a mesma é decorrente de uma violência de gênero, experimentada no mundo da rua, considerada traumática:

\begin{abstract}
"É um perigo la experiência da rua para as mulheres])...Para nós que somos mulheres. Quando é marido e mulher tudo bem, porque o homem protege a mulher. Agora quando você pensa que tem amigo homem que é morador de rua, eles não respeitam. Eles são safados e sem vergonha, eles aproveitam o momento... Eu tenho tanto trauma de homem, tenho tanta raiva, porque eu confiei e enfim acabou com uma coisa que eu jamais queria, que eu jamais esperava. É muito triste, por isso eu não confio mais em homem" (Eurídice, vivendo na rua,39 anos).
\end{abstract}

Muito embora no relato de Eurídice esta conceba a presença do "marido" como um diferencial na proteção da mulher, o caso de Héstia, abaixo, configura, no entanto, exemplo de exceção:

\footnotetext{
"Nesse dia ele (o marido) tinha bebido uma cerveja com um amigo dele. Ele foi descansar e passou um homem vendendo banana, ele me convidou para sair com ele e me disse que me dava um dinheiro. Eu falei para ele: eu tenho o meu marido, eu não preciso do seu dinheiro... Eu disse: eu só não vou acordar o meu marido agora para não ter confusão pro seu lado. Eu não preciso do seu dinheiro, eu não estou aqui para me prostituir. Se você quiser me ajudar sem intenção nenhuma, você pode me
} 
dar um leite, ou um alimento para a minha filha, mas, sem nada em troca. Eu vou te agradecer muito, mas fora isso muito obrigada, pode procurar outra pessoa. Mas foi só essa vez. Mesmo ele vendo o meu marido deitado ali ele me convidou para sair com ele. Ele falou para eu ir para o hotel com ele que ele me dava $R \$ 50,00$ " (Héstia, vivendo em albergue, 37 anos).

Como podemos observar, a suposta presença protetora do companheiro, na representação de Eurídice, não coibiu, no caso de Héstia, o assédio masculino - de um Outro Distante - e aponta para a associação, no imaginário masculino, da figura feminina vivendo na rua com a obtenção de sexo fácil, presente tanto no imaginário do Outro Distante quanto dos próprios homens em situação de rua - o Outro Próximo.

\section{(2) Relações conjugais, afetivas e sexuais}

A ausência de intimidade, pressuposta pela exposição pública extrema a que as mulheres em situação de rua, assim como os homens, estão sujeitos por viverem em espaço aberto, foi recorrente na fala das entrevistadas, assim como o foi nas falas masculinas já apresentadas. Nesse contexto, a dimensão sexual e afetiva é muitas vezes negada, fato especialmente observado na fala de Perséfone:

"Na rua não tem nem como fazer amor, em casa é diferente, muita coisa rola entre quatro paredes. Eu não concordo em ter um namorado na rua... Eu acho que não, porque eu já morei muito tempo sozinha e nunca tive namorado não. Eu não tenho muita paciência, acho 
que sozinha é melhor. Eu acho que eu não nasci para casamento não. Eu nasci para ficar sozinha. Eu e o rádio..." (Perséfone, vivendo na rua, 50 anos).

Ao verbalizar que "na rua não tem nem como fazer amor, em casa é diferente, muita coisa rola entre quatro paredes", Perséfone revela-nos que a prática sexual é o espaço da intimidade, mas que tal intimidade passa, no seu imaginário, pela idéia do amor romântico, em que relações sexuais não se desvinculam de relações afetivas.

Se para Pierret (1998), a sexualidade é considerada como âmago da intimidade, podemos inferir que, no mundo da rua, a impossibilidade da vivência sexual na privacidade leva as mulheres ou à negação dos envolvimentos afetivos e sexuais, ou à busca de estratégias no sentido de recriar a privacidade no espaço público:

"[A gente] faz embaixo das cobertas, em um lugar onde não passa muita gente. Esse neném que eu estou esperando foi feito na rua..." (Héstia, vivendo em albergue, 37 anos)

"Ah! Tem os mocós da vida, né? Que nem eu mesmo, sempre fui reservada, nunca gostei assim... porque tinha amiga que às vezes estava dormindo assim o montinho na calçada, ali mesmo tinha relação. Muitas vezes, de madrugada, passava gente, e percebia o que estava acontecendo. Mas no meu caso, eu sempre fui reservada. Quando arrumava namorado e ia ter relação assim, tinha os mocós dentro da ponte, ali na Consolação - que tinha muito e agora tamparam - a gente dormia lá dentro. Então a gente saía para um canto mais reservado, entendeu? Vagão de trem no 
Brás... Então era sempre em um lugar reservado. Mas tem colegas minhas que não estavam nem aí... Era na calcada, em qualquer lugar ..." (Deméter, vivendo em albergue, 23 anos).

Deméter, ao relatar as particularidades da experiência de vida nas ruas, permite-nos identificar a fluidez que caracteriza as relações nesse contexto - sejam elas sexuais e/ou afetivas -, ao mesmo tempo em que revela como se dá, em muitos casos, a trajetória de homens e mulheres desde o momento em que se conhecem até quando se dizem "marido e mulher":

"Se você namora em casa, é tudo nos conformes, entendeu? Você tem horário para tudo, você tem sua mãe do lado para estar te orientando, o que você deve ou não deve fazer. E na rua, você mal conhece a pessoa e ele já se torna seu marido, não é mais namorado, é marido. Não tem namoro, ele se torna seu marido. Ah! Elas [as mulheres] falam assim para as pessoas dali: é o marido. Mas entre ele ou ela, em troca de carinho é Mô ou Fio, ou pelo nome. É assim..." (Deméter, vivendo em albergue, 23 anos).

O exercício da sexualidade para as mulheres, no mundo da rua, parece não se configurar como um espaço de liberdade igualitária para homens e mulheres, uma vez que na lógica das relações presentes neste cenário, as mesmas são recriadas, cabendo a mulher a negação do "amor romântico", representado no caso de Deméter pela menção à ausência do namoro. Tal fato significaria, em seu imaginário, a inversão da lógica, da temporalidade presente no processo de aproximação que leva homens e 
mulheres a decidirem viver juntos uma relação conjugal, de "marido e mulher", conforme sua referência e, na qual tal concepção faz parte do imaginário social (Heilborn, 2004).

A intimidade sexual e afetiva, reinventada no cenário na rua, não ignora casos mencionados, também por Deméter, de amigas, quando afirma: "Mas tem colegas minhas que não estavam nem aí...[As relações sexuais] era[m] na calçada, em qualquer lugar ...".

Isso representa que nem sempre essa moralidade presente em nossa cultura, que leva mulheres como Perséfone, ao que parece, negar os envolvimentos afetivos a ponto de se privar até mesmo do contato mais próximo com homens, em relações de sociabilidade, seja pratica generalizada. Pelo contrário, podemos, a partir de outros relatos, observarmos a diversidade de comportamentos e vivências da sexualidade no mundo da rua.

Se tais questões se fazem presentes para mulheres vivendo na rua, o mesmo se dá para "casais" que optaram por viver em albergues. As regras que ordenam o funcionamento de muitas dessas instituições parecem não considerar a vida sexual e afetiva até mesmo de parceiros estáveis, como nos mostra a narrativa de Héstia:

"A gente sabia só que a gente queria um albergue que aceitasse o casal, para a gente poder ficar junto. A gente não queria um albergue para dormir separado. Aqui [no albergue] nós não dormimos juntos... Lá no B. tem o albergue $N$. que o casal não dorme separado, cada um tem o seu quarto. É melhor porque a gente não tem relação sexual, não tem nada, é só um beijinho porque 
eles não podem ver. Na rua a gente sempre dá um jeitinho. Se a gente quiser ter um momento íntimo, nós temos que ir até a assistente social e pedir autorização para sair. A gente não pode sair sem falar nada e passar a noite na rua. Perde [a vaga]. Então a gente tem que pedir autorização. A gente sai e vai para um hotel. A gente sempre junta um dinheirinho e dá um jeito de ir para um hotel. Aqui, raramente dá para conversar coisas intimas e pessoais, porque sempre tem alguém do lado" (Héstia, vivendo em albergue, 37 anos).

A prática de pagar por um quarto de hotel, quando se deseja ou se pode ter uma relação sexual, parece ser a opção mais utilizada por homens e mulheres tanto vivendo nas ruas, quanto em albergues, conforme observamos nos relatos de ambos.

Dessa forma, a idéia de conjugalidade na modernidade tardia pressupõe como critério definidor, a partir de Giddens (1993), a reciprocidade no dar e receber afeto, no contexto da intimidade, o que implica equidade de gênero, difícil de ser observada no cenário da rua, dadas as condições objetivas e subjetivas de existência nesse cenário. No entanto, a idéia da mesma encontra-se expressa em um sistema de troca no qual ao homem é permitido ter uma mulher como "esposa", que dele cuidasse como contrapartida à proteção oferecida, sobretudo em relação à violência sexual.

Para que haja igualdade entre homens e mulheres no espaço da intimidade, Souzas e Alvarenga (2001) afirmam ser importante que ocorram transformações sociais que garantam o exercício do direito e da afetividade 
presentes como conquistas sociais e políticas em nível da sociedade mais ampla. Daí, podermos inferir que a mulher, ao se inscrever no mundo da rua, se afastaria das possibilidades de uma vivência mais igualitária entre pares.

\section{(3) Albergues: entre a rua e a casa ?}

Novac e col. (1996) entendem ser paradoxal o comportamento das mulheres canadenses vivendo em situação de rua, na medida em que estas preferem a proteção de um homem na rua a recorrer a instituições e programas governamentais, como albergues. Os discursos das mulheres em nossa pesquisa, quer estas vivendo nas ruas ou em albergues, permitem compreender o porquê da preferência de muitas pela vida na rua.

A opção das mulheres pelo albergue parece relacionar-se com o que Nasser (2001) constata acerca do significado deste para homens em situação de rua, na cidade de São Paulo:

"De um lado [o albergue] é um espaço que se diferencia da rua, pois nele todos estão protegidos do clima frio e chuvoso da cidade [...], da violência, e principalmente serem confundidos com os mendigos, já que tem uma cama para dormir, uma sopa quente no jantar e condições de asseio do corpo e das roupas. Por outro lado, e ao mesmo tempo, o albergue é um espaço que não se confunde com a casa, uma vez que nele se estabelecem relações de convivência, e não relações pessoais [...]" (Nasser, 2001:127)

O albergue se apresenta, segundo a autora, como uma mediação entre a casa e a rua, especialmente na representação de migrantes. Em 
nossa pesquisa, o albergue parece apresentar-se para algumas mulheres não somente como um espaço transitório, mas também como uma sinalização da idéia de não pertencimento à rua e ao mesmo tempo o sentirse em um ambiente doméstico, próximo ao da casa, como coloca Hera:

\begin{abstract}
"É muito bom e tranqüilo. A gente chega, toma um banho, janta, assiste televisão e descansa. As pessoas respeitam a gente e não tem briga. Não é como se fosse a minha casa, mas é bom...Eu acho que está bom, como está. Por ser um albergue, está bom" (Hera, 43 anos, vivendo em albergue).
\end{abstract}

Tal concepção do albergue, como um local de moradia próximo à idéia do cotidiano vivido, normalmente em ambiente doméstico, encontra-se presente também no relato de Afrodite e, em outra passagem, do depoimento de Hera, ambas vivendo em albergue e trabalhando "fora".

Hera bem ilustra um novo estilo de vida para pessoas desprovidas de moradia, em que observamos o sentimento de não pertencimento ao mundo da rua, quando afirma:

(Sobre o dia fora do albergue) "Eu vou para a oficina. Eu trabalho na Arte e Luz da Rua, onde eu faço luminárias de tela de arame. Eu fico lá na Casa de Oração e na oficina. Isso é uma frente de trabalho do Governo do Estado. Todos os meses são depositados um salário e é dado um cartão de cesta básica. Eu passo o dia lá, é muito bom... Já faz dois anos. Mesmo quando acaba a frente de trabalho a gente continua lá. Não ganha o suficiente para pagar um aluguel, mas já dá para manter e a gente não fica na rua. A rua é muito sofrida, na rua o 
pessoal sofre muito".(Hera, vivendo em albergue, 43 anos).

"Isso [optar pelo albergue] vai muito do ponto de vista. Para mim, aqui está sendo bom, porque tem um lugar para dormir, para comer, a refeição é boa. Mas o que eu acho, em linhas gerais - e já que é uma pesquisa voltada para este assunto - o que falta muito, não só aqui, mas também no de $\mathrm{O}$. onde eu passei e que segue o mesmo padrão, é um programa eficaz de inclusão social. Porque o que eu observei aqui é que as pessoas que vêm para cá são pessoas que estão acostumadas a viver de esmolas. Este não é o meu caso, como eu já te falei, porque eu tive uma estrutura" (Afrodite, vivendo em albergue, 24 anos).

Tanto Afrodite, como Hera, narram aspectos positivos que consideram da instituição, reforçando o papel do albergue como uma espécie de moradia alternativa para homens e mulheres que, por circunstâncias diferenciadas de existência, acabam "caindo" no mundo da rua. Essa visão do albergue, representando um espaço potencial em que seria possivel recriar a privacidade de um lar, com a idéia de uma moradia barata e o apoio do Estado, pode ser exemplificado pelo discurso de Perséfone, vivendo na rua:

\footnotetext{
"Eles deveriam cobrar uma taxa por pessoa e fazer vários quartinhos ao invés de ser de graça e ser tudo junto. O maior problema é que fica todo mundo junto dentro do quarto, se você deixa alguma coisa você pode ser roubado; todo mundo reclama disso. Os banheiros
} 
são poucos. Tem fila para tomar banho, para jantar; tem fila para tudo. Eu acho que eles deveriam cobrar uma taxa, mas fazer um quarto com banheiro para cada pessoa. Porque com todos que eu converso falam isso, eles poderiam cobrar até cem reais por pessoa, porque com latinha a gente consegue pagar esse valor. Eu já cansei de falar isso para aquelas pessoas que vêem com as Peruas, e todos falam a mesma coisa. Porque a gente não tem liberdade nenhuma. A gente tem hora para chegar, hora para sair. Eles deveriam fazer do jeito que eu estou falando: alugar os quartinhos e não colocar hora para chegar e sair. Porque eu mesmo cato latinha, então de sexta para sábado eu não durmo, passo a noite catando latinha" (Perséfone, vivendo na rua, 50 anos).

A narrativa de Perséfone permite-nos melhor aproximação para responder a indagação de Novac e col. (1996), uma vez que ao optar por viver na rua, não rejeita a idéia de viver em um albergue, desde que este propicie a idéia de privacidade e liberdade que considera fundamental.

Embora possa parecer um paradoxo, em seu discurso podemos desvelar que a mesma, assim como outras mulheres nas mesmas condições, sentir-se-iam mais seguras na rua do que vivendo em albergues. A questão, portanto, não é de simples abrigo, mas sobretudo de privacidade, segurança e liberdade para recriar o cotidiano conforme as demandas e necessidades individuais: "Porque a gente não tem liberdade nenhuma. $A$ gente tem hora para chegar, hora para sair. Eles deveriam fazer do jeito que eu estou falando: alugar os quartinhos e não colocar hora para chegar e sair. Porque eu mesmo cato latinha, então de sexta para sábado eu não durmo, passo a noite catando latinha". 
Assim, a ausência de liberdade para organizar o tempo, as atividades cotidianas e a restrição de movimento no espaço interno da instituição constituem-se nas principais queixas observadas nos discursos tanto de mulheres albergadas, como nos de mulheres em situação de rua. Ganha relevância nesse contexto, os horários impostos para café da manhã, almoço e jantar que aparecem como arbitrários e distantes do idealizado por entrevistadas:

"A gente não tem o que reclamar daqui, a única coisa é a televisão, porque eu gosto de assistir uns programas. $O$ ruim prá gente é isso, porque aqui a gente não pode mexer em nada. A gente tem horário para janta, o ruim é isso. Agora dentro da casa da gente não tem isso, a gente pode acordar e fazer um leite para o menino sossegado, a gente pode comer na hora que quer, pode fazer aquilo que a gente quer comer. Ele está até com saudades de poder cozinhar, porque ele adora cozinhar. Fora isso eu não tenho do que reclamar daqui. Aqui é bom, a gente tem banheiro para tomar banho, tem onde a gente dormir, tem o que comer, a única coisa é que tem horários para tudo" (Hebe, vivendo em albergue, 30 anos).

"Porque lá [no albergue] tem horário para tudo. Não, não é muito ruim, mas tem que seguir as normas deles. Pelo menos na rua eu vou onde eu quero, na hora que eu quero, chego na hora que eu quero, durmo na hora que eu quero e lá não, lá tem horário para tudo. Não dá certo, para mim não dá” (Éris, vivendo na rua, 50 anos).

"Você não tem direito a ligar um rádio. Você até pode, mas se você ligar você incomoda a outra pessoa a 
dormir. Se a pessoa é mais nervosa do que você ela xinga você. Deu para entender?" (Eunice, vivendo em albergue, 36 anos).

Ao lado do sentimento de ausência de liberdade, o albergue também é associado à sujeira, à bagunça e à insegurança, segundo Perséfone e Calíope

"Da primeira vez eu procurei [albergue], mas agora eu não quero ir. Eu não gosto porque é muita "bagunça", muita sujeira. O banheiro é sujo, tem fila para tudo. Para ficar no albergue é melhor ficar na rua, porque tem a Casa de Convivência, a gente pode ir lá tomar banho, pode lavar a roupa, tem comida" (Perséfone, vivendo na rua, 50 anos).

"Sujeira, lugar sujo... Têm pessoas que precisam mais do que eu... Semana passada eu fui a um e vi que a cama estava com problemas, ela balançava muito e eu até fiquei com medo de cair da cama. Não é organizado não. É sujeira. É sujo mesmo (Calíope, vivendo na rua, 41 anos).

"Eu não gosto de albergue... Porque eu tenho medo. Eu não gosto de ficar na rua... Eu tenho medo [do albergue] porque sai muita briga. Eu gosto de ficar mais aqui com as meninas, porque uma olha a outra... Quando eu estou dormindo, ela me olha e quando ela está dormindo eu a olho" (Ártemis, vivendo na rua, 42 anos).

Das falas acima, de mulheres que "optaram" por viver na rua e não em albergues, podemos depreender que o mesmo não oferece nem a 
segurança esperada, nem o que as mesmas consideram importante: um local limpo onde pudessem "viver", dormir e tomar banho. A Casa de Convivência, de acordo com Perséfone, responderia mais as suas necessidades, mesmo que não ofereça pernoite. A ambigüidade presente nesta fala é ilustrativa mais uma vez da idéia presente de que a rua, em muitas situações, seria mais segura, além de permitir a escolha livre de com quem se deseja ficar.

Em relação à higiene pessoal das mulheres, que se mostrou importante em nossa pesquisa, o mesmo foi observado por Reeve e col. Segundo as autoras, tal preocupação é constante, por parte de mulheres homeless na Inglaterra, especialmente no que diz respeito ao banho. Nesse cenário inglês, isto se deve ao fato de que para mulheres em situação na rua, o asseio e a limpeza se constituem em motivo de orgulho e um sinal de diferenciação que as preservariam da identificação com uma mulher vivendo na rua (Reeve e col., 2007:53).

Quanto à exemplificação da forma como a violência pode ocorrer em albergues, independentemente da condição de ser homem ou mulher, a fala de Eurídice apresenta-se como exemplar, na medida em que nos permite visualizar problemas de relacionamento que emergem em função de uma situação sentida como de confinamento, em meio a diversidade de sujeitos que dividem o mesmo espaço fechado:

"Eu já vi coisa acontecer dentro de albergues que olha! Já saiu até morte dentro do albergue... São essas mulheres bandidas que arrumam encrenca e depois 0 marido entra no albergue e mata. Um cara entrou vestido 
de mulher, bem disfarçado e ficou observando, a mulher estava deitada e ele colocou o travesseiro na cabeça dela e esfaqueou ela toda. A mulher dele estava grávida e arrumou encrenca com a outra. Ela chegou toda machucada, a criança viu e perguntou: "O que foi isso?" Ele estava preso, quando ele saiu da cadeia ele se vestiu de mulher disse: "Deixa comigo, nem que for no inferno eu acho ela." Ele procurou até achar e quando achou a matou... No B. também mataram uma pobre coitada apunhalada pelas costas; ela estava acabando de comer um pão para ir lavar a roupa, deram vinte e poucas facadas nela" (Eurídice, vivendo na rua, 39 anos).

Nesse sentido, a dificuldade de convivência, ao que parece pelo excessivo número e diversidade de indivíduos, coloca-se igualmente como questão fundamental:

"Para ser sincera não é bom. Só é bom porque você não fica na rua, no frio. Lá você almoça, toma café, se você fica doente eles chamam o SAMU e levam você para o médico, mas é triste, não é fácil não. É que mistura todo tipo de gente, sai briga. Tem muitas pessoas que procuram briga, eles te roubam. Eu mesma já perdi muita coisa dentro de albergue [...] Deveria ter albergues só para mulheres. Pessoas que fossem mães, que tivessem familias e que não tivessem vício de nada. Uma casa que apóie. Que tenha um funcionário de confiança para pegar as crianças, cuidar, levar para a escola, para a gente poder trabalhar. A gente trabalhava por uns seis meses, ia juntando um dinheiro e depois arrumava um lugar para morar, poderia até comprar um terreno, montar um barraco para poder morar. Eu acho que deveria ser assim, eles apóiam a gente, mas é tudo misturado, vira uma bagunça, as pessoas mexem nas 
suas coisas, você não tem sossego. Você deita e não sabe se vai acordar viva, porque tem mulher de todo tipo, drogadas, viciadas, bandidas, tem tudo" (Eurídice, vivendo na rua, 39 anos).

Vale mencionar o discurso de que a atuação de funcionários é reconhecida pela compreensão, interesse e disponibilidade, o que apontaria para a importância do acolhimento e do papel que o albergue pode representar como verdadeiro espaço entre a rua e a casa:

\footnotetext{
“Esse albergue é muito bom. Quanto aos funcionários eu não tenho do que me queixar, o problema são os moradores mesmo... Isso, a falta de respeito, a falta de humildade. A minha filha todo o dia depois do almoço gosta de dormir, mas ela não consegue porque as pessoas ficam gritando, conversando alto. O maior problema são os moradores. As pessoas que trabalham aqui dentro, as assistentes sociais, todos são legais e compreendem a situação da gente" (Héstia, vivendo em albergue, 37 anos)
}

A importância da casa - em alguns casos, do emprego - presente no imaginário das mulheres como o grande sonho a ser atingido permite-nos refletir sobre em que termos a saída dessas mulheres do mudo da rua seria possível e através de que caminhos.

\subsubsection{Da rua para casa: um sonho possível?}

Segundo Rowles (2006), a palavra casa simboliza nosso sentido de pertencimento, nosso senso de identidade, além de representar o local de 
segurança e funcionar como o ponto central, a partir do qual nos orientamos em relação ao mundo. Nesse sentido, a casa nos remete ainda, de acordo com o autor, a estados de bem estar físico e psicológico que estariam interligados a história pessoal e ao entorno geográfico e humano em que cada indivíduo vive ou viveu.

Entendida dessa forma, as implicações ocasionadas pela ausência de uma "casa", no caso de pessoas em situação de rua, ainda têm sido subestimadas nos estudos sobre essa população. Tal fato se apresenta especialmente relevante em se tratando de pesquisas sobre mulheres em situação de rua.

Thomas e Dittmar (1995), em artigo que discute o significado que mulheres em situação de rua atribuem à "casa", identificou a dificuldade que estas apresentaram em distinguir a casa física, construída materialmente, da casa simbólica, como Rowles (2006) a concebeu. Para as autoras, mulheres que nunca tiveram a experiência de vida na rua conseguiam verbalizar claramente a diferença entre a casa-construção e a casa-lar ${ }^{23}$, ao contrário do observado nos discursos de mulheres em situação de rua.

Em nossa pesquisa, a categoria "casa" emergiu quando as mulheres em situação de rua foram indagadas sobre seus desejos e sonhos. Muitas entrevistadas declararam que "ter uma casa" seria seu maior sonho. Mas a que casa essas mulheres se referem?

\footnotetext{
${ }^{23} \mathrm{Na}$ língua inglesa a diferença entre os aspectos materiais e simbólicos de casa são facilmente identificados pelas palavras house e home, respectivamente, o que não acontece na língua portuguesa.
} 
"[Casa] significa muita coisa. Quando a gente tem casa a gente pode tomar banho a hora que a gente quiser, pode lavar a roupa na hora que a gente quiser; casa é muito bom! Eu estava tentando ver uma casa lá em Itaquera, porque a prestação é mínima, é cento e pouco reais, mas primeiro quero arrumar a vida. Primeiro eu quero o meu quartinho para depois ver isso, se der certo aí eu vou" (Perséfone, vivendo na rua, 50 anos).

"Eu não sou de sonhar muito, eu me contento com pouco. O meu sonho é ter uma casa que coubesse pelo menos uma cama para a minha filha dormir e um fogão para eu cozinhar, isso já seria o suficiente. Não precisa ser aquela mansão. É lógico que isso é para começar, e depois a gente vai arrumando uma casa maior aos poucos" (Héstia, vivendo em albergue, 37 anos).

"Ah, filha, tem uma grande diferença na casa e na rua, e tem horário para tudo! Então tem almoço, jantar, banho, aconchego, a caminha limpinha, a casa limpinha. Nossa! Tem uma grande diferença. Na rua a gente improvisa qualquer coisa, qualquer coisa que vem a gente improvisa, e não tem aquele aconchego que tem em casa, dentro de quatro paredes. Tem a segurança, e na rua a gente deita e não sabe se amanhece" (Éris, vivendo na rua, 50 anos).

"Tem mais privacidade. Você tem um canto. Você pode fazer uma comida. Tem tempo para assistir televisão a hora que quer, faz o que quer. Aqui não pode ligar uma televisão, você tem que dormir na hora que é para dormir. Na casa da gente a gente é livre" (Eunice, vivendo em albergue, 36 anos). 
Nos discursos acima, a "casa" narrada pelas entrevistadas inclui aspectos que mesclam a casa-material e a casa-simbólica. Nessa linha de raciocínio, podemos supor que a mulher em situação de rua parece se referir a casa "em sua realidade e em sua virtualidade, através do pensamento e dos sonhos", como pressupõe Bachelard (2005).

Somerville (1992) sugere que existem diferenças no significado de "casa" para homens e mulheres. Tais diferenças, segundo o autor, assumem especificidades se relacionadas à condição de rua para ambos, no seguinte sentido: "embora a situação de rua signifique miséria para homens e mulheres, esta toma a forma de privação emocional para homens, enquanto que, para mulheres, significa a perda do papel doméstico" (Somerville, 1992:535).

Se considerarmos a assertiva de Somerville, mulheres em situação de rua, tenderiam a se sentir desorientadas na medida em que o viver na rua significaria a perda das referências fundamentais, dadas pelo gerenciamento e desempenho das atividades domésticas cotidianas, especialmente relevantes no caso das camadas populares nas quais a organização da vida doméstica é um importante elemento para a construção de suas identidades.

Assim, a casa adquire o "status simbólico", na acepção de Somerville (1992), que passa a representar, para as mulheres de nossa pesquisa, o sonho da casa construída e, ao mesmo tempo, configurar-se como o espaço potencial para o encontro com a liberdade, com o conforto, com a privacidade, na qual se tem "almoço, jantar, banho, aconchego, a 
caminha limpinha, a casa limpinha" - como afirma Éris - e um local de "privacidade" e liberdade, conforme Eunice.

O significado da casa como representação do sentido da vida fora da rua é sintetizado por Caliope, quando afirma:

"[A casa] significa tudo. Paz, harmonia, amor, capricho, despesas, uns mil itens. Tem que estar limpa, arrumada, bem pintada. Uma porta bem arrumada. Alegria. Tudo vai! Tudo o que é bom. Tudo o que é ótimo!" (Caliope, vivendo na rua, 50 anos).

Novac e col. (1996) em pesquisa sobre mulheres em situação de rua no Canadá, onde as autoras identificaram "uma variedade de significados para "casa" que incluía condições materiais, sentimentos de bem-estar físico e emocional, espaço para relações sociais amorosas, controle e privacidade [...]"(Novac e col., 1996:8).

Chama-nos a atenção que, na casa sonhada por mulheres de nossa pesquisa, não há menção a seus companheiros ou a qualquer presença masculina. O sonho e a casa são delas.

Se a casa se apresenta nos sonhos e desejos das mulheres como o fim último, os meios para alcançá-la somente são relatados em alguns depoimentos em que o emprego ganha também estatuto de sonho:

"Essas pessoas mais sofisticadas, essas madames. No lugar onde a gente vai almoçar tem uma fila e a gente fica esperando abrir, quando elas passam elas falam: "esses indigentes, esses sem teto". Elas falam que a gente está colocando doença na cidade... Isso me entristece, porque eu tenho vontade de sair da rua. O meu maior sonho é conseguir uma vaga fixa e um 
emprego. Se a senhora agora me falasse: "quer trabalhar, quer ir para a minha casa?", eu pegava as minhas coisas e iria correndo. Não pensaria duas vezes. O meu maior sonho é arrumar um emprego em uma casa de familia para dormir no emprego. A rua não presta, tem muita coisa ruim, tem muita gente boa na rua, mas tem gente má também" (Eurídice, moradora de rua, 39 anos).

Se Eurídice vê no emprego a forma para resgatar sua dignidade como cidadã; Afrodite, no depoimento abaixo, após passagem em dois albergues, reflete como o poder público e instituições poderiam juntos investir na formação profissional das pessoas em situação de rua, para que estas tivessem condições de reinserção no mercado de trabalho. Fala, em suma, da importância de uma política pública na qual o albergue poderia representar de fato o caminho entre a rua e a casa:

"...Mas o que eu acho, em linhas gerais - e já que é uma pesquisa voltada para este assunto - o que falta muito, não só aqui [no albergue], mas também no de O., onde eu passei e que segue o mesmo padrão, é um programa eficaz de inclusão social. Porque o que eu observei aqui é que as pessoas que vêm para cá [albergue] são pessoas que estão acostumadas a viver de esmolas. Este não é o meu caso, como eu já te falei, porque eu tive uma estrutura. Eu acho que falta um programa para essas pessoas que não receberam essa estrutura que eu tive, de terminar o ensino médio, falta uma estrutura que reeduque essas pessoas para que elas possam voltar. Porque as pessoas que vêm para cá - e me dou como exemplo disso, porque se não fosse tudo isso que eu já 
te falei, talvez eu me acostumasse também. Talvez eu falasse para você: "Eu quero passar seis meses aqui, seis meses em um outro e assim vou levando a minha vida", que é o acontece com os moradores de albergues. Eu acho que falta um programa assim dentro da atualidade. Isso eu notei aqui, notei no outro que eu passei e acredito que os demais sejam da mesma forma (Afrodite, 24 anos, moradora de albergue).

No depoimento de Afrodite, vale destacar a idéia de que o sair da rua para a casa implica em se pensar o albergue como espaço de transição, uma vez que o mesmo pode se constituir no que considera um "modo" ou "estilo de vida' para parcela dessa população de rua, excluída do mercado de trabalho e sem possibilidade de nele se inscrever.

Nessa mesma linha de reflexão, Héstia aponta a importância do albergue como política de Estado, voltada para a inclusão social, em que a questão da formação profissional com vistas à inserção no mundo do trabalho passaria representar a autonomia desejada pelas mulheres, mas não somente para elas:

"Eu pediria trabalho para os moradores de rua. Dar oportunidade para eles saírem da rua. Não adianta enfiar todo mundo nos albergues e não fornecer serviço, eles saem daqui e vão para a rua beber, vão passar o tempo até dar a hora de voltar. Aqui só fica quem é doente que não pode ficar na rua mesmo, mas o resto dos homens são só doze horas mesmo. Se a pessoa não tem serviço eles ficam na rua esperando o tempo passar. Poderia ser até um trabalho de reciclagem, eu mesma já trabalhei com reciclagem, conheço todos os tipos de materiais. Eu 
acho melhor eles darem trabalho e oportunidade para as pessoas poderem sair e juntar o seu próprio dinheiro.

[... "Eu acho que para melhorar eles deveriam colocar um curso aqui dentro... Um curso para as mulheres se animarem a fazer. Um curso de culinária, crochê, tricô, isso não tem. Só tem curso de costura, de padeiro e de cabeleireiro. Lá não trabalha nenhuma pessoa que mora aqui dentro, que faz curso lá. Parece que é gratuito, eu não sei... Eu não me interesso por corte de cabelo. Agora se tivesse curso de manicure, de crochê, eu me interessaria...Porque para a gente arrumar um emprego em um salão de beleza, você tem que ter o diploma do curso na mão." (Héstia, vivendo em albergue, 37anos).

Se a saída da casa de origem para a rua representou, no caso das mulheres investigadas, a busca da liberdade em relação a uma situação de opressão vivida no ambiente doméstico - em que a motivação para a saída teria sido o sentimento de viver "sem casa dentro de sua própria casa" - , a rua não representaria, como pudemos observar, necessariamente uma nova forma de vida desejada, mas uma situação contingencial. Isso porque, considerando a opressão de gênero e a tradicional concepção patriarcal da dependência feminina em relação a um provedor - homem -, a questão da autonomia da mulher deve ser pensada como relativa em nossa sociedade, o que a torna mais vulnerável quando do rompimento de laços familiares e/ou rede de apoio.

Nesse sentido, a concepção de "casa" para muitas mulheres em situação de rua é construída, segundo Wardhaugh (1999), mediante experiências biográficas, marcadas por abusos, violência e opressão. A 
partir dessa perspectiva de Wardhaugh, podemos pensar que a casa sonhada por nossas entrevistadas parece representar, em seu aspecto simbólico, o não vivido, o desejado, o sonho de "segurança" e "fuga/saída", em oposição às experiências traumáticas sofridas por essas mulheres. 


\section{CRUZANDO OLHARES, ABRINDO QUESTÕES.}

"Até que o sol não brilhe, acendamos uma vela na escuridão".

Confúcio

Ao cruzarmos os olhares sobre a mulher vivendo em situação de rua dos três grupos por nós entrevistados - o Outro Distante, "o Outro Próximo" e as próprias mulheres em situação de rua -, observamos que os relatos apresentados em cada um desses grupos podem ser compreendidos nas suas especificidades e aproximações. Apontam, assim, no sentido de se considerar a vida na rua como reveladora da diversidade não só de processos de sociabilidade, mas também de sujeitos sociais e trajetórias de inserção no mundo da rua, que permitem pensar na experiência do viver na rua como espaço constitutivo de um modo de vida em que o "nós", e os "outros", ora se contrapõem, ora se aproximam, em uma dinâmica própria. Em relação à dinâmica das relações sociais, no mundo da rua, a aproximação às reflexões de Simmel sobre a concepção de estrangeiro apresenta-se como heurística, em termos de interpretação. Para esse autor, o estrangeiro é como um viajante que se fixou

"em um grupo espacial particular, ou em um grupo cujos limites são semelhantes aos limites espaciais, mas sua posição no grupo é determinada, essencialmente, pelo fato de não ter pertencido a ele desde o começo, pelo fato de ter introduzido qualidades que não se originaram nem poderiam se originar no próprio grupo. A unificação de proximidade e distância envolvida em toda relação humana organiza-se, no fenômeno do estrangeiro, de um modo que pode ser formulado de maneira mais sucinta dizendo-se que, nesta relação, a distância significa que ele, que está próximo, está distante; e a condição de estrangeiro significa que ele, que também está distante, na verdade está próximo. [...] O estrangeiro está 
próximo na medida em que sentimos traços comuns de natureza social, nacional, ocupacional, ou genericamente humana entre ele e nós. Está distante na medida em que estes traços comuns se estendem além para além dele ou para além de nós, e nos ligam apenas porque ligam muitíssimas pessoas" (Simmel, 1983: 182-183; 186).

Enquanto membros de grupos vivendo no mundo da rua, homens e mulheres que chegam nesse cenário apresentam-se, num primeiro momento, como estrangeiros, na medida em que encontram um modo de vida próprio, diverso de suas origens, por ainda não terem pertencido ao mesmo, portanto, não terem sido socializados segundo suas regras. Isto muito embora, no caso desse grupo sócio-populacional, seus membros partilharem, no geral, de normas e valores sociais nos quais se apresentam traços da ordem patriarcal ainda vigentes na sociedade brasileira e nas camadas sociais de origem. Neste sentido é que podemos entender como aspectos das dimensões micro e macrossociais se entrecruzam, numa totalidade social que articula simultaneamente as dimensões subjetivas e objetivas constituintes do sujeito social. Por isso, nas palavras de Norbert Elias, a importância de rompermos com a dicotomia indivíduo-sociedade a partir de uma perspectiva que se conceba a sociedade como "sociedade dos indivíduos" (Elias,1994).

Esse mundo da rua se configura como uma instância socializadora no qual novas relações se estabelecem e passam, a partir dos olhares próximos e distantes, a construir novas identidades, novos sujeitos. Consideramos que tal processo não se circunscreve necessariamente à questão do tempo de permanência na rua, mas, especialmente, pela forma 
como mulheres e homens, supostos estrangeiros, chegam e se identificam com esse modo de vida. Entendemos, assim, podermos dotar de novos significados a tipologia de Vieira e col. (2004) relativa às categorias de sujeitos presentes nesse cenário, quais sejam, o ficar na rua, o estar na rua e o ser da rua.

Estrangeira também é a população em situação de rua, no olhar da sociedade que a interpreta, de um modo geral, como um conjunto de seres humanos que se desviam da ordem natural das coisas, por transportarem a vida privada para o espaço público.

Dos depoimentos do Outro Distante foi possivel identificar a existência de generalizações e discriminação de diferentes ordens, as quais rotulam homens e mulheres vivendo em situação de rua como perigosos, sujos, reiterando a expressão utilizada por Nascimento, para quem a opinião pública os consideraria: "incômodos politicamente e perigosos socialmente" (Nascimento, 2000:81).

Daí termos observado, na análise do fenômeno, ao lado de manifestações de benemerência ocasional e violência explícita, a pertinência do que Simmel (2005) qualifica de caráter blasé, entendido como "embotamento" da percepção de muitos não moradores de rua frente a situação precária de vida de seres humanos que estariam, por assim dizer, "fora do lugar" e, por isso, segundo Escorel (2006), transgredindo um pilar da organização social que é a separação entre público e privado. Assim, de acordo com Simmel, interpretamos o morar na rua na perspectiva do não morador, o Outro Distante, como "discrepâncias" do meio exterior que no 
imaginário dos habitantes da cidade os "ameaçam". Consideramos a ocorrência do caráter blasé, em relação ao mesmo fenômeno, como significando a presença de uma invisibilidade protetora por parte do Outro Distante que transforma esse grupo sócio-populacional em "coisas", ou seja, em parte da paisagem deteriorada da cidade.

Esse olhar generalizador, discriminador e blasé do Outro Distante encontra ressonância igualmente nos olhares dos moradores de rua, homens e mulheres entrevistados, quando relatam o sentimento de serem desconsiderados como seres humanos e cidadãos, sentimento este identificado pela indiferença ("viram as costas e saem andando"), pela ausência de diálogo ("não falam nada"; "muitas pessoas nem na cara da gente olham... É como ver um cachorro sem dono e não estar nem aí), pela rotulação desqualificadora ("uns passam e tem nojo, outros passam e têm dó"), pelas diversas formas de violência - física e simbólica - ("esses indigentes, esses "sem teto"; "eles jogam muita coisa, cacos de garrafas...embaixo do viaduto em que eu estava. Jogam de propósito mesmo"; "o Rapa... eles batem na gente e levam as nossas coisas...").

Dessa forma, o discurso do Outro Distante apresenta, nos casos em que este "reconhece" a situação de rua para homens e mulheres, uma visão simplificada, estreita e reducionista por defini-los tão somente a partir do não pertencimento a uma "casa", esta entendida na sua dimensão material, na medida em que a vida na rua implica na vivência privada do cotidiano manifestada a céu aberto. Assim, tal simplificação parece levar o Outro Distante a perceber a população de rua como grupo homogêneo, indistinto, 
invisivel em suas peculiaridades, em suas necessidades, em suas diferenças.

Conforme observamos, uma das características dessa população é sua diversidade, fato já constatado em outros estudos, como o de Borin (2003), no Brasil, e o de Pais (2006), em Portugal. Essa percepção generalizadora, simplificadora e homogeneizadora desse grupo sóciopopulacional, leva à desqualificação de homens e mulheres pertencentes ao mesmo, como cidadãos, de acordo com narrativas em muitos dos depoimentos do Outro Distante. Diante disso, conforme referimos na introdução do presente trabalho, conceber essa população como um grupo de indivíduos desprovido de moradia representou uma primeira aproximação à análise do fenômeno e o reconhecimento de sujeitos sociais com trajetórias de vida específicas a serem entrevistados.

Em nossa interpretação, consideramos que homens e mulheres em situação de rua apresentam-se não somente como desprovidos de "residência fixa", reconhecidos como "sem teto", mas também, segundo Pais (2006:46), como indivíduos cuja rua representa o ponto de convergência entre origens e destinos diversos, em que o que os torna iguais é o não pertencimento a uma "casa" em seu sentido amplo. Esta, entendida na transcendência de sua materialidade representa, além da ausência de espaço físico - relatada por muitas mulheres investigadas em nosso trabalho - também e, sobretudo, o espaço da liberdade, da privacidade, da segurança, da existência de uma rotina doméstica por elas determinada. A casa representa ainda as possibilidades de relações, de um sentimento de 
pertencimento à sociedade, de conquista e preservação do que indivíduos, nessa situação, entendem como dignidade. A fala abaixo, de um dos sujeitos investigados por Alvarez (2003), com vários anos de vida na rua e passagem pelo Carandiru, apresenta-se como exemplar na caracterização do sentimento de dignidade associado à idéia de "casa", entendido, por nós, como a expressão legítima da busca de cidadania e inclusão social.

Segundo Alvarez (2003),

“Com lucidez, falou [Soviético, morador de rua] sobre dignidade:

- "Eu acho que dignidade é você chegar num lugar, tomar um banho sossegado, sentar numa cadeira... assistir uma bela de uma televisão, saber o que está acontecendo no mundo em geral... Quando todo mundo chegar: "Ôpa, faz favor, toma um cafezinho!..."

E voltando repentinamente à realidade de sua vida - nitidamente 'indigna', segundo seu conceito - continuou:

"As vezes a gente fica na maloca, e as vezes eu não quero beber e fico assim: "Puta! Vida careta! Ficá aqui é embaçado!" Às vez as mulher passa e fala: "Puxa! Aqueles cara todo forte, bonito, saudável!... Tudo maloqueiro!..." Aí eu abaixo a cabeça e até cubro a cabeça... e falo: "Que nada!... qué sabê de uma coisa? Eu vou encher a cara!" Aí eu encho a cara e fico normal, tranqüilo, sossegado... Só que eu não mexo com ninguém, também não roubo ninguém... Se for pra roubar eu roubo de quem tem. Quem não tem eu não quero nada disso! Sofri pra caramba!... E eu acho que dignidade é o homem tê uma casa, um ambiente... tê 
seu trabalho... tê sua ocupação, sua família... Isso é uma coisa mais feliz que tem no mundo. Mas do jeito que a gente vive, tá embaçado!..." (Alvarez, 2003:84-85)

Outro tipo de generalização decorrente da homogeneização desse grupo sócio-populacional é o não reconhecimento de uma dinâmica existente que o caracteriza na sua diversidade e nas suas relações com seus pares e demais cidadãos. Assim, como Pais, consideramos que essa diversidade não pode ser negligenciada porque "uns habituaram-se a viver na rua, tomando-a como moradia vitalícia, outros encaram a rua como pouso passageiro que esperam abandonar tão prontamente quanto possível" (Pais, 2006: 46).

Mais um aspecto relativo à importância de se considerar a diversidade desse grupo sócio-populacional encontra lugar quando observamos a diferenciação que os próprios indivíduos em situação de rua fazem entre si. Por fragmentos da fala de Afrodite, é possível caracterizar ao mesmo tempo o compartilhamento de uma situação específica de vida, em que ela se identifica como uma "moradora de rua", porém diferenciada em relação a muitos outros "moradores" na mesma condição:

Um dia que eu fui sem ele [amigo] para a igreja onde a gente sempre pedia alguma coisa para comer, uma pessoa da igreja chegou para mim e falou: _ "Olha, por que você não vem para a igreja sozinha?" Eu perguntei: "Por quê?" - "Porque você anda com esse tipo de gente e dá a impressão que você é igual". Naquele momento aquilo para mim doeu, porque eu vi que era igual. Eu respondi para essa pessoa: "Mas eu sou igual. Eu não 
tenho para onde ir. Eu não tenho dinheiro e estou assim pelos mesmos motivos dessa pessoa. "Eu percebi que não é bom, que não é fácil. Eu percebi que eles não vêem com bons olhos como eu também não vi um dia [...] Porque quando eu trabalhava e estudava e passava por algum lugar e via alguém na rua, eu sempre me perguntava: por que aquela pessoa estava ali? Eu imaginava: será que algum dia essa pessoa teve um lar? Será que ela teve um emprego? Será que essa pessoa quando atingiu a idade de andar e falar, jogaram na rua e ela está assim? Eu sempre me fazia essas perguntas. Então eu percebi que da mesma forma que aconteceu comigo acontece com as outras... Então eu ficava me perguntando - era uma curiosidade também que eu tinha, não é? Eu fazia todo aquele cenário: "Nossa, essa pessoa nunca teve uma casa? Como ela dorme embaixo de um viaduto ou no frio ou na chuva? Como consegue passar tantos dias sem tomar um banho? Então é uma coisa muito complexa..." (Afrodite, vivendo em albergue, 24 anos).

A seguir, observamos como Afrodite manifesta seu sentimento de diferenciação entre os que buscam o albergue como estilo ou modo de vida, daquele que o toma como um espaço de mediação entre a rua e a "casa":

"Porque o que eu observei aqui [no albergue] é que as pessoas que vêm para cá são pessoas que estão acostumadas a viver de esmolas. Este não é o meu caso, como eu já te falei, porque eu tive uma estrutura. Eu acho que falta um programa para essas pessoas que não receberam essa estrutura que eu tive, de terminar $o$ ensino médio, falta uma estrutura que reeduque essas pessoas para que elas possam voltar. Porque as 


\begin{abstract}
pessoas que vêm para cá - e me dou como exemplo disso, porque se não fosse tudo isso que eu já te falei, talvez eu me acostumasse também. Talvez eu falasse para você: "Eu quero passar seis meses aqui, seis meses em um outro e assim vou levando a minha vida", que é o acontece com os moradores de albergues" (Afrodite, vivendo em albergue, 24 anos).
\end{abstract}

Assim, no cruzamento de olhares do Outro Distante, do Outro Próximo e das mulheres em situação de rua, a percepção de não igualdade, de iniqüidade, representada a partir do que entendemos ser um sentimento ou manifestação discursiva do "nós" e dos "outros", encontra-se presente não somente em relação ao Outro Distante com homens e mulheres em situação de rua, mas também no interior desse grupo sócio-populacional, nas percepções que constroem sobre si. Dai para Afrodite, ela sentir-se ao mesmo tempo parte de uma população em situação de rua, mas diferenciada porque a rua, no seu caso, é referida como uma fase transitória e não permanente, como a entrevistada identifica ocorrer em casos de outros indivíduos, vivendo na rua e em albergues. Portanto, quando refletimos sobre as possibilidades de existência de um "modo de vida na rua", devemos considerá-lo na sua complexidade e diversidade.

Parte dessa complexidade e diferenciação revela-se nas questões de gênero que emergem dos relatos dos homens vivendo em situação de rua quando falam sobre as mulheres na mesma condição de maneira discriminatória. Para muitos deles, o espaço da rua não é o espaço da mulher e aquelas que lá estão, o fizeram por opção, lá estão por 
acomodação, por facilidades devido à suposta fragilidade feminina, sendo mais vulneráveis à "degeneração", pela prostituição e uso de drogas, manipuladas pela polícia, dentre outras implicações. Nesse aspecto, seus relatos vão ao encontro das narrativas do Outro Distante, o que passa a significar para a mulher uma dupla discriminação, de ambos os grupos. $\mathrm{Na}$ referida discriminação, sua desqualificação se dá por ser mulher e viver no mundo da rua, fora, portanto, do espaço da casa, do privado que, em nossa cultura, Ihe é atribuído como específico, segundo trabalho clássico de Da Matta (1987).

Embora presentes no discurso do Outro Distante, as questões de gênero ficam mais evidentes nos olhares cruzados de homens e mulheres vivendo em situação de rua. Este cruzamento é revelador de uma desigualdade entre homens e mulheres que, embora presente em nossa sociedade, acentua-se no cenário da rua porque nele não observamos traços indicativos da ampliação do campo de atuação feminina que caracteriza as últimas décadas no mundo contemporâneo, em termos de sua autonomia, possibilidades de negociações. Ao contrário, os relatos tanto de homens, como de mulheres apresentam o mundo da rua como um espaço de opressão, manipulação, violência em relação à mulher.

Tal fato se deve, ao que parece, por se tratar a rua de um locus predominantemente masculino, não só numericamente, mas igualmente em termos de regras e valores que cultural e socialmente norteiam a convivência de seus membros e grupos. A ordem patriarcal se revela, sobretudo pelas imagens socialmente sancionadas, já consideradas por nós, 
que identificam os homens como um "homem de verdade" se este for viril, provedor, ligado, portanto, ao mundo do trabalho, dentre outros aspectos. $\mathrm{Na}$ rua, desprovido dessas características generalizadoras de sua condição masculina, poderíamos entender, a partir de Nolasco (1997), que o homem exerceria a violência como forma de afirmação da virilidade - como expressão do poder masculino - e, também, a partir de Machado (2004), para o resgate de sua honra.

A violência masculina no mundo da rua, sob diferentes formas, é reconhecida tanto nos relatos do Outro Distante, como nas narrativas de homens e mulheres em situação de rua. As questões de gênero observadas, como as violências física, simbólica e sexual, o medo da relação afetiva, a dificuldade de inserção em grupos masculinos pela discriminação de idade, etnia e aparência física, dentre outras, redimensionam o lugar da mulher e suas relações nesse cenário, quando comparado àquele que as mesmas ocupam nas sociedades urbanas.

Uma hipótese explicativa para tal fato poderia ser relacionada à predominância de uma concepção de masculinidade e feminilidade observada nos discursos dos sujeitos entrevistados, que pode ser atribuída às forças opressoras do patriarcado, cujos traços ainda vigentes em nosso meio foram observados de maneira acentuada nos relatos dos três grupos entrevistados. Nas palavras de Saffioti, "se é verdade que a ordem patriarcal de gênero não opera sozinha, é também verdade que ela constitui o caldo de cultura no qual tem lugar a violência de gênero, a argamassa que edifica desigualdades várias, inclusive entre homens e mulheres" (Saffioti, 2002:1). 
Dentro da concepção presente nas falas dos entrevistados, os conceitos de masculino e feminino representam verdadeiros atributos da essência do que se entende por ser homem e ser mulher na sociedade como um todo, portanto, características naturalizadas, não socialmente construídas. Assim, atributos masculinos como heterossexualidade, poder, força física, coragem, agressividade são atribuídos aos homens, estes dotados da "capacidade natural", quer para proteger, quer para dominar o considerado "sexo frágil". Nessa perspectiva, a violência masculina e a opressão sobre a mulher são tidas como "naturais". Da mesma forma, tais atributos são valorizados entre os homens na naturalização de lideranças nos agrupamentos na rua, ao passo que resta àqueles que não as possuem, o estatuto de dominado ${ }^{24}$, tal qual acontece com as mulheres.

Masculinidade e feminilidade apresentam-se, nessa concepção, como categorias duais, polares, não pressupondo àquelas intermediárias, nem processos ${ }^{25}$. Diante disso, como contraponto aos atributos masculinos, os femininos caracterizar-se-iam por fragilidade física e mental, sensibilidade, passividade/submissão, reprodução biológica/maternidade natural, dentre outros...

Com tal visão de mundo, depreendida das narrativas apresentadas no decorrer desse trabalho, a violência, nas suas diferentes formas, torna-se marca identitária da masculinidade hegemônica, tanto para homens como para mulheres e, na dinâmica dessa polaridade, o homem seria visto como o

\footnotetext{
${ }^{24} \mathrm{Em}$ relação à questão considerada, da masculinidade hegemônica e subalterna ver, por exemplo, Da Matta (1997).

${ }^{25}$ Ver, a esse propósito, nota 10.
} 
protetor e/ou agressor e a mulher como vítima. Essa concepção de mulher como vítima e o homem opressor/protetor pode ser observada nas falas que recuperamos a seguir:

"Eu acho que tudo é dificil para a mulher. O homem se enfia em qualquer buraco, a mulher não. A mulher é mais frágil, mais delicada. A mulher na rua sofre mais do que o homem" (Héstia, vivendo em albergue, 37 anos).

"A mulher tem que se esconder em algum lugar e se aparar em algum amigo. O homem vem e quer se aproveitar da mulher. Comigo nunca aconteceu isto, porque eu tenho meus amigos aqui na rua. (os amigos) Me protegem, os meus me protegem. Não sei das outras, mas os meus me respeitam, me protegem. A mulher, se ficar sozinha na rua, os homens vêm e se aproveitam da mulher" (Éris, vivendo na rua, 50 anos)

"[A mulher] faz tudo por ele [o homem]. Trabalha para manter ele quando é uma mulher direita. Agora se for uma mulher vagabunda já era. Mas tem mulher sincera que chega e você é capaz de alugar um barraco em uma favela com ela que vai dar certo. Quando ela gosta de você dá certo, mas se for "nó-cega", não dá não" (Aquiles, vivendo em albergue, 49 anos).

Se considerarmos, no entanto, que tais atributos femininos, assim como os masculinos são diretamente associados a condutas sociais e culturais, podemos interpretar algumas falas de homens em relação às mulheres em situação de rua, norteadas por valores sócio-culturais tradicionais, a partir dos quais cabe a elas, no mundo da rua, reproduzirem o 
que Ihes é esperado no espaço da casa: tarefas "domésticas", ganhar dinheiro para sustentar/auxiliar o homem/protetor, manter fidelidade e obediência, "ser direita", enfim. Nesse tipo de expectativa de comportamento, a representação da mulher encontra-se reduzida e subalterna, desprovida de autonomia. Ignora-se, portanto, que tais diferenças não são inatas, naturais, mas resultantes de uma construção social, a qual permitiria à mulher repensar-se como sujeito histórico social, numa atualização constante, como observamos nas perspectivas de autoras como Scott, 1995; Azeredo e Stolcke, 1991, Heilborn, 2004 e Saffioti (1999; 2002; 2004; 2005) que partilham desta idéia independentemente das diferentes formulações teóricas adotadas pelas mesmas.

Diante disso, na busca de autonomia e poder que possa exercer frente ao conflito e à desigualdade de gênero na rua, a mulher é levada a incorporar valores e condutas características da masculinidade hegemônica, ou seja, na linguagem de Simmel (2001) submeter-se-ia a uma "formação dos homens", a qual segundo Bourdieu (2003), seria resultado da construção no imaginário feminino de diferentes formas inconscientes de percepção e apreciação segundo estruturas históricas de ordem masculina. Os depoimentos, abaixo retomados, são exemplos desta ordem:

"Para ela enturmar, vai ter que ser a mãezona de todos: vai ter que cozinhar...Tudo ali vai passar por ela. Outra coisa: eles também vão querer assumir o lado marido dela para poder ficar ali sem virar bagunça. Eles não vão respeitar ela. Eu conheço mulher que acabou virando lider da maloca por causa de fazer as coisas funcionarem. Mas a maioria das vezes não é assim...." 
((Orfeu, em situação de rua no período entre 2001 e 2003, 45 anos).

"É diferente [de homem, ser mulher na rua], mas elas usam da força braçal. Para morar na rua tem que encarar, então elas se defendem, se acham homem também" (Orestes, porteiro, 36 anos).

No mundo da rua, por se tratar de uma população que, embora heterogênea nos aspectos já apontados, se homogeneíza em função das precárias condições objetivas de existência, a despeito de mulheres e homens com diferentes graus de escolaridade e suas histórias de vida sinalizarem diferentes origens, pudemos observar a importância que as questões de gênero assumem no contexto pesquisado. Saffioti ao afirmar que gênero, classe e raça/etnia são eixos estruturantes da sociedade, considera:

\footnotetext{
"Dependendo das condições históricas vivenciadas, uma destas faces [gênero, classe ou etnia] estará proeminente, enquanto as demais, ainda que vivas, colocam-se à sombra da primeira. Em outras circunstâncias, será uma outra faceta a tornar-se dominante. Esta mobilidade do sujeito múltiplo acompanha a instabilidade dos processos sociais, sempre em ebulição" Saffioti (2004:79).
}

A questão de raça/etnia e classe no mundo da rua, embora não tenha sido proeminente na fala dos entrevistados, pode ser observada na fala de Orfeu: 


\begin{abstract}
"Eu acho que a mulher na rua sofre muito mais que o homem. Se ela for jovem, logo arruma alguém para proteger ela. Mas se for de mais idade, principalmente negra, ela é excluída... É moradora de rua... é negra... e se for idosa... três níveis de exclusão..." (Orfeu, em situação de rua no período entre 2001 e 2003, 45 anos).
\end{abstract}

Prosseguindo na interpretação, se em muitas situações pudemos observar as mulheres "jogando o jogo" masculino, ou se utilizando de sua "fragilidade" como estratégia de sobrevivência, é somente quando expressam seu sonho de ter uma "casa" - casa essa que é dela - é que pudemos desvelar que as mesmas falam do retorno ou (re)encontro de seu lugar no mundo, de sua identificação como sujeito histórico-social, uma vez que nessa casa sonhada não há menção à figura masculina.

Embora identifiquemos, em falas femininas do Outro Distante, que a saída das mulheres da rua se daria pela iniciativa das mesmas, pelo apoio familiar e ação do Estado, a posição do Outro Próximo parece manifestar de maneira explicita, a menção ao papel fundamental do homem para possibilitar a saída da mulher do mundo da rua, independentemente do recorte geracional:

"O futuro da mulher para sair da rua é só se ela achar um camarada bom, trabalhador, pode ser até ladrão. Se ele gostar dela e ela gostar dele é bom ela sair da rua. Pode morar até em baixo de uma ponte, é só os dois ficarem tranqüilos que acabou. Ou alugam um barraco e saem da rua, os dois se gostando não têm diferença do 
homem para a mulher (Aquiles, vivendo em albergue, 49 anos)

"Se a mulher não arrumar um emprego ou um marido, fica difícil. Porque mulher não quer saber de nada... só droga... na rua é só droga.." (Apolo, vivendo na rua, 25 anos).

"Em primeiro lugar eu acho que para as mulheres saírem a rua não tem como. A rua trás muita regalia. Muitas delas estão ganhando dinheiro para sustentar o seu vicio Muitas acham que a rua é diversão... Eu acho que não tem como tirar esse pessoal que vive na rua, a não ser que o povo parasse de dar esmola. Se ninguém desse nada a ninguém" (Adonis, vivendo em albergue, 23 anos)

Se Aquiles fala da casa pressupondo uma relação de conjugalidade, a casa sonhada por mulheres entrevistadas pode representar um contraponto, como salientamos anteriormente, ou seja, o simbólico, o não vivido, o desejado, o sonho de "segurança" e "fuga/saída", em oposição às experiências traumáticas sofridas por essas mulheres. É no sonho da casa que muitas mulheres em situação de rua parecem visualizar a superação de sua condição atual de vida e a conquista de autonomia, privacidade, dignidade e cidadania.

Assim, entendemos a importância que a categoria "casa" adquire como esperança de futuro, como um sentido a ser buscado para a vida de mulheres em situação de rua na busca do reencontro consigo mesmo. 
Nesses termos, tornam-se pertinentes as palavras de Bachelard quando afirma que:

"a casa é um corpo de imagens que dão ao homem razões ou ilusões de estabilidade [...] a casa é nosso canto do mundo [...] Sem ela, o homem seria um ser disperso. Ela mantém o homem através das tempestades do céu e das tempestades da vida. É corpo e é alma. [...] A casa abriga o devaneio, a casa protege o sonhador, a casa permite sonhar em paz. [...] Ao devaneio pertencem valores que marcam o homem [e a mulher] em sua profundidade". Conclui o autor, "a casa é uma das maiores (forças) de integração para os pensamentos, lembranças e sonhos do homem [e da mulher]" (Bachelard, 2005:26;36).

Tais asserções de Bachelard apresentam-nos bastante significativas considerando, que ao indagarmos sobre o sonho, as mulheres verbalizam a casa, e esta, na perspectiva do autor, assim como nas anteriormente referidas, faz com que ela não se sinta uma mulher simplesmente "sem teto', mas sim, sem um lugar no qual se realizar como ser humano e dar sentido a sua vida.

Como pudemos demonstrar, ao tomarmos como objeto de reflexão a mulher em situação de rua, deparamo-nos com fenômeno imbricado que requer para sua compreensão não somente os discursos da mesma sobre sua condição, mas também um entrecruzar de olhares dos vários sujeitos envolvidos no cotidiano de suas relações, em que a dimensão microssocial adquire sentido. No entanto, não basta permanecermos nessa dimensão, na medida em que constatamos que o referido fenômeno envolve 
necessariamente a consideração conjunta de determinantes micro e macrossociais para que os mesmos se expressem na sua inteireza, nos cenários, - em que histórias de vida se concretizam e se entrelaçam - e não se descole de contextos sociais mais amplos.

Finalmente, pensar a questão do morar na rua não é reduzir homens e mulheres a uma situação de pura exclusão em função das condições objetivas de existência, mas, além disso, é preciso considerá-los, a partir de uma perspectiva que os contemple simultaneamente, destituídos de condições mínimas de existência material e com possibilidades precárias para o resgate do sentido de suas existências. 


\section{REFERÊNCIAS}

ALMEIDA, M.I.M. Masculino/feminino: tensão insolúvel: sociedade brasileira e organização da subjetividade. Rio de Janeiro: Rocco, 1996.

ALVAREZ A. M. S. A resiliência e o morar na rua: estudo com moradores de rua - criança e adultos - na cidade de São Paulo. 1999. 198 p. Dissertação [Mestrado] - Faculdade de Saúde Pública, Universidade de São Paulo, São Paulo, 1999.

ALVAREZ, A. M. S. Resiliência e encontro transformador em moradores de rua na cidade de São Paulo. 2003. [314] p. Tese [Doutorado]. - Faculdade de Saúde Pública, Universidade de São Paulo, São Paulo, 2003.

ARAÚJO, C. Marxismo, feminismo e enfoque de gênero. Crítica marxista 2000, (11):65-70.

AZERÊDO, S.; STOLCKE, V. Direitos reprodutivos. São Paulo: Fundação Carlos Chagas/DPE, 1991, p. 73-88.

BACHELARD, G. A poética do espaço. São Paulo: Martins Fontes, 2005. $242 \mathrm{p}$.

BORIN, M.E.S. Desigualdades e rupturas sociais na metrópole: os moradores de rua em São Paulo. . 2003. Tese [Doutorado] - Pontifícia Universidade Católica de São Paulo, São Paulo, 2003. 
BOURDIEU, P. A dominação masculina. Rio de Janeiro: Bertrand Brasil, 2003.

BOURDIEU, P. et al. A miséria do mundo.Petrópolis, RJ: Vozes, 2007.

BOURDIEU, P. Razões práticas sobre a teoria da ação. Campinas: Papirus, 2005.

BOURDIEU, P.; PASSERON, J. C. A reprodução: elementos para uma teoria do sistema de ensino. Rio de Janeiro: Francisco Alves, 1975.

BURSZTYN, M. Da utopia à exclusão: vivendo nas ruas em Brasília. Petrópolis: Vozes, 1997.

BURSZTYN, M. No meio da rua: nômades, excluídos e viradores. Rio de Janeiro: Garamond, 2000.

BUTLER, J. Problemas de gênero: feminismo e subversão da identidade. Rio de Janeiro: Civilização. Brasileira, 2003.

CASTEL, R. De l'indigence à l'exclusion, la désaffiliation: précarieté du travail et vulnerabilité relationnelle. In: Donzelot, J.; Roman, J. Face á l' exclusion: le modele français, Paris: Esprit, 1991. p. 137-168.

CASTEL, R. Les marginaux dans I'histoire. In: PAUGAM, S. (org.). L'exclusion: l'etat des saviors. Paris: Éditions La découvert, 1996. p. 32-41. 
DA MATTA, R. A casa e a rua: espaço, cidadania, mulher e morte no Brasil. São Paulo: Brasiliense, 1987.

DA MATTA, R. Tem pente ai? Reflexões sobre a identidade masculina. In: CALDAS, Dário (org.). Homens: comportamento, sexualidade e mudança. São Paulo: Senac, 1997. p. 31-49.

DEAN, R.; CRAIG, T. Pressure points: why people with mental health problems become homeless. Londres: Crisis, 1999.

DECLERCK, P. Le naufragés: avec les clochards de Paris. Paris: Plon, 2001.

Disponível em: <http//www.crisis.org.uk>. Acesso em: 22 maio 2007.

Disponível em:

<http://www.scielo.br/scielo.php?script=sci_arttextepid=S0104-

93132005000200010elng=enenrm=iso>. Acesso em: 27out. 2006.

DOUGLAS, Mary. Pureza e perigo. São Paulo: Perspectiva, 1976.

ELIAS, N. A sociedade dos indivíduos. Rio de Janeiro: Jorge Zahar Ed., 1994.

ESCOREL, S. Vidas ao léu: trajetórias de exclusão social. Rio de Janeiro: Fiocruz, 2006. 
FONSECA, C. Concepção de família e práticas de intervenção: uma contribuição antropológica. Saúde e sociedade, São Paulo, v. 14, n. 2, p. 5059, maio-ago. 2005.

FONSECA, C. Fofoca e honra. Porto Alegre: Ed. UFRGS, 2000.

GEOFREY, R.; BROWN, S. Trouble at home: family conflict, young people and homelessness. Londres: Crisis publications, 2001. Disponivel em: <http//www.crisis.org.uk>. Acesso em: 22 maio 2007.

GIDDENS, A. A transformação da intimidade: sexualidade, amor e erotismo nas sociedades modernas. São Paulo: Unesp, 1993.

GIORGETTI, C. Morador de rua: uma questão social? São Paulo: Editora Puc-SP: Fapesp, 2006.

GOFFMAN, E. Estigma: notas sobre a manipulação da identidade deteriorada. São Paulo: LTC, 1998.

GORTON, S. Homeless young women and pregnancy: pregnancy in hostels for single homeless people. Londres: Crisis, 2000. Disponível em: <http//www.crisis.org.uk>. Acesso em: 22 maio 2007.

GREGORI, M.F. Cenas e queixas: um estudo sobre mulheres, relações violentas e a prática feminista. São Paulo, Paz e Terra/ANPOCs, 1993.

HEILBORN, M. L. (2004) - Dois é par. gênero e identidade em contexto igualitário. Rio de Janeiro:Garamond. 
IANNI, O. A era do globalismo. Rio de Janeiro: Civilização Brasileira, 1997.

ITABORAÍ, N. R. A proteção social da família brasileira contemporânea: reflexões sobre a dimensão simbólica das políticas públicas. 2005. 18p. In: SEMINÁRIO "AS FAMÍLIAS E AS POLÍTICAS PÚBLICAS NO BRASIL", 2005, Belo Horizonte. Anais... Campinas: ABEP, 2005. Disponível em: <http://www.abep.nepo.unicamp.br/docs/anais/outros/FamPolPublicas/Natha lieltaborai.pdf>. Acesso em: 17 jan. 2008.

JELIN, E. Las familias em América Latina. Ediciones de las mujeres, Santiago, n. 20, p. 75-106, 1994.

JONES, A. Out of sight out of mind? The experiences of homeless women. Londres: Crisis, 1999.

LIEBOW, E. Tell them who I am: the lives of homeless womem. Nova lorque: Penguin, 1993.

LIMA, M. E. A. T. Análise do discurso e/ou análise de conteúdo. Psicologia em revista, Belo Horizonte, v. 9, n. 13, p.76-88, jun. 2003.

LOURO, G. L. Epistemologia feminista e teorização social: desafios, subversões e alianças. In: ADELMAN,M.; SILVESTRIN. C.B. (orgs). Gênero plural. Curitiba, UFPR, 2002. p. 11-22. 
MACHADO, L. Z. Masculinidade e violências: gênero e mal estar na sociedade contemporânea. In: SCHPUN, M. R. (org). Masculinidades. São Paulo: Boitempo; Santa Cruz do Sul: Edunisc, 2004. p. 35-78.

MAGNANI, J. G. C. Rua: símbolo e suporte da experiência urbana. [on-line] Disponível em: <http://www.n-a-u.org/ruasimboloesuporte.html>. Acesso em: 14 out. 2007. (Versão atualizada e ampliada de "A rua e a evolução da sociabilidade", originalmente publicado em Cadernos de História de São Paulo, São Paulo, n. 2, jan.-dez. 1993.).

MAGNANI, J.G.C. (2002). De perto e de dentro: notas para uma etnografia urbana. Rev. Brasileira de Ciências Sociais, São Paulo, v. 17, n. 49, p. 1129, jun. 2002.

MARTINEZ, A. S.; MOYA, J. M.; MUNÕZ, M. A. D. Mujeres, espacio y sociedad: hacia una geografía del género. Madrid: Editorial Síntesis, 1995.

MARTINS, J. S. Exclusão social e a nova desigualdade. São Paulo: Paulus, 1997.

MEYHI, J. C. S. Manual de história oral. Edições Loyola: São Paulo, 1998.

MILOVIC, M. et al. Sociedade e diferença. Brasília: Casa das Musas, 2005.

MINAYO, M. C. S. O desafio do conhecimento: pesquisa qualitativa em saúde. São Paulo: Hucitec/Abrasco, 1992. 
NASCIMENTO, E.P. Dos excluídos necessários aos excluídos desnecessários. In: BURSZTYN, M. No meio da rua: nômades, excluídos e viradores. Rio de Janeiro: Garamond, 2000. p. 56-87.

NASCIMENTO, E.P. Globalização e exclusão social: fenômenos de uma nova crise da modernidade? In: DOWBOR, L.; IANNI, O.; RESENDE, P.E.A. Desafios da globalização. Petrópolis: Vozes, 1997. p. 74-94.

NASCIMENTO, P.F.G. Ser homem ou nada: diversidade de experiências e estratégias de atualização da masculinidade hegemônica em Camaragibe/PE., 1999. Dissertação [Mestrado], UFPE, Recife 1999.).

NASSER, A. C. A. Sair para o mundo: trabalho, família e lazer na vida dos excluídos. São Paulo: Hucitec, 2001.

NOLASCO, S. A. Um homem de verdade. In: CALDAS, D. (org.): Homens: comportamento, sexualidade e mudança. São Paulo: Senac, 1997. p. 13-29.

NOVAC, S.; BROWN, J.; BOURBONNAIS, C. No room of her own: a literature review on women and homelessness. Ottawa: Centre Canadien de Documentation sur l'Habitation, 1996. Disponivel em: <http://www.ginsler.com/documents/noroom.pdf>. Acesso em: 12 mar. 2008.

NYAMATHI A. et al. Motivation to stop substance use and psychological and environmental characteristics of homeless women. Addictive Behaviors. V. 29, I. 9, Dec.2004, p. $1839-1843$. 
OLIVEIRA, M.C. A família brasileira no limiar do ano 2000. Estudos feministas, Florianópolis, v. 4, n. 1, p. 55-63, 1996.

OLIVEIRA, P. P. A construção social da masculinidade. Belo Horizonte: UFMG, 2004.

ORTEGA Y GASSET, J. Em torno a Galileu: um esquema das crises. Petrópolis: Vozes, 1989.

PAIS, J. M. Nos rastos da solidão: deambulações sociológicas. Porto: Âmbar, 2006.

PASSARO, J. The persistence of homelessness: reflections on gender, class and race. International Journal of Narrative Therapy and Community Work, Adelaide, n .3, p. 45-49, 1999.

PAUGAM, S. La desqualification sociale: essai sur la novelle pauvreté. Paris: PUF, 1993.

PHELAN, J. et al. The stigma of homelessness: the impact of the label "homeless" on attitudes towards poor persons. Social Psychology Quarterly, Washington, v. 60, n. 4, p. 323-337, Dec. 1997.

PIERRET, J. Elementos para reflexão sobre o lugar e o sentido da sexualidade na sociologia. In: LOYOLA M. A. (org.) A sexualidade nas ciências humanas. Rio de Janeiro: Editora da UERJ, 1998. p. 49-68. 
POCHMANN, M. Outra cidade é possivel: alternativas de inclusão social em São Paulo. São Paulo: Cortez, 2003.

QUEIROZ, M. I. P. Relatos orais: do dizivel ao indizível. In: Von Simson, O. R. M. (org). Experimentos com histórias de vida: Itália-Brasil. São Paulo: Vértice, 1988.

QUINTAS, F. A mulher e a família no final do século XX. Recife: Editora Massangana, 2005.

RAMIREZ, R. Ideologías masculinas: sexualidade e poder. In: NOLASCO, S. A. (org). A desconstrução do masculino. Rio de Janeiro: Rocco, 1995. p. 7582.

REEVE, K. et al. (2006) Homeless Women: Still being Failed yet Striving to Survive. London, Crisis.

REITER, R. R. Toward to an anthropology of women. Nova lorque: Monthly Review Press, 1975.

ROBERTSON, M. J. Homeless women with children: the role of alcohol and other drug abuse. American Psychologist, Washington, v. 46, n. 11, p. 11981204, Nov. 1991.

ROCHA, D.; DEUSDARÁ, B. Análise de conteúdo e análise de discurso: aproximações e afastamento na (re)construção de uma trajetória. Alea, Rio de Janeiro, v. 7, n. 2, p. 305-322, jul.-dez. 2005. 
ROWLES, G. The meaning of home in rural America. lowa: Joseph L. Parkin Memorial Lecture on Aging. University of lowa, 2006. Disponivel em: $<$ <ttp://www.centeronaging.uiowa.edu/WhatWeDo/TheMeaningofHomeinRur alAmerica.pdf>. Acesso em: 18 out. 2007.

SAFFIOTI, H. I. B. Contribuições feministas para o estudo da violência de gênero. Labrys, Estudos Feministas, n. 1-2, jul.-dez., 2002.

SAFFIOTI, H. I. B. Gênero e patriarcado. In: CASTILLO-MARTIN, M.; OLIVEIRA, S. (orgs.). Marcadas a ferro: violência contra a mulher - uma visão multidisciplinar. Brasília: Secretaria Especial de Políticas para as mulheres, 2005. p. 35-76.

SAFFIOTI, H. I. B. Gênero, patriarcado e violência. São Paulo: Fundação Perseu Abramo, 2004.

SAFFIOTI, H. I. B. Já se mete a colher em briga de marido e mulher. São Paulo em Perspectiva n. 13: 82-91,1999.

SAFFIOTI, H. I. B. O Poder do Macho. São Paulo, Moderna, 1987.

SAMPAIO, L. A.; ROSSI, P. D. A condição de estranho nas relações cotidianas. In: MARTINS, J. S. (org) - Vergonha e decoro na vida cotidiana da metrópole. São Paulo: Hucitec, 1999.

SARTI, C. A familia como espelho: um estudo sobre a moral dos pobres. São Paulo: Autores Associados, 1996. 
SCOTT, J. Gênero: uma categoria útil para a análise histórica. Educação e Realidade, Porto Alegre, v. 20, n. 2, p. 71-99, 1995.

SIMMEL, G. A cultura feminina. In: Filosofia do amor. 2. ed. São Paulo: Martins Fontes, 2001.

SIMMEL, G. As grandes cidades e a vida do espírito. Mana, Rio de Janeiro, v. 11, n. $2,2005$.

SIMMEL, G. O estrangeiro. In: MORAES FILHO, E. Simmel. São Paulo, Ática, 1983.

SIMMEL, G. The Poor. In: Levine, D. (org.). Georg Simmel, on individuality and social forms: selected writings. Chicago: The University of Chicago Press, 1971.

SINGLY, F. A sociologia da família contemporânea. Rio de Janeiro: Editora FGV, 2007.

SNOW, D.; ANDERSON, L. Desafortunados: um estudo sobre o povo da rua. Petrópolis: Vozes, 1998.

SOMERVILLE, P. Homelessness and the meaning of home: rooflessness and rootlessness? International Journal of Urban and Regional Research, London, v. 16, n. 4, p. 529-539, 1992. 
SOUZAS, R.; ALVARENGA, A.T. Da negociação às estratégias: relações conjugais e de gênero no discurso de mulheres de baixa renda em São Paulo. Saúde e Sociedade, São Paulo, v. 10, n. 2, p. 15-34, 2001.

THOMAS, A.; DITTMAR, H. The experience of homeless womem: an exploration of housing histories and the meaning of home. Housing studies, Bristol, v. 10, n. 4, p. 493-515, 1995.

TOURAINE, A. Face à l' exclusion. In: BAUDRILLARD J. Citoyenneté et urbanité. Paris: Esprit, 1991.

TOURAINE, A. Iguais e diferentes: poderemos viver juntos? Lisboa: Instituto Piaget, 1997.

VARANDA, W. V. Do direito a vida à vida como direito: sobrevivência, intervenções e saúde de adultos destituídos de moradia nas ruas da cidade de São Paulo. 2003. [125] p. Dissertação [Mestrado] - Faculdade de Saúde Pública, Universidade de São Paulo. São Paulo, 2003.

VELHO, G. Família e subjetividade. In: Almeida, A. M. et al. (org). Pensando a familia no Brasil: da colônia à modernidade. Rio de Janeiro: UFRRJ, 1987b. p. $79-88$.

VELHO, G. Individualismo e cultura: notas para uma Antropologia da Sociedade Contemporânea. Rio de Janeiro: Jorge Zahar, 1987a. 
VELHO, G. O estilo de vida urbano. Estudos históricos, Rio de Janeiro, v. 8, n. 16, p. $227-234,1995$.

VELHO, G. Subjetividade e sociedade: uma experiência de geração. Rio de Janeiro: Jorge Zahar, 1986.

VíctoRA, C. G. et al. Pesquisa qualitativa em saúde: uma introdução ao tema. Porto Alegre: Tomo Editorial, 1990.

VIEIRA, M. A. C.; RAMOS BEZERRA, E. M.; MAFFEI ROSA, C. M. População de rua: quem é, como vive, como é vista. São Paulo: HUCITEC, 2004.

VILLELA, W. V e BARBOSA, R. M. Repensando as relações entre gênero e sexualidade in Parker, R.; Barbosa, R. (orgs.). Sexualidades brasileiras. Rio de Janeiro: Relume-Dumará, 1996. p. 189-199 .

WARDHAUGH, J. The unaccommodated woman: home, homelessness and identity. Sociological Review, Keele, v. 47, n. 1, p. 91-109, 1999. 


\section{ANEXO 1}

\section{Roteiros temáticos:}

\section{Grupo 1 - o Outro Distante}

1. Nome fictício por parte do(a) entrevistado(a).

2. Idade e ocupação.

3. Morador de rua como categoria:

a) Quem são os moradores de rua?

b) Por que v. acha que eles estão aí?

4. Percepção da mulher em situação rua

a) Como devem viver mulheres em situação de rua?

5. O "morar na rua" para homens e mulheres

a) existem diferenças na vivência de ambos a partir da mesma experiência?

6. Motivos que levam à rua

a) que motivos levariam uma mulher a viver na rua? Serão motivos diferentes dos que levariam homens a mesma situação?

7. Cotidiano

a) Que problemas a mulher em situação enfrenta no seu dia a dia?

8. O que v. faz se estiver andando e encontrar mulheres em situação de rua na calçada ou mesmo andando?

9. Já observou como é o comportamento das pessoas? Já viu um transeunte (ou policial, ou comerciante, etc...) maltratar moradores de rua? O que aconteceu?

10. Quanto ao futuro, como vê possibilidades para essa mulher deixar a rua? 


\section{Grupo 2 - 0 Outro Próximo}

2. Escolha do nome fictício

3. Idade. Tempo na rua.

4. Que motivos levam mulheres a viver na rua?

5. Que motivos que levam homens a viver na rua?

6. Mulher na rua: como é a vida de uma mulher na rua?

7. Homem na rua: como é a vida de um homem na rua?

8. Que problemas diferentes dos homens, as mulheres enfrentam no cotidiano da rua?

9. Relações de gênero: como são os relacionamentos entre homens e mulheres quando ambos vivem em situação de rua?

10. E se houvesse uma casa, seria diferente? Em que?

11. Existem grupos só de mulheres na rua?

12. Como uma mulher é aceita em um grupo na rua? (reconhecimento do "código" de inserção nos grupos).

13. Que atividades as mulheres realizam na rua? Elas auxiliam os homens? Como?

13. Como as pessoas "de fora" (técnicos, policiais e transeuntes) tratam o morador de rua?

14. Existe diferença no tratamento de mulheres e homens? Conte-me um episodio que $v$ relembre.

15. Quanto ao futuro, como vê possibilidades para essa mulher deixar a rua? 


\section{Grupo 3 - Mulheres em situação de rua}

1- Escolha do nome fictício.

2- Idade.

3- Busca de espaços seguros: dormir na rua ou albergues? Por quê? Participação em programas assistenciais ou não: motivos da adesão ou não adesão.

a. Mulheres em albergues:

- Já viveu na rua? Por quanto tempo?

- Por que v. resolveu procurar este albergue/casa?

- O que $v$ acha do lugar em que está agora? (pontos positivos e negativos..) Por que?

- Como v. gostaria que fosse um albergue?

- O que v. pediria à prefeitura?

b. Mulheres na rua

- Há quanto tempo v. está na rua?

- Já procurou algum albergue ou equipamento oferecido pela prefeitura? Por que não ficou / Por que não procurou?

- Como v. gostaria que fosse um albergue?

- O que v. pediria à prefeitura?

4- Origens familiares, relacionamento com a família de origem.

a. Como era sua família? (pai, mãe, irmãos, padrasto, madrasta...)

b. Como foi sua infância? Como foi sua adolescência?

c. Como v. caracterizaria seu relacionamento familiar?

5- A trajetória para a rua; opção pela rua e motivos explicitados.

a. Como v. foi para a rua?Por que?

b. Existe diferença entre ser mulher e ser homem na rua?

c. Quando v. foi para rua, lembre-se de como passou sua primeira noite.

d. Como se aproximou de outros moradores de rua?

e. Existem grupos de mulheres? 
6- O cotidiano (vivência de um dia): utilização dos equipamentos institucionais e as 24 horas na rua.

a. Como v. começa o seu dia?

b. Como divide o seu dia?

c. Que atividades realiza durante o dia?

d. Como v. controla o tempo na rua? (para mulheres na rua)

e. Quantas refeições faz por dia?

f. Qual é o lazer de quem vive na rua?

g. Que coisas v. não gosta da vida na rua?

h. Que coisas v. gosta na rua?

i. O que significa a rua para $v$ ?

j. Conte-me como moradores de rua se ajudam entre si?

7- Religião, amigos e pontos de apoio: quem me ajuda? Com quem me relaciono?

a) Quem mais te ajudou até agora?

b) $V$. tem amigos na rua? O que eles fazem por v.?

c) $\mathrm{E}$ as amizades antigas, de antes da rua?

d) V.é uma pessoa religiosa?

e) $V$. recebe apoio de usa religião? Como?

8- Saúde física e mental: como vivencio minha relação com meu corpo (menstruação, gravidez, maternidade)?

a. Como v. faz quando menstrua aqui na rua? (para mulheres na rua)

b. Já engravidou quantas vezes?

c. Seus filhos nasceram na rua?

d. V. vai ao médico com que freqüência?

e. Qual a ultima vez que foi ao médico? Por que?

f. V. toma anticoncepcionais? 
9- Espaço da intimidade: "meu lar", minha familia, meu companheiro(a), meus filhos. Como vivencio minha sexualidade?

a. V. tem um namorado ou companheiro?

b. Como é o namoro na rua?

c. Existe diferença entre namorar na rua e em, casa?

d. Como v. transa com seu namorado ?Aqui na rua? Onde?

e. Como v. definiria o que é um relacionamento a dois na rua e em casa?

f. Se v. tivesse uma casa, o que mudaria?

g. O que significa "casa" para você?

10- Nós e os outros; sentimentos de inclusão e exclusão, reconhecimento das diferenças de gênero - o ser homem e o ser mulher vivendo em situação de rua.

a. Como as pessoas que passam na rua tratam (ou trataram) você? O que v. ouve (ou ouvia)?

b. E os homens com quem você convive: o que ouvem dos que passam (ou passaram) por vocês?

c. Conte-me um pouco sobre quais as dificuldades e facilidades de ser mulher na rua?

d. É diferente para os homens?

11- Resistência e participação: como penso minha cidade, meu país, meu mundo;

a. Na sua opinião, por que existem pessoas morando na rua?

b. O que você gostaria que acontecesse?

c. V. imagina como vivem as pessoas em situação de rua em outros países? O que será que muda?

12- Sentido da vida, projetos de vida. Existe esperança?

a. Qual seu maior sonho?

b. Como v. se imagina daqui a um mês? Daqui a seis meses? Daqui a um ano? Daqui a três anos?

c. Qual seu objetivo na vida?

d. Qual seu maior sonho? 


\begin{abstract}
ANEXO 2
Anotações de campo

\author{
Universidade de São Paulo \\ Faculdade de Saúde Pública - Departamento Materno-Infantil
}

Olhares entrecruzados: mulheres em situação de rua na cidade de São Paulo

Entrevistador:

Data: / $/ 2007$

\title{
Anotações de Campo
}

1. Cenário

a) Localização e caracterização detalhada do local em que se encontra o entrevistado (albergue, rua; condições físicas - luminosidade, isolamento, visual-....);

b) Caracterização do grupo: Quem mora? (quantos vivem juntos, número de homens e mulheres, presença de crianças, relações existentes entre os membros do grupo);

c) Descrição do cenário (como vivem os entrevistados?) - onde dormem, organização do local, móveis e objetos pessoais, enfeites, utensílios de cozinha, odores, sons...

d) Tempo de permanência no local;

e) Reconhecimento do entorno: vizinhança - quem é, que relações estabelece-;

2. Impressões do entrevistador

a) Abordagem:

b) Percepção sobre o entrevistado: como foi a postura do entrevistado? Olhares, gestos, comportamento...

c) Entrevista: como transcorreu a entrevista? 
d) Ocorrência de fatos relevantes durante a entrevista, como discussões, choro...

e) Anotações da experiência de campo: impressões do entrevistador 


\section{Anexo 3 \\ TERMO DE CONSENTIMENTO LIVRE E ESCLARECIDO \\ "O respeito devido à dignidade humana exige que toda pesquisa se processe após consentimento livre e esclarecido dos sujeitos, indivíduos ou grupos que por si e/ou por seus representantes legais manifestem a sua anuência à participação na pesquisa." (Resolução. $\mathrm{n}^{\circ}$ 196/96-IV, do Conselho Nacional de Saúde)}

Fui informado(a) a respeito da presente pesquisa, intitulada "Olhares entrecruzados: mulheres em situação de rua na cidade de São Paulo", sob responsabilidade da aluna Gisele Aparecida Dias Franco Arrunátegui, orientada pela Profa. Dra. Augusta Thereza de Alvarenga, da Faculdade de Saúde Pública da Universidade de São Paulo.

Após ser convidado(a) a participar da referida pesquisa, tive a explicação que minha participação consistirá na concessão de entrevistas gravadas. Ao responder as questões propostas nas tais entrevistas, estarei colaborando para um estudo de cunho acadêmico, que tem como objetivo compreender a experiência do morar na rua pela perspectiva das mulheres, desvelando ainda como as mesmas são vistas pelos outros (estes em situação de rua ou não).

Responderei perguntas sobre minha vida pessoal e/ou minhas opiniões acerca da mulher em situação de rua, podendo decidir responder ou não quaisquer questões e interromper a entrevista sem punição por isso.

Fui também informado(a) que as entrevistas serão identificadas por número e posteriormente por um nome fictício, escolhido por mim, a fim de que meu nome verdadeiro JAMAIS seja mencionado quando forem apresentados os resultados da pesquisa.

Estou garantido(a) que poderei desistir de participar da pesquisa a qualquer momento, inclusive sem nenhum motivo, bastando para isso, informar minha decisão de desistência, da maneira mais conveniente. Fui esclarecido(a) ainda que, por ser uma participação voluntária e sem interesse financeiro, não terei direito a nenhuma remuneração. A participação na pesquisa não incorrerá em riscos ou prejuízos de qualquer natureza.

Se eu estiver de acordo em participar, assinarei, juntamente com a pesquisadora responsável, este Termo de Consentimento Livre e Esclarecido. Caso eu prefira não assinar, porque não quero, nem aqui neste termo, registrar minha identidade, minha decisão será respeitada e poderei, mesmo assim, participar da pesquisa. 
Declaro que recebi as informações que solicitei sobre a pesquisa, bem como que este termo foi lido junto comigo, de maneira que decido participar de forma livre e esclarecida.

São Paulo, ..... de de 2007.

Assinatura do participante:

Assinatura da pesquisadora:

Gisele Aparecida Dias Franco Arrunátegui

Para contato: tels. 30812451/30667703/ 30667703 (Departamento de Saúde Materno-infantil - Faculdade de Saúde Pública/ USP). 